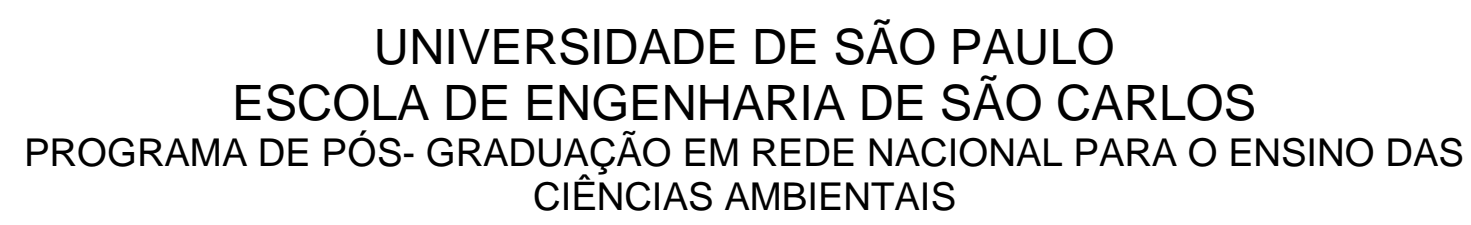

CIÊNCIAS AMBIENTAIS

ANÁLISE AMBIENTAL HISTÓRICA E ATUAL DOS CÓRREGOS DO MUNICÍPIO DE SÃO CARLOS, SP

"versão corrigida"

SÃO CARLOS

2020 



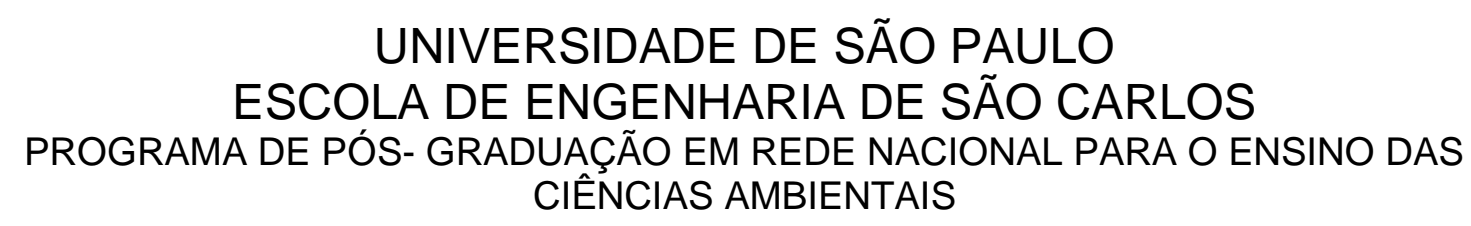

\section{ANÁLISE AMBIENTAL HISTÓRICA E ATUAL DOS CÓRREGOS DO MUNICÍPIO DE SÃO CARLOS, SP}

Adriano Remorini Tralback

Orientador: Prof. Dr. Juliano José Corbi

Dissertação apresentada a Escola de Engenharia de São Carlos - EESC-USP, como parte dos requisitos para obtenção do título de Mestre em Ciências - área de concentração: Ensino das Ciências Ambientais.

SÃO CARLOS

2020 


\section{AUTORIZO A REPRODUÇ̃̃O TOTAL OU PARCIAL DESTE TRABA- LHO, POR QUALQUER MEIO CONVENCIONAL OU ELETRÔNICO, PARA FINS DE ESTUDO E PESQUISA, DESDE QUE CITADA A FONTE.}

Ficha catalográfica elaborada pela Biblioteca Prof. Dr. Sérgio Rodrigues Fontes da EESC/USP com os dados inseridos pelo(a) autor(a).

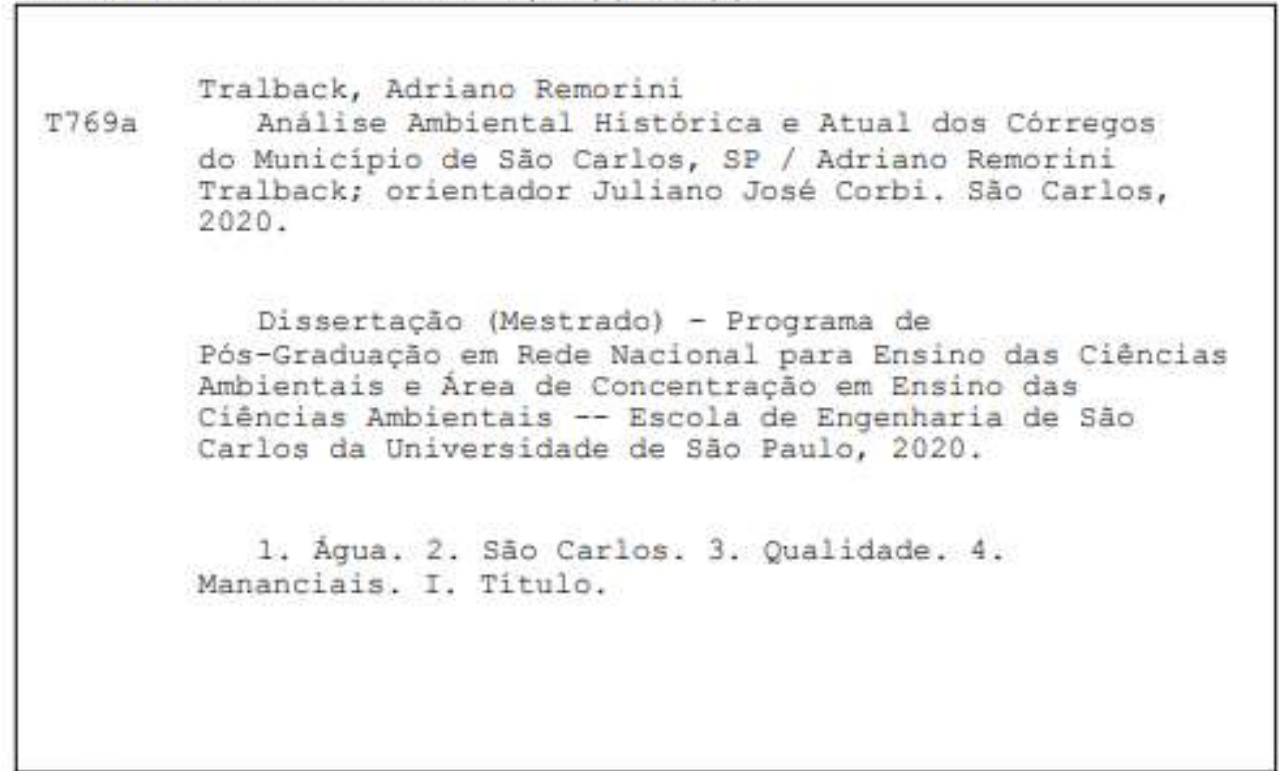

Eduardo Graziosi Silva - CRB - 8/8907 


\section{FOLHA DE JULGAMENTO}

Candidato: Bacharel e Licenciado ADRIANO REMORINI TRALBACK.

Título da dissertação: " Análise ambiental histórica e atual dos córregos do município de São Carlos, SP".

Data da defesa: 10/07/2020.

Comissão Julgadora:

Prof. Associado Juliano José Corbi

(Orientador)

(Escola de Engenharia de São Carlos/EESC-USP)

Prof. Dr. Fernando Periotto

(Universidade Federal de São Carlos/UFSCar)

Profa. Dra. Ione Arsenio da Silva

(Instituto Federal de Educação, Ciência e Tecnologia de São Paulo/IFSP-

Campos do Jordão)

Coordenador do Programa de Pós-Graduação em Rede Nacional para Ensino das Ciências Ambientais:

Prof. Associado Juliano José Corbi

Presidente da Comissão de Pós-Graduação:

Prof. Titular Murilo Araujo Romero
Resultado:

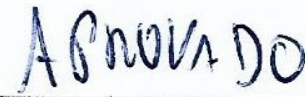

AproUnAo

AphoVADO 
No meio da dificuldade encontra-se a oportunidade.

Albert Einstein 


\section{AGRADECIMENTOS}

Agradeço a todos que durante esta ávida jornada de estudo e pesquisa ajudaram na conclusão do trabalho.

Em primeiro lugar gostaria de agradecer meu orientador, o Professor Doutor Juliano José Corbi, o qual além de ser meu orientador foi um de meus Professores do Curso de Graduação de Licenciatura em Ciências, da USP/UNIVESP, Polo São Carlos, o qual sempre nos incentivou nos estudos envolvendo todas as disciplinas e continuou incentivando muito na corrente pesquisa relativa a esta Dissertação do Mestrado.

Agradeço também todos os familiares, em especial minha companheira do dia-a-dia

a Professora Andréa Simone da Silva a quem sempre me incentivou muito em todos os meus caminhos e minhas jornadas.

Também não posso deixar de agradecer todos os Professores das disciplinas deste Curso de Mestrado Profissional em Ciências Ambientais bem como meus colegas que não são mais colegas, mas sim amigos que me acompanharam durante todo o curso. Por fim, espero devolver a Sociedade de forma útil e plena todos os conhecimentos que me foram passados, para o bem da Ciência e do Meio Ambiente para que com isso possa manter vivos os princípios da educação ambiental, sustentabilidade, reciclagem de materiais e preservação do meio ambiente sem os quais o homem jamais poderá abrir mão, para que seja garantido o direito de usufruir de um meio ambiente preservado e ecologicamente equilibrado pelas futuras gerações. 
Não tentes ser bem-sucedido, tenta antes ser um homem de valor.

Albert Einstein 


\section{RESUMO}

TRALBACK, Adriano Remorini. Análise ambiental histórica e atual dos córregos do município de São Carlos, SP. Dissertação (Mestrado Profissional em Ciências Ambientais) - Escola de Engenharia de São Carlos - Universidade de São Paulo, São Carlos, 2020.

A água possui uma grande importância para todos os seres vivos, notadamente, para o ser humano. A superfície do Planeta Terra é coberta por mais de três quartos por água, que em virtude da Terra encontrar-se numa zona habitável do Sistema Solar, ela ocorre no planeta nos três estados físicos: o sólido (gelo), o líquido (a água) e o gasoso (vapor d'água, na atmosfera). Porém, apenas $3 \%$ da água existente no planeta é doce, onde tal situação além de muito crítica é preocupante em virtude do continuo esgotamento e desperdício da água no mundo, bem como do aumento da poluição e degradação ambientais, as quais estão fazendo com que essas fontes de água se esgotem rapidamente ou se tornem inadequadas para o consumo. Por ser fundamental à existência de vida no planeta, a preocupação com a conservação dos seus mananciais tornou-se maior nos últimos anos e a procura de mecanismos eficazes capazes de reduzir os impactos ambientais nesses sistemas tem sido considerado com uma das prioridades de pesquisa desse século. Não apenas os países desenvolvidos vêm sendo prejudicados por esses impactos ambientais, mas, também, as nações em desenvolvimento sofrem muito com o impacto da poluição. Isto decorre do crescimento econômico desordenado associado à exploração de recursos naturais não renováveis. Baseado nessas informações, a presente pesquisa apresentou como objetivo analisar a qualidade atual dos mananciais de água de São Carlos e realizar uma análise comparativa da qualidade dos últimos 30 anos. Os dados também foram compilados para a obtenção de uma cartilha ambiental, para ser utilizada em escolas do município de São Carlos. Com os dados obtidos pretendemos conscientizar a população local sobre a importância vital que representa a água e as maneiras corretas para a manutenção da qualidade da água dos mananciais municipais para a garantia e o efetivo bem estar das gerações futuras.

Palavras-chave: Água, São Carlos, Qualidade, Mananciais. 


\section{ABSTRACT}

TRALBACK, Adriano Remorini. Historical and current environmental analysis of streams in the municipality of São Carlos, SP. Dissertação (Mestrado Profissional em Ciências Ambientais) - Escola de Engenharia de São Carlos - Universidade de São Paulo, São Carlos, 2020.

Water has great importance for all living beings, notably the human being. The surface of Planet Earth is covered by more than three quarters of water, which by virtue of the Earth is in a habitable zone of the Solar System, water occurs on the planet in the three physical states: the solid (ice), the liquid (the water) and gaseous (water vapor, in the atmosphere). However, only three percent of the existing water on the planet is sweet, where this situation, in addition to being very critical, is worrying due to the continuous depletion and waste of water in the world, as well as the increase in environmental pollution and degradation, which are causing these sources of water, which are indispensable for the survival of various species, to run out quickly or become unsuitable for consumption. Since it is fundamental to the existence of life on the planet, the concern with the conservation of its sources has become greater in recent years, and the search for effective mechanisms capable of reducing the environmental impacts in these systems has been considered as one of the research priorities for this century. Not only are developed countries affected by these environmental impacts, but developing nations are also impacted by pollution. This is due to the disorderly economic growth associated with the exploitation of non-renewable natural resources. Based on this information, the present research aimed to analyze the current water quality of water sources in the municipality of São Carlos and to carry out a comparative analysis of the quality of the last 30 years. The data were also compiled to obtain an environmental booklet, to be used in schools in the municipality of São Carlos. With the data obtained, we intend to make the local population aware of the vital importance that water represents and the correct ways to maintain the quality of water in municipal springs for the guarantee and effective well-being of future generations.

Keywords: Water, São Carlos, Quality, Springs 


\title{
LISTA DE SIGLAS
}

\author{
ANA - Agência Nacional de Águas. \\ CETESB - Companhia Estadual de Tecnologia de Saneamento Básico (Companhia \\ Ambiental do Estado de São Paulo). \\ ${ }^{\circ} \mathrm{C}$ - Grau Celsius - escala centígrada, escala termométrica do sistema métrico \\ IBGE - Instituto Brasileiro de Geografia e Estatística. \\ km - Quilômetro, unidade de medida de comprimento, que equivale a mil metros \\ p. - Página. \\ pH - Potencial Hidrogeniônico. \\ S - South (Sul). \\ USP - Universidade de São Paulo. \\ W - West (Oeste). \\ $\mu \mathrm{S} / \mathrm{cm}$ - micro siemens por centímetro, unidade de medida, relativa a condutividade \\ elétrica.
}




\section{LISTA DE FIGURAS}

\begin{tabular}{|c|c|c|}
\hline gura 1: & ural da áqua. & 21 \\
\hline Figura 2: & $\begin{array}{l}\text { As ligações dos átomos de hidrogênio que se ligam fortemente aos } \\
\text { átomos de oxigênio, formando as pontes de hidrogênio responsá- } \\
\text { veis por inúmeras propriedades da áqua. }\end{array}$ & 22 \\
\hline Figura 3: & A estrutura molecular da água. & 22 \\
\hline Figura 4: & ciclo hidrológico. & 23 \\
\hline Figura 5: & A formação de um rio desde a nascente até a sua foz. & 24 \\
\hline Figura 6: & $\begin{array}{l}\text { Diagrama esquemático da utilização da água para os mais varia- } \\
\text { dos fins. }\end{array}$ & 25 \\
\hline Figura 7: & São Carlos em relação ao Estado de São Paulo e cidades vizinhas. & 27 \\
\hline Figura 8: & Algumas das sub-bacias urbanas da cidade de São Carlos. & 28 \\
\hline Figura 9: & o Córrego do Greg & 29 \\
\hline $\begin{array}{l}\text { Figura } \\
10:\end{array}$ & realizada, no pon & 56 \\
\hline $\begin{array}{l}\text { Figura } \\
\text { 11: }\end{array}$ & $\begin{array}{l}\text { Fotografia demonstrando coleta de água, sendo realizada no } \\
\text { Ponto } 3 \text {, do córrego do Tijuco Preto, bem como o fundo do córrego } \\
\text { concretado. }\end{array}$ & 57 \\
\hline $\begin{array}{l}\text { Figura } \\
\text { 12: }\end{array}$ & $\begin{array}{l}\text { strando a visão da vegeta } \\
\text { rres no córrego Santa Mar }\end{array}$ & 59 \\
\hline Figura 13 & $\begin{array}{l}\text { ando a coleta de ág } \\
\text { dentro do campus I }\end{array}$ & 62 \\
\hline Figura 14 & $\begin{array}{l}\text { Fotografia da coleta de água no Pont } \\
\text { dentro do campus II da USP de São }\end{array}$ & 63 \\
\hline Figura 15 & $\begin{array}{l}\text { Fotografia que demonstra a coleta de água realizada no ponto } 10 \text {, } \\
\text { no córrego do Mineirinho, ponto este, que se encontrava dentro de } \\
\text { uma mata. }\end{array}$ & 64 \\
\hline Figura 16 & $\begin{array}{l}\text { Fotografia que mostram o acumulo de entulhos de telhas de ami- } \\
\text { anto e outros materiais que foram jogados, sem autorização, nos } \\
\text { fundos da USP, Campus } 2 \text {, pela população. }\end{array}$ & 65 \\
\hline Figura 17 & $\begin{array}{l}\text { Fotografia que mostram o acumulo de entulhos de telhas de ami- } \\
\text { anto e outros materiais que foram jogados, sem autorização, nos } \\
\text { fundos da USP, Campus } 2 \text {, pela população. }\end{array}$ & 65 \\
\hline Figura 18 & $\begin{array}{l}\text { Fotografia que demonstra o acúmulo de lixo orgânico, misturado } \\
\text { com plásticos e metais que foram jogados indevidamente pela po- } \\
\text { pulação na área da USP, campus } 2 \text {, em São Carlos. }\end{array}$ & 66 \\
\hline Figura 19 & $\begin{array}{l}\text { Gráfico com os valores referentes a média e o desvio padrão, tanto } \\
\text { da meta análise realizada (trabalhos realizados por pesquisadores } \\
\text { anteriores, CAMPAGNA (2005) e BAIO (2009)), quanto em relação } \\
\text { a atual análise realizada, feito pelo corrente pesquisador TRAL- } \\
\text { BACK (2020), em relação aos valores de pH da água do córrego } \\
\text { do Tijuco Preto. }\end{array}$ & 68 \\
\hline
\end{tabular}




\begin{tabular}{|c|c|c|}
\hline Figura 20 & $\begin{array}{l}\text { Gráfico com os valores referentes a média e o desvio padrão, tanto } \\
\text { da meta análise realizada (trabalhos realizados por pesquisadores } \\
\text { anteriores, CAMPAGNA (2005), BAIO (2009), ZAFFANI (2012), } \\
\text { quanto em relação a atual análise realizada, feito pelo corrente } \\
\text { pesquisador TRALBACK (2020), em relação aos valores de Tem- } \\
\text { peratura da água do córrego do Tijuco Preto. }\end{array}$ & 69 \\
\hline Figura 21 & $\begin{array}{l}\text { Gráfico com os valores referentes a média e o desvio padrão, tanto } \\
\text { da meta análise realizada (trabalhos realizados por pesquisadores } \\
\text { anteriores, CAMPAGNA (2005) e BAIO (2009)), quanto em relação } \\
\text { a atual análise realizada, feito pelo corrente pesquisador TRAL- } \\
\text { BACK (2020), em relação aos valores de condutividade elétrica da } \\
\text { água do córrego do Tijuco Preto. }\end{array}$ & 71 \\
\hline Figura 22 & $\begin{array}{l}\text { Gráfico com os valores referentes a média e o desvio padrão, tanto } \\
\text { da meta análise realizada (trabalhos realizados por pesquisadores } \\
\text { anteriores, CAMPAGNA (2005) e BAIO (2009)), quanto em relação } \\
\text { a atual análise realizada, feito pelo corrente pesquisador TRAL- } \\
\text { BACK (2020), em relação aos valores de pH (potencial Hidroge- } \\
\text { niônico), da água do córrego Santa Maria Madalena. }\end{array}$ & 72 \\
\hline Figura 23 & $\begin{array}{l}\text { Gráfico com os valores referentes a média e o desvio padrão, tanto } \\
\text { da meta análise realizada (trabalhos realizados por pesquisadores } \\
\text { anteriores, CAMPAGNA (2005), BAIO (2009) e ZAFFANI (2012)), } \\
\text { quanto em relação a atual análise realizada, feito pelo corrente } \\
\text { pesquisador TRALBACK (2020), em relação aos valores de tem- } \\
\text { peratura da água do córrego Santa Maria Madalena. }\end{array}$ & 74 \\
\hline Figu & $\begin{array}{l}\text { Gráfico com os valores referentes a média e o desvio padrão, tanto } \\
\text { da meta análise realizada (trabalhos realizados por pesquisadores } \\
\text { anteriores, CAMPAGNA (2005) e BAIO (2009)), quanto em relação } \\
\text { a atual análise realizada, feito pelo corrente pesquisador TRAL- } \\
\text { BACK (2020), em relação aos valores de condutividade elétrica da } \\
\text { água do córrego Santa Maria Madalena. }\end{array}$ & 75 \\
\hline Figu & $\begin{array}{l}\text { Gráfico com os valores referentes a média e o desvio padrão, tanto } \\
\text { da meta análise realizada (trabalhos realizados por pesquisadores } \\
\text { anteriores, CAMPAGNA (2005)), quanto em relação a atual aná- } \\
\text { lise realizada, feito pelo corrente pesquisador TRALBACK (2020), } \\
\text { em relação aos valores de pH (potencial Hidrogeniônico) da água } \\
\text { do córrego do Mineirinho. }\end{array}$ & 76 \\
\hline Figur & $\begin{array}{l}\text { Gráfico com os valores referentes a média e o desvio padrão, tanto } \\
\text { da meta análise realizada (trabalhos realizados por pesquisadores } \\
\text { anteriores, CAMPAGNA (2005) e ZAFFANI (2012)), quanto em re- } \\
\text { lação a atual análise realizada, feito pelo corrente pesquisador } \\
\text { TRALBACK (2020), em relação aos valores de temperatura da } \\
\text { água do córrego do Mineirinho. }\end{array}$ & 78 \\
\hline Figura 27 & $\begin{array}{l}\text { Gráfico com os valores referentes a média e o desvio padrão, tanto } \\
\text { da meta análise realizada (trabalhos realizados por pesquisadores } \\
\text { anteriores, CAMPAGNA (2005)), quanto em relação a atual aná- } \\
\text { lise realizada, feito pelo corrente pesquisador TRALBACK (2020), } \\
\text { em relação aos valores de condutividade elétrica da água do cór- } \\
\text { rego do Mineirinho. }\end{array}$ & 79 \\
\hline
\end{tabular}




\section{LISTA DE TABELAS}

\begin{tabular}{|l|l|l|}
\hline Tabela 1 & Porcentagem de água na biosfera & 24 \\
\hline Tabela 2 & Tabela de variáveis, símbolos, unidades e metodologia & 35 \\
\hline Tabela 3 & $\begin{array}{l}\text { Córrego do Tijuco Preto - Dados da Meta Análise e Análise das } \\
\text { coletas de água realizadas referentes ao pH da água: }\end{array}$ & 92 \\
\hline Tabela 4 & $\begin{array}{l}\text { Córrego do Tijuco Preto - Dados da Meta Análise e Análise das } \\
\text { coletas de água realizadas referentes à temperatura da água: }\end{array}$ & 93 \\
\hline Tabela 5 & $\begin{array}{l}\text { Córrego do Tijuco Preto - Dados da Meta Análise e Análise das } \\
\text { coletas de água realizadas referentes à condutividade elétrica } \\
\text { da água: }\end{array}$ & 94 \\
\hline Tabela 6 & $\begin{array}{l}\text { Córrego Santa Maria Madalena - Dados da Meta Análise e Aná- } \\
\text { lise das coletas de água realizadas referentes ao pH da água: }\end{array}$ & 95 \\
\hline Tabela 7 & $\begin{array}{l}\text { Córrego Santa Maria Madalena - Dados da Meta Análise e Aná- } \\
\text { lise das coletas de água realizadas referentes à temperatura da } \\
\text { água: }\end{array}$ & 96 \\
\hline Tabela 8 & $\begin{array}{l}\text { Córrego Santa Maria Madalena - Dados da Meta Análise e Aná- } \\
\text { lise das coletas de água realizadas referentes à condutividade } \\
\text { elétrica da água: }\end{array}$ & 97 \\
\hline Tabela 9 & $\begin{array}{l}\text { Córrego do Mineirinho - Dados da Meta Análise e Análise das } \\
\text { coletas de água realizadas referentes ao pH da água: }\end{array}$ & 98 \\
\hline Tabela 10 & $\begin{array}{l}\text { Córrego do Mineirinho - Dados da Meta Análise e Análise das } \\
\text { coletas de água realizadas referentes à Temperatura da água: }\end{array}$ & 99 \\
\hline Tabela 11 & $\begin{array}{l}\text { Córrego do Mineirinho - Dados da Meta Análise e Análise das } \\
\text { coletas de água realizadas referentes à condutividade elétrica } \\
\text { da água: }\end{array}$ & 100 \\
\hline Tabela 12: & Tabela 10 - Dados coletados por Campagna (2005, p.237): & 101 \\
\hline Tabela 13: & Tabela 11 - Dados coletados por BAlO (2009, p. 105): & 102 \\
\hline Tabela 14: & Tabela 12 - Dados coletados por BAlO (2009, p. 106): & 103 \\
\hline Tabela 15: & Tabela 13 - Dados coletados por ZAFFANI (2012, p. 79): \\
\hline
\end{tabular}




\section{SUMÁRIO}

\begin{tabular}{|l|l|}
\hline 1 - Introdução Geral & 19 \\
\hline 2 - Objetivos & 20 \\
\hline 2.1- Objetivo geral & 20 \\
\hline 2.2 - Objetivos específicos & 20 \\
\hline 3 - Revisão de Literatura & 20 \\
\hline 3.1 - A água e sua composição física e química & 20 \\
\hline 3.2 - O ciclo hidrológico & 23 \\
\hline 3.3 - A formação dos rios e córregos & 23 \\
\hline 3.4 - A distribuição de água na biosfera & 24 \\
\hline 3.5 - A utilização da água e os impactos ambientais & 25 \\
\hline 4 - Materiais e Métodos & 26 \\
\hline 4.1 - O município de São Carlos & 26 \\
\hline 4.2 - As nascentes de água do município de São Carlos & 27 \\
\hline 4.2 .1 - O córrego do Gregório & 28 \\
\hline 4.2 .2 - O córrego do Mineirinho & 29 \\
\hline 4.2 .3 - O córrego Santa Maria Madalena (Santa Maria do Leme) & 30 \\
\hline 4.2 .4 - O córrego do Tijuco Preto & 30 \\
\hline 4.2 .5 - O Rio Monjolinho & 30 \\
\hline 4.3 - Variáveis Físicas (temperatura e condutividade elétrica) e químicas (pH) & 31 \\
\hline utilizadas na pesquisa, para aferir a qualidade da água & 31 \\
\hline 4.3 .1 - A temperatura da água & 32 \\
\hline 4.3 .2 - Potencial Hidrogeniônico - pH & 33 \\
\hline 4.3 .3 - A condutividade elétrica da água & 31 \\
\hline
\end{tabular}




\begin{tabular}{|c|c|}
\hline $4.4-$ A metodologia utilizada na pesquisa & 35 \\
\hline $\begin{array}{l}5 \text { - Resultados - meta análise histórica de dados obtidos por outros pes- } \\
\text { quisadores }\end{array}$ & 35 \\
\hline 5.1 - Córrego do Tijuco Preto & 36 \\
\hline $\begin{array}{l}\text { 5.1.1 - Quanto ao pH (potencial Hidrogeniônico) da água do córrego do Tijuco } \\
\text { Preto }\end{array}$ & 36 \\
\hline 5.1.1.1 - Ano de 2003 & 36 \\
\hline 5.1.1.2 - Ano de 2004 & 36 \\
\hline 5.1.1.3 - Ano de 2008 & 37 \\
\hline 5.1.2 - Quanto a temperatura da água no córrego do Tijuco Preto & 38 \\
\hline 5.1.2.1 - Ano de 2003 & 38 \\
\hline 5.1.2.2 - Ano de 2004 & 39 \\
\hline 5.1.2.3 - Ano de 2008 & 39 \\
\hline 5.1.2.4 - Ano de 2012 & 41 \\
\hline 5.1.3 - Quanto a condutividade elétrica da água no córrego do Tijuco Preto & 42 \\
\hline 5.1.3.1 - Ano de 2003 & 42 \\
\hline 5.1.3.2 - Ano de 2004 & 42 \\
\hline 5.1.3.3 - Ano de 2008 & 43 \\
\hline 5.2 - Córrego Santa Maria Madalena & 44 \\
\hline $\begin{array}{l}\text { 5.2.1 - Quanto ao pH (potencial Hidrogeniônico), da água no córrego Santa } \\
\text { Maria Madalena }\end{array}$ & 44 \\
\hline 5.2.1.1 - Ano de 2003 & 44 \\
\hline 5.2.1.2 - Ano de 2004 & 45 \\
\hline 5.2.1.3 - Ano de 2008 & 45 \\
\hline 5.2.2 - Quanto a temperatura da água no córrego Santa Maria Madalena & 46 \\
\hline 5.2.2.1 - Ano de 2003 & 46 \\
\hline 5.2.2.2 - Ano de 2004 & 47 \\
\hline 5.2.2.3 - Ano de 2008 & 47 \\
\hline 5.2.2.4 - Ano de 2012 & 48 \\
\hline $\begin{array}{l}\text { 5.2.3 - Quanto a condutividade elétrica da água do córrego Santa Maria Ma- } \\
\text { dalena }\end{array}$ & 49 \\
\hline 5.2.3.1 - Ano de 2003 & 49 \\
\hline
\end{tabular}




\begin{tabular}{|c|c|}
\hline 5.2.3.2 - Ano de 2004 & 50 \\
\hline 5.2.3.3 - Ano de 2008 & 50 \\
\hline 5.3 - O córrego do Mineirinho & 51 \\
\hline $\begin{array}{l}\text { 5.3.1 - Quanto ao pH (potencial Hidrogeniônico) da água do córrego do Mi- } \\
\text { neirinho }\end{array}$ & 51 \\
\hline 5.3.1.1 - Ano de 2003 & 51 \\
\hline 5.3.1.2 - Ano de 2004 & 52 \\
\hline 5.3.2 - Quanto a temperatura da água do córrego do Mineirinho & 52 \\
\hline 5.3.2.1 - Ano de 2003 & 52 \\
\hline 5.3.2.2 - Ano de 2004 & 53 \\
\hline 5.3.2.3 - Ano de 2012 & 53 \\
\hline 5.3.3. - Quanto a condutividade elétrica da água do córrego do Mineirinho & 54 \\
\hline 5.3.3.1 - Ano de 2003 & 54 \\
\hline 5.3.3.2 - Ano de 2004 & 55 \\
\hline 6 - Resultados da análise atual dos córregos & 55 \\
\hline 6.1 - O córrego do Tijuco Preto & 55 \\
\hline $6.1 .1-$ Ponto 1 & 55 \\
\hline 6.1 .2 - Ponto 2 & 56 \\
\hline 6.1.3 - Ponto 3 & 57 \\
\hline 6.2 - Córrego Santa Maria Madalena & 58 \\
\hline 6.2.1 - Ponto 4 & 59 \\
\hline 6.2 .2 - Ponto 5 & 60 \\
\hline 6.2.3 - Ponto 6 & 60 \\
\hline 6.3 - O córrego do Mineirinho & 61 \\
\hline 6.3.1- Ponto 7 & 61 \\
\hline 6.3.2 - Ponto 8 & 62 \\
\hline 6.3.3 - Ponto 9 & 63 \\
\hline 6.3.4. - Ponto 10 & 64 \\
\hline $\begin{array}{l}7 \text { - Resultados referentes a análise histórica (coletas anteriores) e análise } \\
\text { atual (presente estudo) }\end{array}$ & 67 \\
\hline 7.1 - O córrego do Tijuco Preto quanto ao $\mathrm{pH}$ da água & 67 \\
\hline 7.2 - O córrego do Tijuco Preto quanto a temperatura da água & 68 \\
\hline
\end{tabular}




\begin{tabular}{|l|r|}
\hline 7.3 - O córrego do Tijuco Preto quanto a condutividade elétrica da água & 70 \\
\hline 7.4 - O córrego Santa Maria Madalena quanto ao pH da água & 72 \\
\hline 7.5 - O córrego Santa Maria Madalena quanto a temperatura da água & 73 \\
\hline $\begin{array}{l}\text { a.6 - O córrego Santa Maria Madalena quanto a condutividade elétrica da } \\
\text { água }\end{array}$ & 74 \\
\hline 7.7 - O córrego do Mineirinho quanto ao pH da água & 75 \\
\hline 7.8 - O córrego do Mineirinho quanto a temperatura da água & 77 \\
\hline 7.9 - O córrego do Mineirinho quanto a condutividade elétrica da água & 78 \\
\hline 8 - Conclusão & 80 \\
\hline - Referências Bibliográficas & 82 \\
\hline 10 - Apêndice & 91 \\
\hline 11 - Produto Final - Cartilha de Educação Ambiental & 105 \\
\hline
\end{tabular}




\section{1 - INTRODUÇÃO GERAL}

A água é um dos pilares básicos e mais importantes para a vida. Como afirma GARDEL et. al. (2004, p.89), os primeiros grupos humanos ao fixarem suas moradias procuravam estabelecerem-se próximos a rios, lagos e mares fazendo que os humanos deixassem de serem nômades e fixassem-se nos locais, desenvolvendo a agricultura, o comércio e a indústria. GARDEL et. al. (2004, p. 107), definem água como:"... uma das substâncias mais importantes para a vida de uma pessoa. Desde o momento em que acordamos até nos deitarmos, confrontamo-nos com diversas situações que requerem o uso da água". Ainda, GARDEL et. al. (2004, p.78), atribui a água um símbolo de saúde e bem-estar, sendo classificada como potável, a água que se encontra livre de impurezas ou micróbios, servindo então para que a mesma, seja bebida.

Para Esteves (2011) a água, principalmente a água doce, se encontra cada vez mais escassa, onde no atual século é um dos produtos mais visados por todas as sociedades, denotando a grande importância deste item como um fato de sobrevivência estratégica das nações. WALLACE (2002, p. 91), afirmou que: "A água por exemplo, ameaça substituir o petróleo como o líquido de disputa internacional".

De acordo com Eid et. al. (2004, p. 85), vários fatores contribuem para que a água seja uma substância rara, que é considerada tão essencial e, até recentemente, se encontrava presente em todos os lugares, que é água. Entre esses fatores, os principais são: o crescimento populacional, a poluição por falta de saneamento, o desmatamento, a construção de hidrelétricas e as mudanças climáticas que acabam fazendo chover onde já é úmido enquanto aumentam a seca dos desertos. Nesse interim, o uso da água urbana passou por contínuas transformações ao longo da História, que vão desde o lançamento de esgotos sem qualquer tratamento e a transmissão de inúmeras doenças num primeiro momento até o momento atual referente à recuperação de nascentes e rios a cobrança cada vez mais exigida por governos, autoridades e entidades de tratamentos eficazes para o despejo de esgotos e efluentes que são lançados nos rios das cidades diariamente. 


\section{2 - OBJETIVOS}

\section{1 - Objetivo geral}

O presente estudo apresenta como objetivo realizar uma análise histórica e atual da qualidade da água de córregos do município de São Carlos, SP.

\section{2 - Objetivos específicos}

- 'Realizar uma pesquisa de campo em algumas nascentes de água do município de São Carlos, aferindo as variáveis "pH", "Temperatura" e "Condutividade Elétrica".

-Realizar uma revisão bibliográfica num período de trinta anos, envolvendo pesquisas sobre o tema "Água", na cidade de São Carlos;

- Produzir uma Cartilha de Educação Ambiental abordando o tema "Água", para ser utilizada em sala de aula, com alunos do ensino fundamental II de escolas do município de São Carlos.

\section{3 - REVISÃO DE LITERATURA}

\section{1 - A água e sua composição física e química}

De acordo Branco (2010, p. 25) o termo água provém dos tempos antigos, onde Aristóteles (384 a.C. - 322 a.C.) e outros filósofos mencionavam esse termo quando acreditavam que o mundo era formado por 4 elementos principais: o fogo, o ar, a terra e a água. Nesse sentido, a água seria para estes filósofos um corpo simples e primário, não podendo por esse motivo, ser decomposto em substâncias consideradas mais elementares, ideia esta, que acabou prevalecendo por um período de mais de 2 mil anos, até o século XVIII. 
Ainda, segundo o autor, em 1781, o inglês Joseph Priestley (1733-1804), que era um químico e teólogo conseguiu sintetizar a água através do processo da combustão do hidrogênio, mediante um aquecimento explosivo, não conseguindo, no entanto, perceber que esta combustão era fruto da combinação desse elemento (hidrogênio) com o oxigênio. Esse cientista acabou descobrindo o oxigênio e demonstrou que as plantas produzem esse gás quando se encontram na presença de luz, fenômeno que é conhecido como fotossíntese.

Nessa época mencionada pelo Autor (2010, p. 26), ainda viveu um outro grande cientista, LAVOSIER (Antonie-Laurent Lavosier, 1743-1794), o qual acabou conseguindo demonstrar que a água era composta de dois elementos químicos, o hidrogênio e o oxigênio. Posteriormente, em 1805, GAY-LUSSAC, (Louis-Joseph Gay-Lussac, 1778-1850) e HUMBOLDT, (Alexander von Humboldt, 1769-1859) estudando as proporções existentes entre um e outro elemento, concluíram de na molécula de água, tal proporção era de 2 para 1, o que acabou determinando a fórmula $\mathrm{H}_{2} \mathrm{O}$.

O que torna a molécula de água complexa em relação a sua estrutura interna como afirma o autor, são as chamadas pontes de hidrogênio, que devido as forças de atração que atuam entre os átomos e as moléculas acabam mantendo unidos os elementos químicos (Figura 1).

Figura 1: A fórmula estrutural da água.

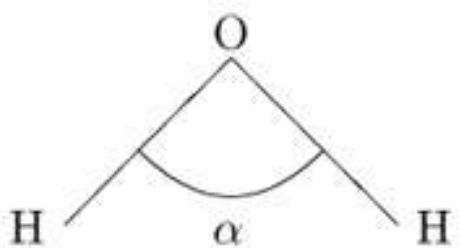

Figura 1: Representação esquemática da estrutura de uma molécula de água, indicando-se os elementos que a compõem. $\mathrm{O}$ ângulo entre os átomos de hidrogênio é de $\alpha=104,95^{\circ}$, e a distância entre o átomo de oxigênio e cada um dos átomos de hidrogênio é de $0,9504 \AA$. Não há diferenças intrínsecas entre duas moléculas de água: elas são indiscerníveis, e o mesmo se dá com seus elementos constituintes de mesma espécie.

Fonte: SCHINAIDER, Jaison; KRAUSE, Décio "Indiscernibilidade e identidade em química: aspectos filosóficos e formais" Artigo Científico no "site" SCIELO - disponível em:< https://www.scielo.br/scielo.php?script=sci_arttext\&pid=S0100-60452014000100004 >, acesso em 22 de agosto de 2020. 
Nas figuras 2 e 3, abaixo, observa-se as ligações existentes na molécula de água e as suas polaridades (positivo e negativo) existentes entre os elementos químicos Hidrogênio e Oxigênio que acabam atraindo-se (polos opostos se atraem e polos iguais se repelem), formando a ligação covalente da água.

Figura 2: As ligações dos átomos de hidrogênio que se ligam fortemente aos átomos de oxigênio, formando as pontes de hidrogênio responsáveis por inúmeras propriedades da água

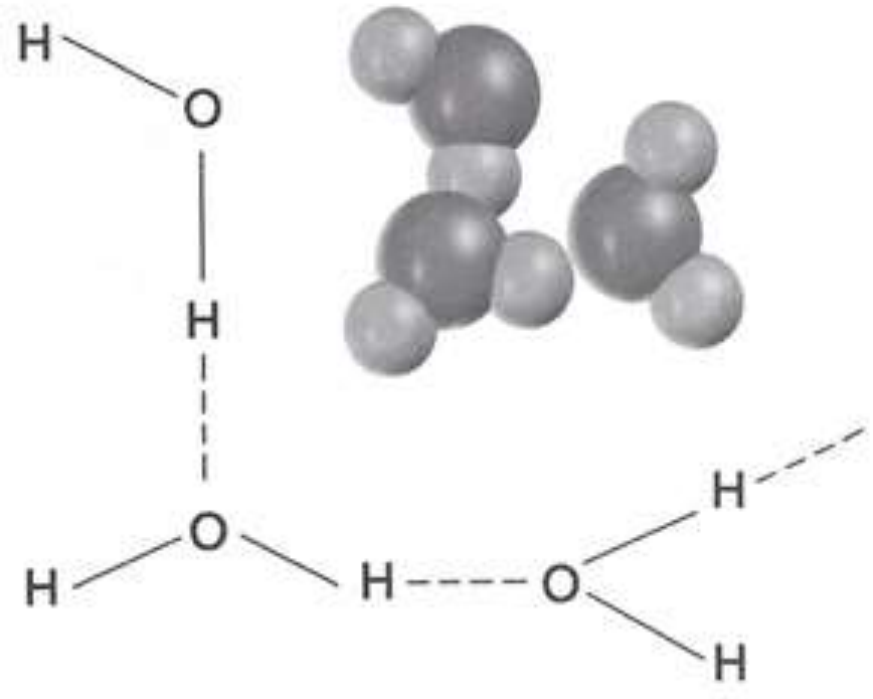

Fonte: BRANCO (2013, p. 28).

A figura abaixo (figura 3), apresenta as polaridades existente entre os elementos nas moléculas de água, onde pelo princípio da atração e repulsão, polos contrários se atraem e polos iguais se repelem, mantém a força para manter a molécula unida, na ligação química covalente que é formada, dando origem as chamadas pontes de hidrogênio.

Figura 3: A estrutura molecular da água

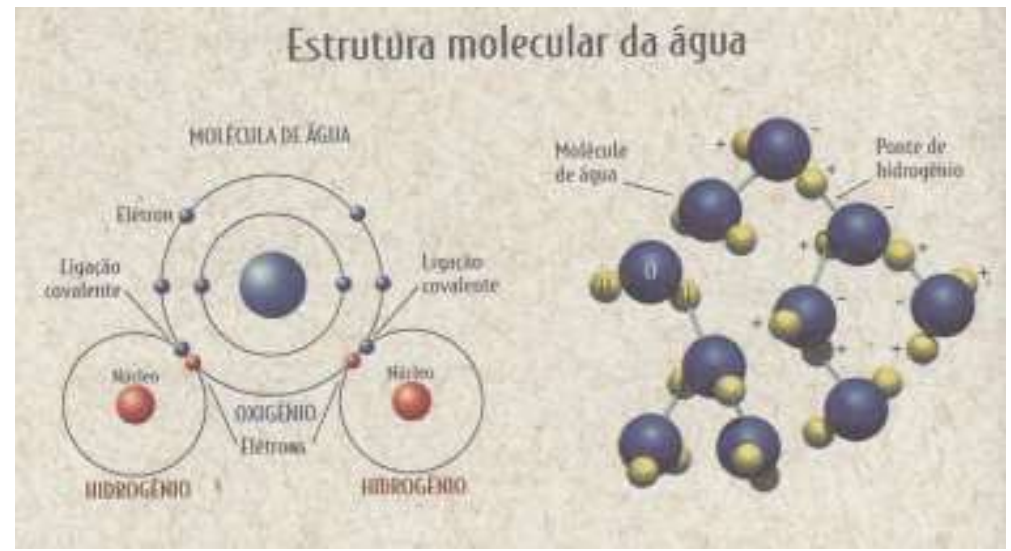

Fonte: EID et. al. (2004, p.36) 


\section{2 - 0 ciclo hidrológico}

O Ciclo Hidrológico, de acordo com Tundisi (2005, p. 6), apud PIELOU (2008), pode ser considerado um "ciclo de vida" sendo que a história natural envolvendo a água no planeta, está relacionada aos "ciclos de vida" bem como a história da vida. Para TUCCl et. al. (1993, p.297), o ciclo hidrológico "é um sistema fechado com armazenamento de água na superfície do terreno, em rios e lagos, nos oceanos, na atmosfera e no subsolo". Tal sistema, foi esquematizado da seguinte maneira conforme demonstrado na Figura 4.

Figura 4: O ciclo hidrológico

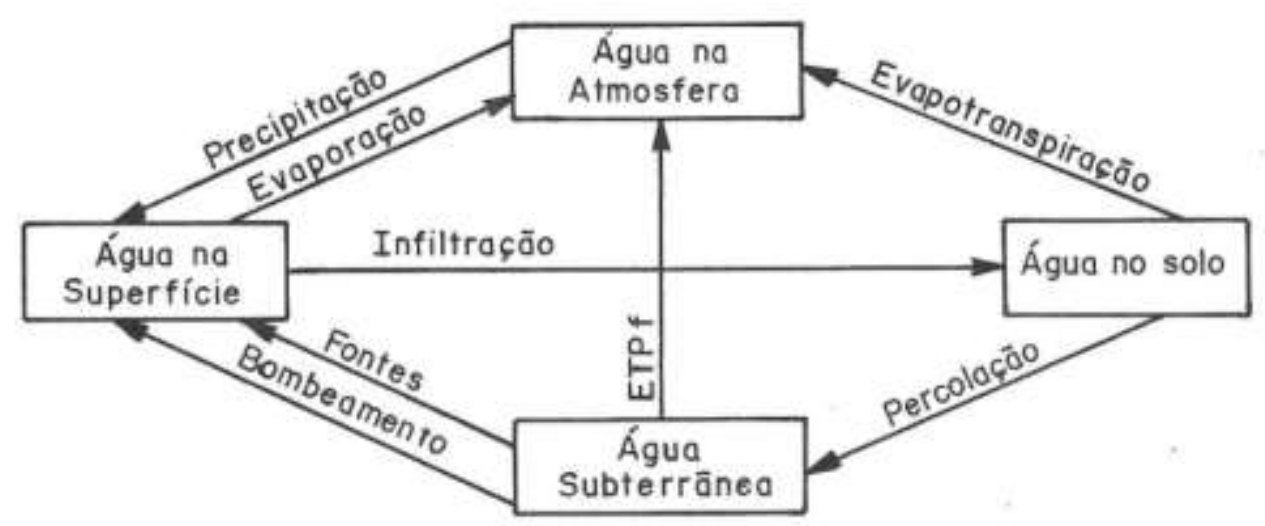

Fonte: TUCCl et. al. (1993, p.298)

\section{3 - A formação dos rios e córregos}

SAUVAIN (1998, p.4), em sua obra, faz menção, por meio da Figura 5, como são formados os rios e córregos, desde a sua nascente até a sua foz. Analisando essa figura, podemos observar que todo córrego é formado a partir de nascentes de água que, ao se juntar a outras nascentes formam pequenos corpos de água que vão aumentando seu volume, até iniciar a formação dos córregos e posteriormente ribeirões e rios. 
Figura 5: A formação de um rio desde a nascente até a sua foz

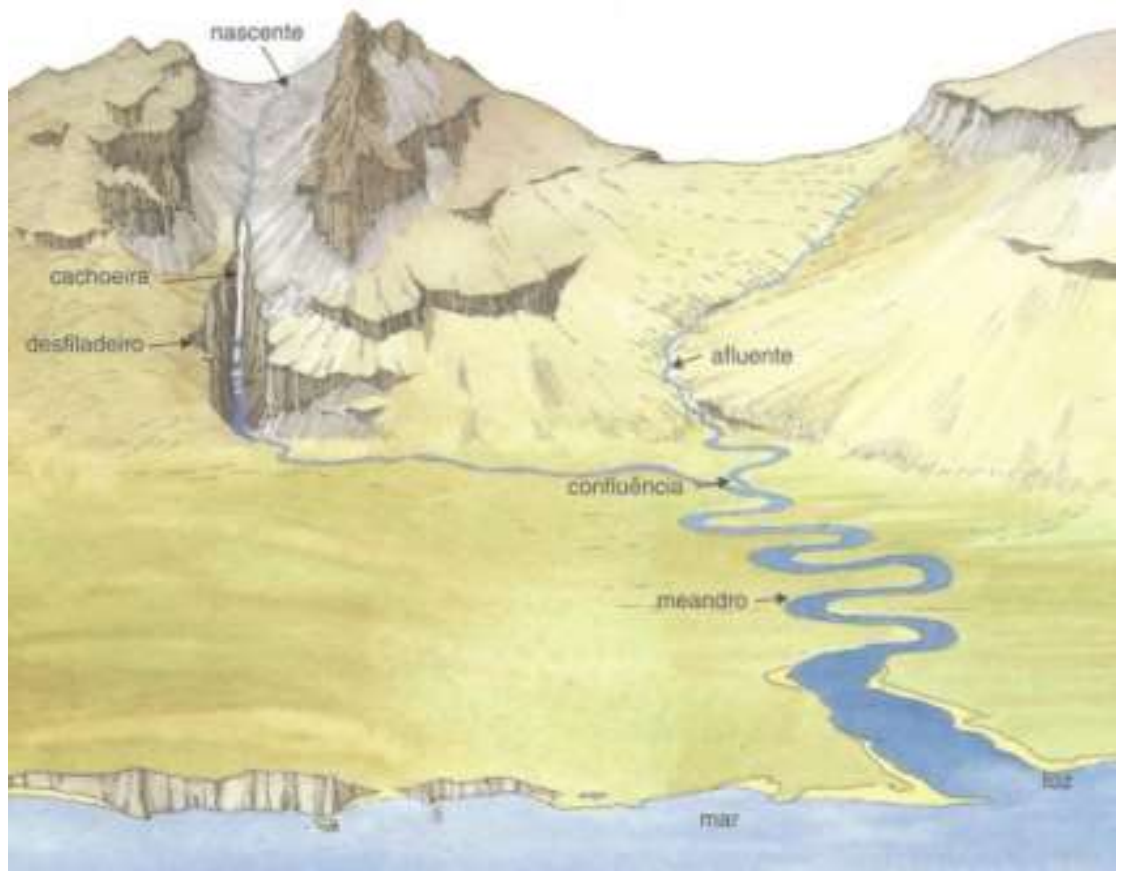

Fonte: SAUVAIN (1998, p. 4)

\section{4 - A distribuição da água na biosfera}

Devido as dimensões do Planeta Terra, bem como as diferentes formas de disposição e distribuição de água na biosfera, diversos autores, acabam divergindo entre si, no tocante as porcentagens relativas a distribuição da água na Terra, conforme pode-se verificar nas diversas tabelas apresentadas pelos autores nas Figuras à seguir elencadas:

Para JÚNIOR et. al. (2005, p. 177), a água na biosfera é dividida da seguinte maneira, conforme Tabela 1.

Tabela 1: Porcentagem de água na biosfera

\begin{tabular}{ccc}
\hline Corpo de Água & Volume $\left(\right.$ milhares de $\left.\mathrm{km}^{3}\right)$ & \% do total \\
\hline Oceanos & 1.370 .000 & 97,61 \\
Calotas e Geleiras & 29.000 & 2,08 \\
Água subterrânea & 4.000 & 0,29 \\
Lagos de água doce & 125 & 0,009 \\
Lagos salinos & 104 & 0,008 \\
Umidade do Solo & 67 & 0,005 \\
Vapor de água atmosférico & 14 & 0,0009 \\
Rios & 1,2 & 0,00009 \\
\hline
\end{tabular}

Fonte: JUNIOR et. al. (2005, p.177) adaptado pelo presente estudo 


\section{5 - A utilização da água e os impactos ambientais}

GARDEL et. al. (2004, p. 71), fazem menção as diversas formas de utilização da água pelos seres humanos para os mais variados fins, conforme o diagrama esquemático representado na Figura 6. Neste diagrama, podemos observar que a água geralmente é utilizada para dessedentação, saneamento e higiene, lazer e em atividades industriais. TUCCI et. al. (1993, p. 850-851), fazem menções as utilizações da água nos mais diversos locais e tendo as mais diversas finalidades, desde legítimas até mesmo necessárias face os progressos industriais e sociais alcançados pela humanidade. Entre essas utilizações, (TUCCl et. al. (1993, p. 850-851), citam: o abastecimento público, o consumo industrial, a matéria prima para a indústria, a utilização da água na irrigação, a utilização da água em práticas recreativas, o uso da água nas atividades que envolvam a dessedentação de animais, em atividades para a geração de energia elétrica, para o transporte (hidrovias), para a diluição de despejos e para a preservação da flora e fauna (como fontes proteicas).

Figura 6: Diagrama esquemático da utilização da água para os mais variados fins

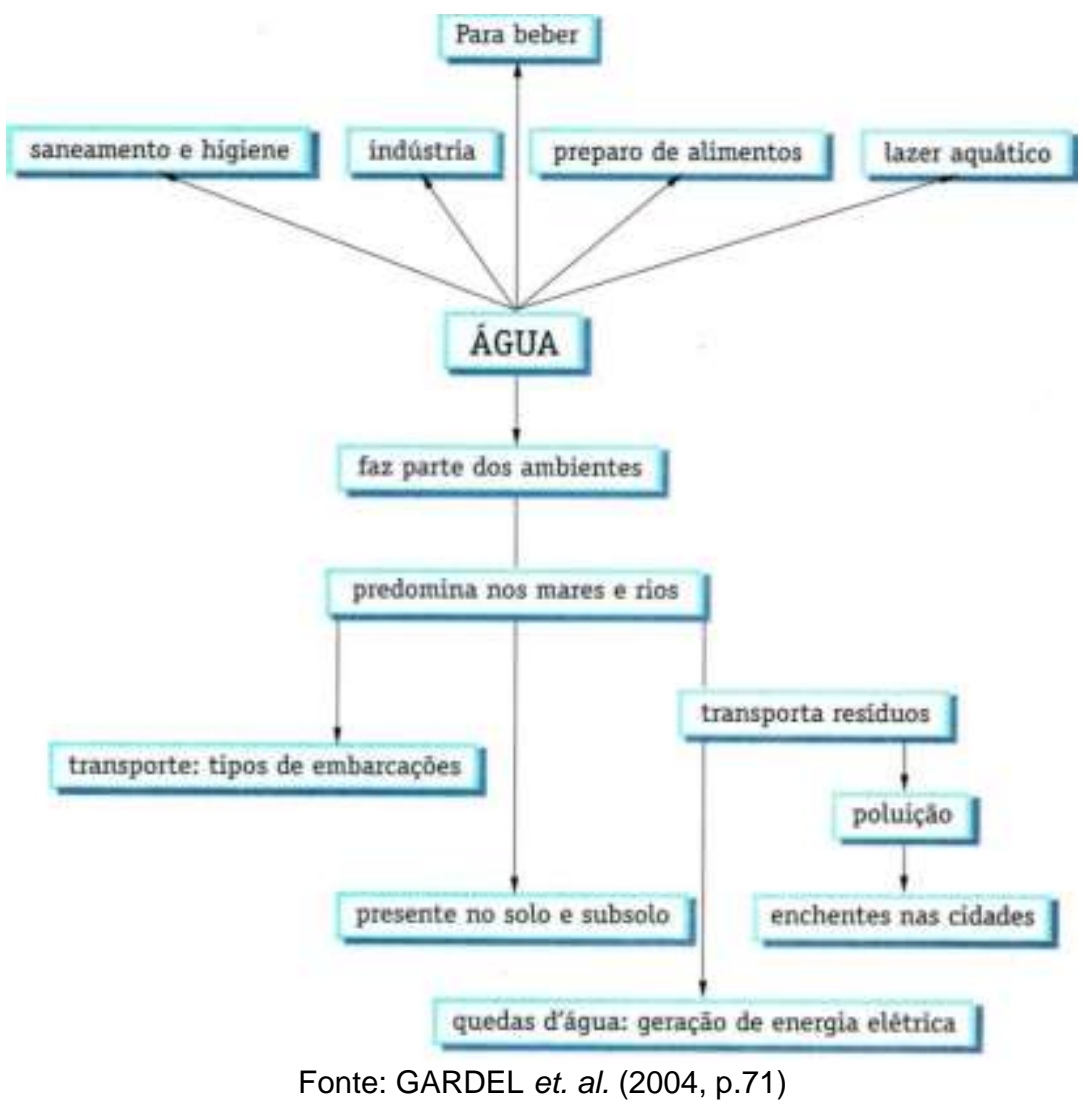


Por ser fundamental à existência de vida no planeta, a preocupação com a conservação dos seus mananciais tornou-se maior nos últimos anos, e a procura de mecanismos eficazes capazes de reduzir os impactos ambientais nesses sistemas tem sido considerado com uma das prioridades de pesquisa desse século (Negreiros, 1997). A poluição ambiental, principalmente dos mananciais tornou-se assunto de interesse público e da comunidade científica em geral. Vários estudos têm sido conduzidos com o objetivo de se averiguar os impactos resultantes da atividade agrícola (diferentes tipos de cultura e manejos de solo), das atividades de mineração e de efluentes domésticos e industriais (Corbi et al., 2000).

A expansão da indústria e da agricultura trouxe milhares de novos produtos que são aportados em toneladas para os rios e oceanos. Essas substâncias como fertilizantes (micronutrientes e macronutrientes) ricos em diferentes tipos de metais tais como, $\mathrm{Pb}, \mathrm{Ni}, \mathrm{Cr}$ e $\mathrm{Cd}$ e organoclorados (BHC, Aldrin, Dieldrin) causam alterações sensíveis nos ecossistemas aquáticos podendo acarretar em problemas de bioacumulação em diferentes níveis tróficos, como, por exemplo, se acumulando na gordura de peixes e crustáceos ou ainda em aves e outros animais terrestres, como no leite das vacas que utilizam as águas de córregos e de rios contaminados (Oliveira \& Tornisielo, 2000; Santos, 1999). Dessa forma, os ecossistemas aquáticos acabam, de certa forma, servindo como reservatórios temporários ou finais de uma grande variedade e quantidade de poluentes lançados no ar, no solo ou diretamente nos corpos d'água. Embora sejam conhecidos os progressos a respeito de metodologias de controle da poluição em recursos hídricos causada por efluentes industriais, domésticos ou advindos das atividades agrícolas ainda não são conhecidas técnicas suficientemente eficientes para o controle absoluto desses agentes poluidores (Alves, 1997).

\section{4 - MATERIAIS E MÉTODOS}

\section{1 - O município de São Carlos}

De acordo com ANELLI (2005, p.14), a cidade de São Carlos foi fundada em 1857, tendo a sua forma urbana caracterizada por um traçado hipodâmico (plano urbanístico introduzido pelos gregos), com a existência de quarteirões quadrados, de 
aproximadamente $100 \mathrm{~m}$. de lado, os quais foram dispostos em ruas orientadas de acordo com os pontos cardeais. Porém, ainda, segundo o autor, esse plano urbanístico acabou ignorando as particularidades geomorfológicas do território no qual a cidade foi construída, ou seja, ser situada numa zona montanhosa, possuindo por esse motivo um terreno com grandes declividades, tendo uma enorme quantidade de nascentes, sendo uma divisora das águas das bacias dos rios Tietê/Jacaré e Mogi/Grande. Em razão do plano urbanístico, muitas das nascentes foram ocultadas em caixas de drenagem, onde foi implantado um traçado geométrico ortogonal de forma abstrata, em clara submissão a pré-existência natural. ANELLI (2005, p.14).

A Figura 7, traz a localização da cidade de São Carlos, em relação ao Estado de São Paulo e cidades vizinhas:

Figura 7: São Carlos em relação ao Estado de São Paulo e cidades vizinhas

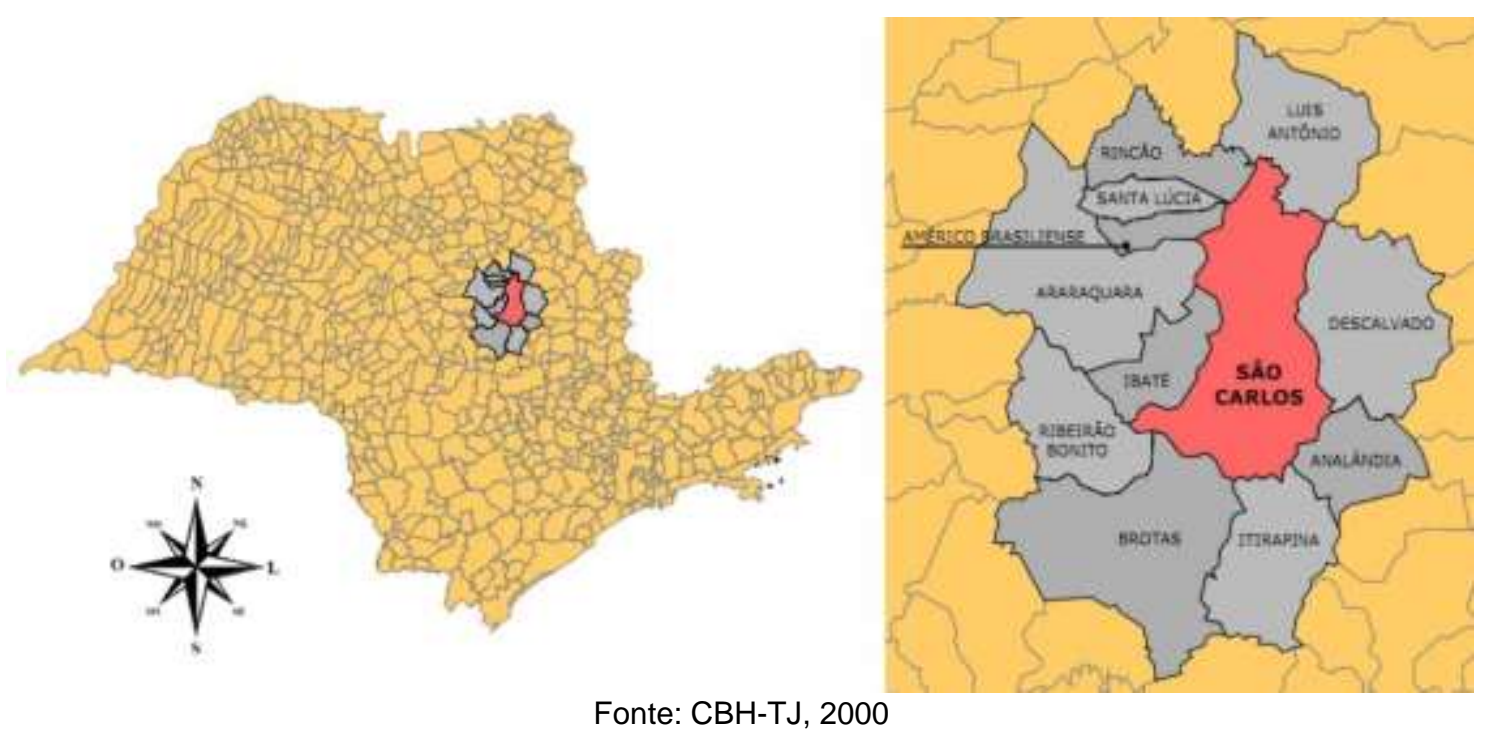

4.2 - As nascentes de água do município de São Carlos

Conforme Baio (2009), citando MONTAÑO (2002), o município de São Carlos foi subdividido em 10 sub-bacias hidrográficas: Monjolinho, Jacaré-Guaçu, Feijão, Quilombo, Araras, Cabaceiras, Chibarro, Pântano, Mogi 1 e Mogi 2 (Guabirobas). Ainda, segundo Baio, a cidade está localizada em sua totalidade na sub-bacia do Monjolinho, uma parte na região Sudeste está situada na sub-bacia do Pântano e apenas o distrito de Santa Eudóxia, situa-se na sub-bacia do Quilombo (Figura 8). 
Figura 8: Algumas das sub-bacias urbanas da cidade de São Carlos

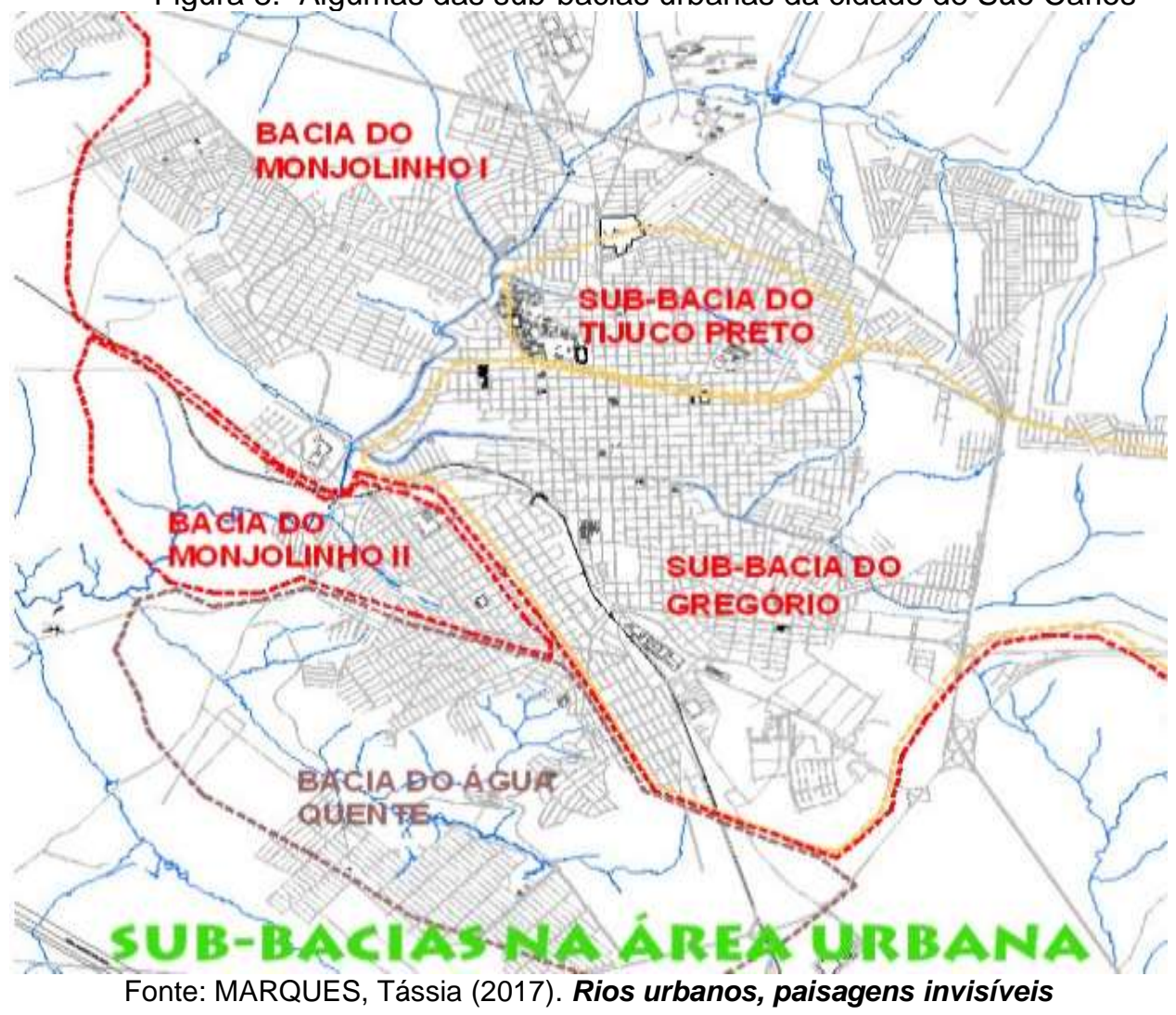

\subsection{1 - O Córrego do Gregório}

De acordo com Baio (2009, p. 17), o córrego do Gregório nasce a leste da cidade de São Carlos, na fazenda recanto Feliz, que tem coordenadas $47^{\circ} 46^{\prime} 03^{\prime \prime}$ W e $22^{\circ} 01^{\prime} 49^{\prime \prime} \mathrm{S}$, onde o córrego corre no sentido oeste em uma extensão aproximada de sete quilômetros, até desembocar no Rio Monjolinho.

A Figura 9, a seguir, traz a localização da bacia Hidrográfica do Córrego do Gregório: 
Figura 9: Bacia Hidrográfica do Córrego do Gregório $200000 \quad 201000 \quad 202000 \quad 203000 \quad 204000 \quad 205000 \quad 206000 \quad 207000$

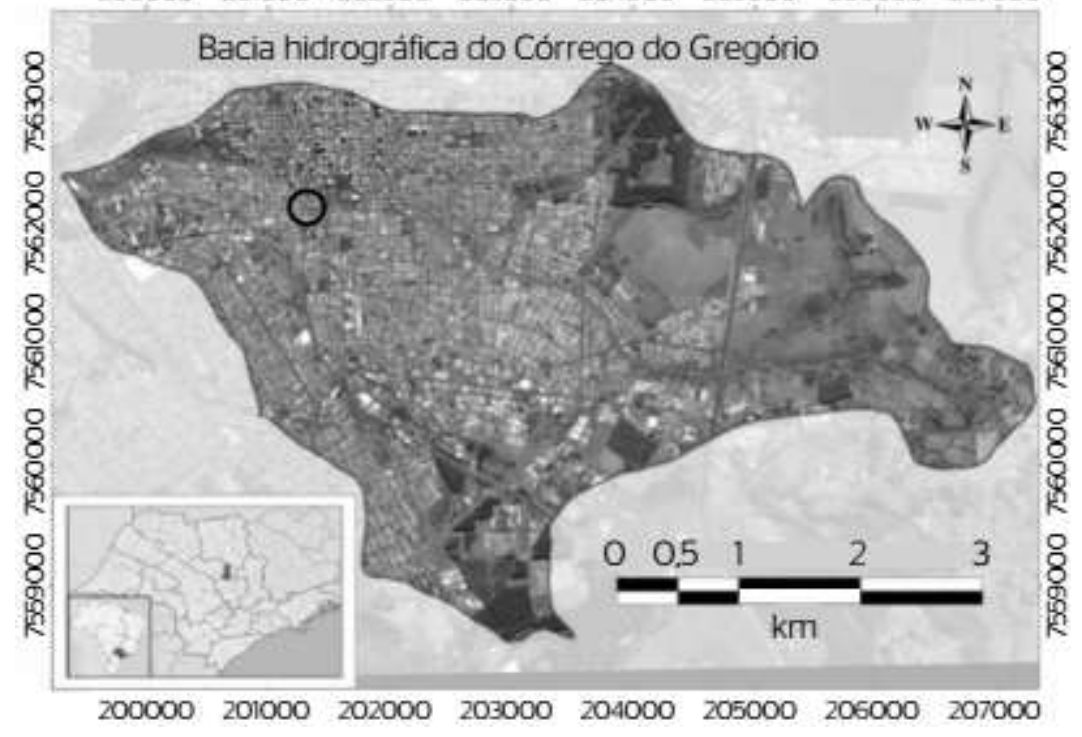

Fonte: Martins (2012)

\subsection{2 - O Córrego do Mineirinho}

BENINI et. al (2003, p.2), caracteriza a micro bacia do Córrego do Mineirinho, como localizada na região cento oeste do município de São Carlos, estando inserida na bacia do rio Monjolinho, ocupando parcialmente o perímetro urbano da cidade, onde, nos últimos anos vem passando por um processo acelerado de urbanização, que está relacionada com a chamada especulação imobiliária, o que está segundo os autores, reduzido à área rural da micro bacia.

Segundo os autores, BENINI et. al (2003, p.2), o percurso total do córrego é de aproximadamente $4 \mathrm{~km}$, e sua principal nascente situa-se em um bairro residencial denominado Santa Angelina, existindo também, mas duas nascentes que formam outros afluentes. Na área da microbacia há urbanização em dois afluentes da cabeceira (nascentes), e no seu entorno, encontram-se pastagens, monocultura de cana-deaçúcar, regiões sem cobertura vegetal e uma ferrovia, a qual circunda seu divisor de águas. Ainda, de acordo com os autores BENINI et. al (2003, p.2), nos cursos do córrego, existem trechos de mata ciliar, áreas de florestas paludosa e áreas alagadas com vegetação de pequeno porte (gramíneas). 


\subsection{3 - O Córrego Santa Maria Madalena (Santa Maria do Leme)}

O Córrego Santa Maria Madalena ou Córrego Santa Maria do Leme como também é chamado, de acordo com BAIO (2009, p. 17),tem a sua nascente próxima ao perímetro urbano da cidade de São Carlos, na fazenda Salsalito, que está localizada nas coordenadas - 47065'11" de Longitude (W) e - 21058'05" de Latitude Sul, tendo um comprimento de aproximadamente $5 \mathrm{~km}$, onde sua foz desagua no Rio Monjolinho.

\subsection{4 - O Córrego do Tijuco Preto}

De acordo com BAIO (2009, p.17), a nascente do córrego do Tijuco Preto encontra-se dentro da cidade de São Carlos a aproximadamente 30 metros para leste da Rua Monteiro Lobato na Vila Nery, localizada nas coordenadas 4752'30" de longitude (Oeste) e 2200'35,1" de latitude (Sul).

\subsection{5 - O Rio Monjolinho}

TUNDISI et. al. (2008), afirma que o Rio Monjolinho, possui 43,3 km de comprimento e é o principal rio da sub-bacia de mesmo nome, pertencente à bacia TietêJacaré.

BAIO (2009, p. 16), citando ESPINDOLA et.al. (2000), revela que o rio Monjolinho nasce na região leste de São Carlos percorre o sentido Leste-Oeste, tendo uma extensão de 43,25 km. Na área urbana, o rio é canalizado, recebendo diversos afluentes como o Córrego Santa Maria Madalena ou Santa Maria do Leme, o Córrego do Tijuco Preto e o Córrego do Gregório. 


\title{
4.3 - Variáveis Físicas (temperatura e condutividade elétrica) e químicas (pH) utilizadas na Pesquisa, para aferir a qualidade da água
}

Quanto as variáveis físicas, químicas encontradas na água, Tonissi (2005), apud Whitton (1975) afirmou que:

\begin{abstract}
"a composição química dos sistemas lóticos é o resultado de diversos processos, como a decomposição das rochas, clima, características geológicas e vegetação. Contudo, uma considerável influência nas composições das águas dos rios e córregos é provocada pelos usos múltiplos que os seres humanos fazem destes e das atividades que ocorrem nas bacias de drenagem".
\end{abstract}

\subsection{1 - A Temperatura da água}

De acordo com ANA, Agência Nacional de Águas, (2019, unidade 3, p.9-10.), a temperatura da água é resultado da radiação solar que incide sobre a água, exercendo grande influência nas atividades biológicas e no crescimento dos organismos. A Temperatura, de acordo com o autor institucional supracitado, determina também os tipos de organismos que habitam o local, vez que estes organismos tem uma faixa de temperatura preferida para se desenvolverem e se este limite for ultrapassado, tanto para mais quanto para menos, os organismos são impactados e espécies mais sensíveis podem até mesmo serem extintas do local.

Além disso, ainda de acordo com ANA, Agência Nacional de Águas, (2019, unidade 3, p. 10.), a temperatura influencia a química da água, haja vista que corpos de água fria tem maior capacidade de reter o oxigênio dissolvido do que a água quente. A temperatura também é a principal responsável por uma das características físicas da água: a densidade. Nesse sentido, as diferenças de temperatura geram camadas d'água com diferentes densidades, formando uma barreira física que impede que se misturem, e quando a energia do vento não é suficiente para misturá-las, o calor não se distribui uniformemente na coluna d'água, criando assim a estratificação térmica. 


\subsection{2 - Potencial Hidrogeniônico - pH}

Alvarez (2010, p. 15), apud Von Sperling (1996), define esse indicador conhecido com $\mathrm{pH}$, por representar a concentração de íons hidrogênio $\mathrm{H}^{+}$(em escala antilogarítmica), dando uma indicação sobre a condição de acidez, neutralidade ou alcalinidade da água, onde, o pH varia entre 0 e 14 (muito ácido a muito alcalino), sendo o valor 7, considerado neutro. Ainda, de acordo com Alvarez (2010, p. 15), apud Gastaldini \& Mendonça (2001), o pH influencia muitos processos biológicos e químicos nos corpos da água e os processos associados com o abastecimento e tratamento de águas residuárias. Para Di Bernardo \& Dantas (2005), o pH trata-se de uma variável importante nas etapas de coagulação, filtração, desinfecção e controle da corrosão, onde, nos sistemas de abastecimento, águas com valores baixos de $\mathrm{pH}$ tendem a ser corrosivas ou agressivas a certos metais e paredes de concreto, enquanto que águas com valor elevado de $\mathrm{pH}$, tem a tendência de formar incrustações.

De acordo com Derisio (2000), os organismos aquáticos (peixes) são geralmente adaptados às condições de neutralidade e em virtude disto, alterações bruscas no $\mathrm{pH}$ de uma água podem acarretar o desaparecimento dos seres ali presentes. Valores de pH que são afastados da neutralidade segundo Alvarez (2010, p.16) apud Von Sperling (1996), podem afetar a vida aquática e os microrganismos que são responsáveis pelo tratamento biológico de esgotos.

Os principais fatores que influenciam as variações de pH na água são o ácido carbônico, bicarbonatos, carbonatos, ácidos fortes dissociáveis, a constituição do solo, a decomposição de matéria orgânica, ácidos orgânicos, esgoto sanitário, efluentes industriais, tributários e a solubilização de gases da atmosfera.

Por fim, conforme afirmaram as autoras Ferreira \& Cunha-Santino (2014) apud Esteves (2008) e CETESB (2009):

"o pH é uma das variáveis ambientais mais importantes para a caracterização de um ambiente aquático, porém é uma das mais difíceis de interpretar e pode ser influenciada por diversos fatores tornando uma variável complexa. A elevação dos valores dessa variável pode auxiliar na precipitação dos metais pesados (que são agentes tóxicos à vida aquática) fixando-os no sedimento, influenciando assim a fisiologia de algumas espécies (CETESB, 2009)". 


\subsection{3 - A Condutividade Elétrica da Água}

Esteves et al (2011, p. 299), afirmam que a condutividade elétrica de uma solução é a capacidade desta em conduzir a corrente elétrica. Em razão disto, afirmam que, considerando que a capacidade de uma solução em conduzir a corrente elétrica é uma função da concentração dos íons presentes, é de se esperar que em soluções nas quais existam maiores concentrações iônicas, maior será a condutividade elétrica. Porém, ainda de acordo com os autores tal fenômeno ocorrerá de forma inversa quando se tratar de águas muito puras pois maior será a resistência e menor será a condutividade. Ainda de acordo com Esteves et al (2011, p. 300), em Limnologia, a condutividade elétrica da água pode ser estimada com auxílio de aparelhos chamados condutivímetros, que possuem um sensor específico onde a condutividade geralmente é determinada através de uma ponte de "Wheat stone", a qual é acoplada a dois eletrodos de platina-platinado de $1,00 \mathrm{~cm}^{2}$, distanciados entre si em 1,00 cm. Os valores de condutividade elétrica são expresso em Siemens $\left(S \cdot \mathrm{cm}^{-1}\right)$ e o inverso, a resistência elétrica em ohm ( $\Omega$ ou mho na literatura antiga), sendo $S=\Omega^{-1}$. A condutividade elétrica da água em condições naturais é expressa em $\mu \cdot \mathrm{Sm}^{-1}$, que é numericamente igual a $\mu \cdot \mathrm{mho}^{\mathrm{cm}} \mathrm{cm}^{-1}$.

Esteves (2011, p. 300), afirma que a atividade iônica de uma solução é dependente de sua temperatura (aumenta cerca de $2 \%$ a cada ${ }^{\circ} \mathrm{C}$ ), sendo que, em Limnologia adotou-se como padrão a temperatura de $25^{\circ} \mathrm{C}$, para a realização de leituras de condutividade elétrica, no passado sendo utilizados os valores como padrão de $18^{\circ} \mathrm{C}$ a $20^{\circ} \mathrm{C}$. A influência da temperatura sobre a condutividade elétrica Esteves denota que o pH (potencial Hidrogeniônico) também afeta os valores referentes a condutividade elétrica, quando este autor afirma:

\footnotetext{
"Além da temperatura, o pH da amostra pode ter influência sobre os valores da condutividade elétrica. Especialmente em águas pobres em sais solúveis e de baixos valores de $\mathrm{pH}(<5)$, o íon $\mathrm{H}^{+}$torna-se o principal responsável pelos valores de condutividade elétrica. Caso semelhante ocorre também com o íon $\mathrm{OH}^{-}$em águas muito alcalinas $(\mathrm{pH}>9)$. Assim, em amostras cujos valores de $\mathrm{pH}$ se localizam nas faixas extremas, os valores de condutividade elétrica são devidos, em grande parte, a elevadas concentrações de alguns íons em solução; dentre estes, os mais frequentes são $\mathrm{o} \mathrm{H}^{+} \mathrm{e} \mathrm{OH}$. Na prática, isto mostra que um corpo d'água rico em compostos húmicos e com pH baixo (cerca de 4) pode apresentar altos valores de condutividade elétrica da água, sem, no entanto apresentar concentrações adequadas de íons limnologicamente importantes. Nesses ecossistemas, outro fator pode conduzir a erros na determinação da condutividade elétrica: várias substâncias orgânicas são
} 
ionizáveis, podendo contribuir para a elevação do valor de condutividade da amostra".

O autor Esteves et al (2011, p. 300), dispõe que condutividade elétrica da água, constitui uma das variáveis mais importantes em Limnologia, vez que, pode fornecer importantes informações tanto em relação ao metabolismo do ecossistema aquático, como fenômenos importantes que ocorrem em sua bacia de drenagem, onde dentre essas informações destacam-se:

4.3.3.1 - Informações sobre a magnitude da concentração iônica (macronutrientes é como são chamados os íons diretamente relacionados pelos valores de condutividade elétrica em águas interiores, dos quais destacam-se o cálcio, magnésio, potássio, sódio, carbonato, sulfato, cloreto etc...), enquanto os nitratos, nitritos e especialmente o fósforo solúvel reativo tem pouca influência e o íon amônio pode ter influência somente em altas concentrações.

4.3.3.2 - A variação diária da condutividade elétrica da água fornece informações a respeito de processos importantes nos ecossistemas aquáticos, como a produção primária (redução dos valores) e decomposição (aumento dos valores).

4.3.3.3 - A condutividade elétrica pode ajudar a detectar fontes poluidoras nos ecossistemas aquáticos.

4.3.3.4 - As diferenças geoquímicas nos afluentes do rio principal ou de um lago podem ser facilmente avaliadas com auxílio de medidas da condutividade elétrica.

Por fim, Esteves et al (2011, p. 301), afirmam que em regiões tropicais, os valores de condutividade elétrica em ambientes aquáticos, estão mais relacionados com as características geoquímicas da região onde se localizam e com as condições climáticas (estação seca e de chuva), mas podem ser também influenciados pelo estado trófico, principal mente em ambientes de influência antrópica. 


\section{4 - A Metodologia utilizada na pesquisa}

No presente estudo, utilizamos a Revisão Bibliográfica e Pesquisa Documental, acerca do tema, por meio de Obras Literárias (Livros e Revistas acadêmicas), Teses de Doutorado, Dissertações de Mestrado, Trabalhos de Conclusão de Curso e Artigos Científicos, efetivamente publicados. Também foi realizada uma coleta de dados, "in loco" por meio da realização de coleta de água das nascentes existentes na cidade de São Carlos, nos seguintes locais: Córrego do Tijuco Preto, Córrego da Santa Maria Madalena (Santa Maria do Leme) e Córrego do Mineirinho. Detalhes sobre a metodologia utilizada na análise da água das nascentes, podem ser observadas na Tabela 2.

Tabela 2: Tabela de variáveis, símbolos, unidades e metodologia.

\begin{tabular}{|c|c|c|c|}
\hline Variáveis & Símbolo & Unidade & Metodologia \\
\hline Temperatura & $\mathrm{T}$ & ${ }^{\circ} \mathrm{C}$ & \multirow{2}{*}{$\begin{array}{l}\text { Equipamento Portátil Digital - Phgâmetro e } \\
\text { Termometro, Aparelho: MarcalON, } \\
\text { Modelo: pH 300, Calibrado, Patrimônio USP } \\
\text { 052.010.552, Número de Série } 0000002601\end{array}$} \\
\hline $\mathrm{pH}$ & $\mathrm{pH}$ & - & \\
\hline Condutividade Elétrica & Cond. & $\mu \mathrm{S} / \mathrm{cm}$ & $\begin{array}{l}\text { Equipamento Portátil Digital - Condutivímetro } \\
\text { Aparelho: Marca ION, Modelo: Com 300, } \\
\text { Calibrado, Patrimônio USP 052.010.553, } \\
\text { Número de Série 0000001998 }\end{array}$ \\
\hline
\end{tabular}

Fonte: Tabela adaptada pelo autor, extraída da Obra de Campagna (2005, p.26)

\section{5 - RESULTADOS - META ANÁLISE HISTÓRICA DE DADOS OBTI- DOS POR OUTROS PESQUISADORES}

Para a presente Dissertação, inicialmente foi realizada uma "meta análise" histórica em relação aos dados que foram obtidos por pesquisadores em diferentes épocas, da qualidade da água dos córregos do Tijuco Preto, Santa Maria Madalena e Mineirinho da cidade de São Carlos, cujos resultados obtidos nas pesquisas bibliográficas (documentais) realizadas, foram os seguintes: 


\section{$\underline{5.1 \text { - Córrego do Tijuco Preto }}$}

\subsection{1 - Quanto ao pH (potencial Hidrogeniônico) da Água no Córrego do} Tijuco Preto:

\subsubsection{1 - Ano de 2003}

A pesquisadora Aline Fernanda Campagna, em sua Dissertação de Mestrado, realizada no ano de 2005, CAMPAGNA, (2005, p. 237) obteve os seguintes valores de $\mathrm{pH}$ em relação as águas do córrego do tijuco preto: No mês de julho verificou o $\mathrm{pH}$ de 6,98, já no mês de outubro (não realizou a coleta);

Em relação a essa meta análise realizada, tem-se os seguintes valores que foram calculados na presente pesquisa, em relação aos dados que foram obtidos pela pesquisadora:

Média: pH 6,98,

Variância: $n / d$.

Desvio Padrão: n/d.

\subsubsection{2 - Ano de 2004:}

Já em 2004, no mês de Janeiro, CAMPAGNA (2005, p.237) obteve um pH de 7,70 e no mês de abril (não realizou a coleta).

Em relação a essa meta análise realizada, tem-se os seguintes valores que foram calculados na presente pesquisa, em relação aos dados que foram obtidos pela pesquisadora:

Média: $\mathrm{pH} 7,70$,

Variância: $\mathrm{n} / \mathrm{d}$.

Desvio Padrão: n/d. 
No que se refere as amostras do $\mathrm{pH}$ que foram coletadas por CAMPAGNA (2005, p. 237), nos anos de 2003 e 2004, verifica-se um aumento no valor do $\mathrm{pH}$ do corpo d'água, que de 6,98 passou a 7,70 (aumento de 0,72 ).

\subsubsection{3 - Ano de 2008:}

No ano de 2008, o pesquisador José Augusto Fragale Baio, obteve os seguintes resultados de coletas referente ao $\mathrm{pH}$ no córrego do Tijuco Preto:

Nas coletas que foram realizadas entre marco e abril de 2008, foram obtidos por Baio (2009, p.105), os seguintes valores: No Ponto P9 (nascente do Tijuco Preto,

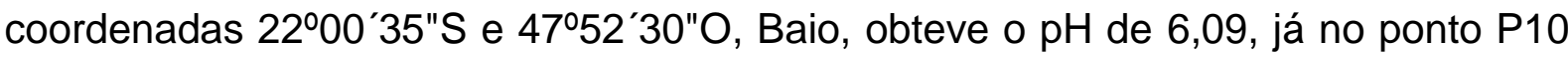
(córrego do Tijuco Preto antes de uma indústria de tapetes), coordenadas 22000'24"S e 47ํㅜㄴ 43"O, Baio, obteve o pH de 7,54, no ponto P11 (córrego do Tijuco Preto após

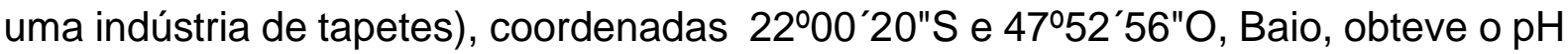
de 7,10. no ponto P12 (córrego do Tijuco Preto próximo a rodoviária do município), coordenadas 22000'14"S e 47ํ5'07"O, Baio, obteve o pH de 7,50.

Já nas coletas que foram realizadas em setembro 2008, foram obtidos por Baio (2009, p.106), os seguintes valores: No Ponto P9 (nascente do Tijuco Preto, coorde-

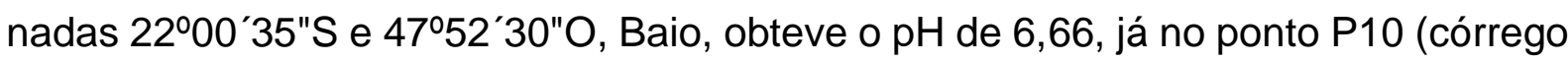
do Tijuco Preto antes de uma indústria de tapetes), coordenadas 220'24"S e 47ํ52 43"O, Baio, obteve o pH de 7,74, no ponto P11 (córrego do Tijuco Preto após uma indústria de tapetes), coordenadas 22000'20"S e 47ํำ'56"O, Baio, obteve o pH de 7,51, no ponto P12 (córrego do Tijuco Preto próximo a rodoviária do município),

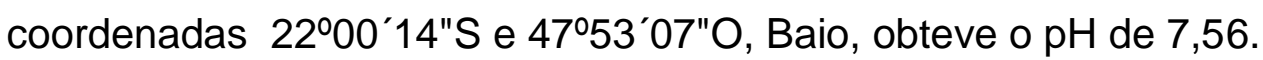

Em relação a essa meta análise realizada, tem-se os seguintes valores que foram calculados na presente pesquisa, em relação aos dados que foram obtidos pelo pesquisador:

Média: $\mathrm{pH} 7,37$.

Variância: 0,32 .

Desvio Padrão: 0,57. 
Ao analisar as coletas de $\mathrm{pH}$ que foram realizadas por BAIO (2009, p.105 e 106) no córrego do Tijuco Preto, é possível verificar que:

No ponto P09 (houve um aumento no índice de $\mathrm{pH}$, (aumento de 0,57), vez que em março/abril de 2008, o pH era 6,09 e em setembro de 2008 o pH passou a 6,66.

No ponto P10 (houve um aumento no índice de pH, (aumento de 0,20), vez que em março/abril de 2008, o pH era 7,54 e em setembro de 2008 o pH passou a 7,74 .

No ponto P11 (houve um aumento no índice de $\mathrm{pH}$, (aumento de 0,41), vez que em março/abril de 2008, o pH era 7,10 e em setembro de 2008 o pH passou a 7,51.

No ponto $\mathrm{P} 12$ (houve um aumento no índice de $\mathrm{pH}$, (aumento de 0,06), vez que em março/abril de 2008, o pH era 7,50 e em setembro de 2008 o pH passou a 7,56.

\subsection{2 - Quanto a Temperatura da Água no Córrego do Tijuco Preto:}

\subsubsection{1 - Ano de 2003:}

Em relação a temperatura da água, CAMPAGNA (2005, p.237) no que tange as as coletas de água realizadas no ano de 2003 (julho e outubro), obteve os seguintes valores, em 2003 , no mês de julho, obteve a temperatura de $21,1^{\circ} \mathrm{C}$, em outubro de 2003 (não realizou a coleta).

Em relação a essa meta análise realizada, tem-se os seguintes valores que foram calculados na presente pesquisa, em relação aos dados que foram obtidos pela pesquisadora:

Média: $21,10 \stackrel{\circ}{\mathrm{C}}$.

Variância: $\mathrm{n} / \mathrm{d}$.

Desvio Padrão: n/d. 


\subsubsection{2 - Ano de 2004:}

Quanto ao ano de 2004, no que se refere a temperatura da água do córrego do Tijuco Preto, CAMPAGNA (2005, p.237), obteve os seguintes valores, em janeiro de 2004, obteve $22,1^{\circ} \mathrm{C}$ sendo que em abril de 2004, não realizou a coleta.

Em relação a essa meta análise realizada, tem-se os seguintes valores que foram calculados na presente pesquisa, em relação aos dados que foram obtidos pela pesquisadora:

Média: $22,10^{\circ} \mathrm{C}$.

Variância: $\mathrm{n} / \mathrm{d}$.

Desvio Padrão: n/d.

Quanto aos valores de temperaturas que foram verificados por CAMPAGNA, observou-se o aumento de $1^{\circ} \mathrm{C}$ (aumento esse, devido as diferentes épocas dos anos que foram realizadas as coletas (julho/2003 - Inverno) e (janeiro/2004 - verão).

\subsubsection{3 - Ano de 2008:}

No ano de 2008, BAIO (2009, p.105-106), obteve os seguintes resultados relativos a temperatura da água no córrego do Tijuco Preto:

Nas coletas realizadas entre marco e abril de 2008, foram obtidos por BAIO (2009, p.105), os seguintes valores: No Ponto P9 (nascente do Tijuco Preto, coordenadas $22^{\circ} 00^{\prime} 35^{\prime \prime S}$ e 47ํำ'30"O, BAIO, obteve a temperatura da água de $24,4^{\circ} \mathrm{C}$, já no ponto P10 (córrego do Tijuco Preto antes de uma indústria de tapetes), coordena-

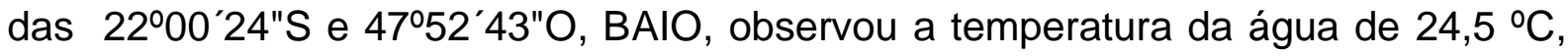
no ponto P11 (córrego do Tijuco Preto após uma indústria de tapetes), coordenadas $22^{\circ} 00^{\prime} 20^{\prime \prime S}$ e $47^{\circ} 52^{\prime} 56^{\prime \prime O}$, BAIO, obteve a temperatura de $24,7^{\circ} \mathrm{C}$ e no ponto P12 (córrego do Tijuco Preto próximo a rodoviária do município), coordenadas 220014"S

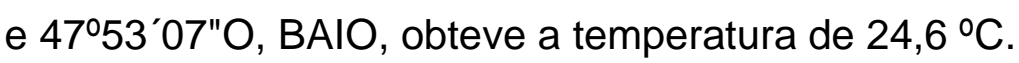

Já nas coletas que foram realizadas em setembro 2008, foram obtidos por BAIO (2009, p.106), os seguintes valores: No Ponto P9 (nascente do Tijuco Preto, 


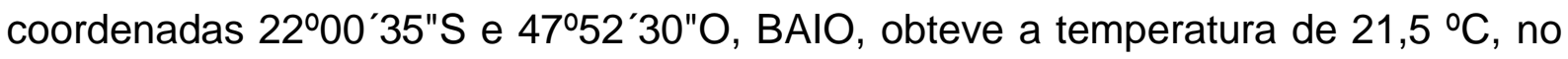
ponto P10 (córrego do Tijuco Preto antes de uma indústria de tapetes), coordenadas

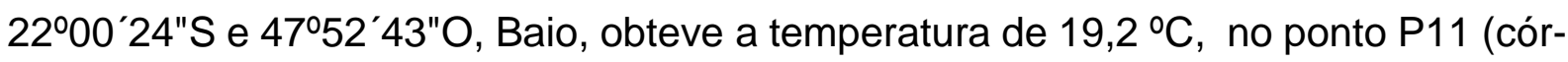
rego do Tijuco Preto após uma indústria de tapetes), coordenadas 22ํ0ㄴㅇ"S e 47ํ5'56"O, BAIO, obteve a temperatura de 18,8 ํㅡ, no ponto P12 (córrego do Tijuco

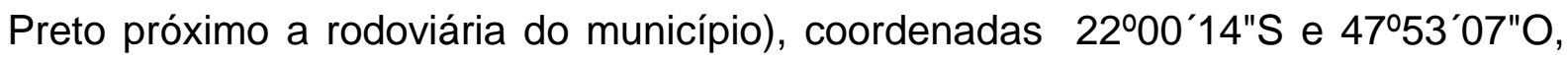
BAIO, obteve a temperatura de 18,4 ํ․

Em relação a essa meta análise realizada, tem-se os seguintes valores que foram calculados na presente pesquisa, em relação aos dados que foram obtidos pela pesquisadora:

Média: $22,01^{\circ} \mathrm{C}$.

Variância: 8,19.

Desvio Padrão: 2,86.

Ao analisar as coletas de temperatura da água que foram realizadas por BAIO (2009, p.105 e 106) no córrego do Tijuco Preto, é possível verificar que:

No ponto P09 (houve uma diminuição da temperatura da água, (diminuição de $2,29 \stackrel{\circ}{\circ}$ ), vez que em março/abril de 2008, a temperatura da água era de $24,4 \stackrel{\circ}{\circ}$ e em setembro de 2008 a temperatura da água, diminuiu para $21,5^{\circ} \mathrm{C}$.

No ponto P10 (também houve uma diminuição da temperatura da água, (diminuição de 5,3 ${ }^{\circ} \mathrm{C}$ ), vez que em março/abril de 2008, a temperatura da água era de $24,5^{\circ} \mathrm{C}$ e em setembro de 2008 a temperatura da água, diminui para 19,2 ${ }^{\circ} \mathrm{C}$.

No ponto P11 (também houve uma diminuição da temperatura da água, (diminuição de 5,9 $\stackrel{\circ}{ } \mathrm{C}$ ), vez que em março/abril de 2008, a temperatura da água era de $24,7^{\circ} \mathrm{C}$ e em setembro de 2008 a temperatura da água, diminui para $18,8{ }^{\circ} \mathrm{C}$.

No ponto P12 (também houve uma diminuição da temperatura da água, (diminuição de $6,2^{\circ} \mathrm{C}$ ), vez que em março/abril de 2008, a temperatura da água era de 24,6 ${ }^{\circ} \mathrm{C}$ e em setembro de 2008 a temperatura da água, diminui para $18,4 \stackrel{\circ}{\circ}$. 


\subsubsection{4 - Ano de 2012:}

A pesquisadora Aline Gomes Zaffani, ZAFFANNI (2012, p.79) obteve, no dia 23 de janeiro de 2012 (ZAFFANNI (2012, p.48), as seguintes temperaturas da água do córrego do Tijuco Preto, nos seguintes pontos (pontos 6 e 7):

O ponto 6 , segundo ZAFFANI (2012, p. 52), localiza-se após a nascente do córrego do Tijuco Preto, onde de acordo com a pesquisadora, na época que foi realizada a coleta de água, apesar do entorno que foi realizada a coleta ser bem urbanizado, a área de várzea apresentava margens amplas com algumas árvores, em processo de crescimento, sem construções ou impermeabilizações), onde, na data de 23 de janeiro de 2012, ZAFFANNI (2012, p.79) obteve a temperatura da água no córrego do Tijuco Preto de $23 \stackrel{\circ}{\circ}$.

Já, o ponto 7, segundo ZAFFANI (2012, p. 52), localiza-se na junção com o córrego do Monjolinho, próximo ao campus da USP, onde, neste trecho, segundo a pesquisadora, o córrego do Tijuco encontrava-se retificado, com o canal concretado e uma estreita faixa de vegetação rasteira a qual separava o canal das ruas que passam paralelas a ele. Sendo possível observar canais de lançamento de águas pluviais e sentir um forte cheiro da presença de esgoto, a coleta no ponto 7 , foi feita na data de 23 de janeiro de 2012, onde, ZAFFANNI (2012, p.79) obteve a temperatura da água no córrego do Tijuco Preto de $26^{\circ} \mathrm{C}$.

Em relação a essa meta análise realizada, tem-se os seguintes valores que foram calculados na presente pesquisa, em relação aos dados que foram obtidos pela pesquisadora:

Média: $24,50 \stackrel{\circ}{\circ}$.

Variância: 4,50.

Desvio Padrão: 2,12. 


\subsection{3 - Quanto a Condutividade Elétrica da Água no Córrego do Tijuco Preto:}

\subsubsection{1 - Ano de 2003:}

Em relação a condutividade elétrica da água do córrego do tijuco Preto, CAMPAGNA (2005, p.237), observou os seguintes valores nas coletas de água realizadas, no mês de julho, obteve a temperatura de $21,1^{\circ} \mathrm{C}$, em outubro de 2003 (não realizou a coleta).

CAMPAGNA (2005, p. 237) observou os seguintes valores nas coletas que observaram a condutividade elétrica, no córrego do tijuco preto: Em 2003, no mês de julho, obteve $193 \mu \mathrm{S} / \mathrm{cm}$, em outubro, não coletou.

Em relação a essa meta análise realizada, tem-se os seguintes valores que foram calculados na presente pesquisa, em relação aos dados que foram obtidos pela pesquisadora:

Média: 193,0 $\mu \mathrm{S} / \mathrm{cm}$.

Variância: $\mathrm{n} / \mathrm{d}$.

Desvio Padrão: n/d.

\subsubsection{2 - Ano de 2004:}

Já em janeiro de 2004, CAMPAGNA (2005, p. 237), obteve o valor de 158 $\mu S / \mathrm{cm}$, e em abril de 2004, não realizou a coleta.

Em relação a essa meta análise realizada, tem-se os seguintes valores que foram calculados na presente pesquisa, em relação aos dados que foram obtidos pela pesquisadora:

Média: 158,0 $\mu \mathrm{S} / \mathrm{cm}$.

Variância: $\mathrm{n} / \mathrm{d}$.

Desvio Padrão: n/d. 


\subsubsection{3 - Ano de 2008:}

BAIO (2009, p.105), nas coletas para a observação da condutividade elétrica da água no córrego do Tijuco Preto, coletas estas, realizadas entre marco e abril de 2008, obteve os seguintes valores: No Ponto P9 (nascente do Tijuco Preto, coordenadas $22^{\circ} 00^{\prime} 35^{\prime \prime S}$ e $47^{\circ} 52^{\prime} 30 " \mathrm{O}$, BAIO, obteve a condutividade elétrica na de 0,183 $\mathrm{mS} / \mathrm{cm}^{-1},(183 \mu \mathrm{S} / \mathrm{cm})$, no ponto P10 (córrego do Tijuco Preto antes de uma indústria

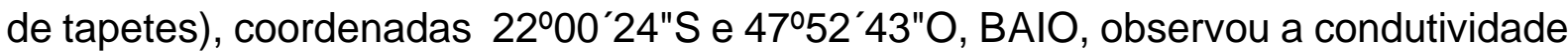
elétrica na água de $0,467 \mathrm{mS} / \mathrm{cm}^{-1},(467 \mu \mathrm{S} / \mathrm{cm})$, no ponto P11 (córrego do Tijuco

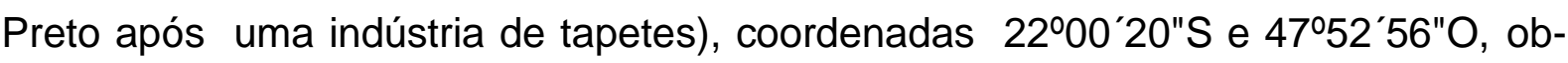
servou a condutividade elétrica na água de $0,421 \mathrm{mS} / \mathrm{cm}^{-1},(421 \mu \mathrm{S} / \mathrm{cm})$, e no ponto P12 (córrego do Tijuco Preto próximo a rodoviária do município), coordenadas

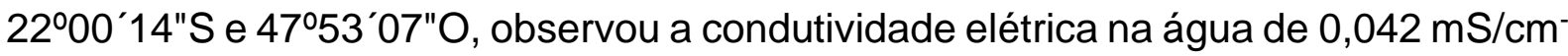
$1,(42 \mu \mathrm{S} / \mathrm{cm})$.

Já nas coletas que foram realizadas em setembro 2008, foram obtidos por BAIO (2009, p.106), os seguintes valores: No Ponto P9 (nascente do Tijuco Preto, coordenadas $22^{\circ} 00^{\prime} 35^{\prime \prime S}$ e 47ํำ'30"O, BAIO, verificou a condutividade elétrica da água de $0,183 \mathrm{mS} / \mathrm{cm}^{-1}$, (183 $\mathrm{SS} / \mathrm{cm}$ ), no ponto P10 (córrego do Tijuco Preto antes

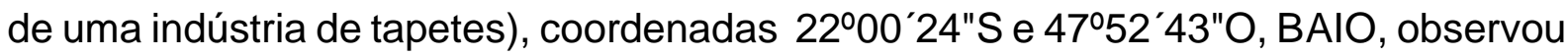
a condutividade elétrica da água, com o valor de 0,306 mS/cm-1, $(306 \mu \mathrm{S} / \mathrm{cm})$, já no ponto P11 (córrego do Tijuco Preto após uma indústria de tapetes), coordenadas

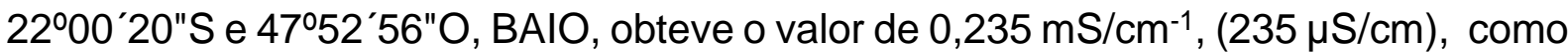
condutividade elétrica da água, no ponto P12 (córrego do Tijuco Preto próximo a rodoviária do município), coordenadas 22ํ0`14"S e 47ํ5ำ07"O, BAIO, obteve a condutividade elétrica de $0,235 \mathrm{mS} / \mathrm{cm}^{-1},(235 \mu \mathrm{S} / \mathrm{cm})$.

Em relação a essa meta análise realizada, tem-se os seguintes valores que foram calculados na presente pesquisa, em relação aos dados que foram obtidos pelo pesquisador:

Média: 259,0 $\mu \mathrm{S} / \mathrm{cm}$.

Variância: $18,787$.

Desvio Padrão: 137,07. 
Ao analisar as coletas relativas à condutividade elétrica da água que foram realizadas por BAIO (2009, p.105 e 106) no córrego do Tijuco Preto, é possível verificar que:

No ponto P09, a condutividade elétrica da água permaneceu estável em 183 $\mu \mathrm{S} / \mathrm{cm}$. (183 $\mu \mathrm{S} / \mathrm{cm}$ em março/abril de 2008 e $183 \mu \mathrm{S} / \mathrm{cm}$ em setembro de 2008).

No ponto P10 (houve uma diminuição do valor da condutividade elétrica, vez que em março/abril de 2008, o valor da condutividade elétrica da água era de 467 $\mu \mathrm{S} / \mathrm{cm}$ e em setembro de 2008, o valor relativo a condutividade elétrica da água era de $306 \mu \mathrm{S} / \mathrm{cm}$ (diminuição de $161 \mu \mathrm{S} / \mathrm{cm}$, entre os valores apurados).

No ponto P11 (também houve uma diminuição do valor da condutividade elétrica da água que antes era de $421 \mu \mathrm{S} / \mathrm{cm}$ (março/abril de 2008), onde tal valor diminui na outra coleta de água que foi realizada, para $235 \mu \mathrm{S} / \mathrm{cm}$ (em setembro de 2008), diminuição do valor de $186 \mu \mathrm{S} / \mathrm{cm}$ de condutividade elétrica da água, entre as coletas realizadas naquele ponto $(\mathrm{P} 11)$.

No ponto P12 (também houve um aumento muito grande no valor da condutividade elétrica da água , vez que em março/abril de 2008, a condutividade elétrica da água que foi observada por Baio (2009, p. 105) era de $42 \mu \mathrm{S} / \mathrm{cm}$, já em setembro de 2008, o valor da condutividade elétrica da água observado por Baio, foi de $235 \mu \mathrm{S} / \mathrm{cm}$, ou seja, um aumento no valor da condutividade elétrica de $193 \mu \mathrm{S} / \mathrm{cm}$.

\section{$\underline{5.2 \text { - Córrego Santa Maria Madalena }}$}

5.2.1 - Quanto ao pH (potencial Hidrogeniônico), da Água no Córrego Santa Maria Madalena:

\subsubsection{1 - Ano de 2003:}

No que se refere aos valores de $\mathrm{pH}$ (potencial Hidrogeniônico), obtidos no córrego Santa Maria Madalena por CAMPAGNA (205, p.237), no ano de 2003, foi verificado o valor de pH de 5,69 em julho, e no mês de outubro, não foi coletado. 
Em relação a essa meta análise realizada, tem-se os seguintes valores que foram calculados na presente pesquisa, em relação aos dados que foram obtidos pela pesquisadora:

Média: $\mathrm{pH}$ 5,69.

Variância: $n / d$.

Desvio Padrão: n/d.

\subsubsection{2 - Ano de 2004:}

No ano de 2004, no mês de janeiro, foi observado o valor de 5,06, sendo que em abril não foi coletado.

Em relação a essa meta análise realizada, tem-se os seguintes valores que foram calculados na presente pesquisa, em relação aos dados que foram obtidos pela pesquisadora:

Média: $\mathrm{pH}$ 5,06.

Variância: $\mathrm{n} / \mathrm{d}$.

Desvio Padrão: $n / d$.

Em relação as coletas de água realizadas por CAMPAGNA (2005, p.237) e possível perceber ao se verificar os valores obtidos nos anos das coletas realizadas, que houve uma ligeira diminuição dos valores relativos ao pH, de 5,69 em 2003, para 5,06 em 2004, indicando uma maior acidificação da água do corpo d'água.

\subsubsection{3 - Ano de 2008:}

BAIO (2009, p.105-106), obteve os seguintes resultados de coletas referente ao $\mathrm{pH}$ no córrego Santa Maria Madalena:

Nas coletas que foram realizadas entre marco e abril de 2008, BAIO (2009, p.105), obteve os seguintes valores: No Ponto P7 (Nascente do Córrego Santa Maria Madalena - Fazenda Salsalito, coordenadas 2158'05"S e 47ํ5ㄴ11"O, BAIO (2009, p.105), obteve o pH de 6,82, e no ponto P8 (córrego Santa Maria Madalena dentro do 
perímetro urbano), coordenadas 21ํ5’39"S e 47ํ5ㄴ13"O, BAIO (2009, p.105), obteve o pH de 6,78.

Já nas coletas que foram realizadas em setembro 2008, foram obtidos por BAIO (2009, p.106), os seguintes valores:

No Ponto P7 (Nascente do Córrego Santa Maria Madalena - Fazenda Salsalito,

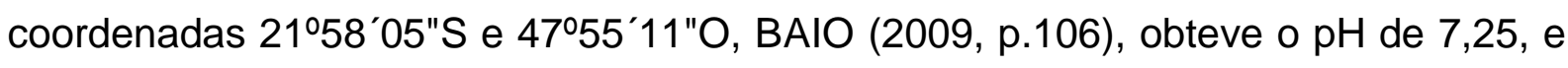
no ponto P8 (córrego Santa Maria Madalena dentro do perímetro urbano), coordenadas 2159’39"S e 47ํ5'13"O, BAIO (2009,p.106), obteve o pH de 6,88.

Em relação a essa meta análise realizada, tem-se os seguintes valores que foram calculados na presente pesquisa, em relação aos dados que foram obtidos pelo pesquisador:

Média: $\mathrm{pH} 6,93$.

Variância: 0,05.

Desvio Padrão: 0,22.

Ao analisar as coletas de pH que foram realizadas por BAIO (2009, p.105 e 106) no córrego Santa Maria Madalena, é possível verificar que:

No ponto P07 (houve um aumento no índice de $\mathrm{pH}$, (aumento de 0,43), vez que em março/abril de 2008, o pH era 6,82 e em setembro de 2008 o pH passou a 7,25.

No ponto P8 (houve um aumento no índice de $\mathrm{pH}$, (aumento de 0,10), vez que em março/abril de 2008, o pH era 6,78 e em setembro de 2008 o pH passou a 6,88.

\subsection{2 - Quanto a Temperatura da Água no Córrego Santa Maria Madalena:}

\subsubsection{1 - Ano de 2003:}

CAMPAGNA (2005, p. 237), obteve os seguintes valores relativos à temperatura que foi apurada, em 2003, no mês de julho, $17,5^{\circ} \mathrm{C}$. 
Em relação a essa meta análise realizada, tem-se os seguintes valores que foram calculados na presente pesquisa, em relação aos dados que foram obtidos pela pesquisadora:

Média: $17,50 \stackrel{\circ}{\mathrm{C}}$.

Variância: $\mathrm{n} / \mathrm{d}$.

Desvio Padrão: $n / d$.

\subsubsection{2 - Ano de 2004:}

No ano de 2004, CAMPAGNA (2005, p. 237), em janeiro, obteve $21,2{ }^{\circ} \mathrm{C}$ e em abril, não coletou.

Em relação a essa meta análise realizada, tem-se os seguintes valores que foram calculados na presente pesquisa, em relação aos dados que foram obtidos pela pesquisadora:

Média: $21,20 \stackrel{\circ}{ } \mathrm{C}$.

Variância: $\mathrm{n} / \mathrm{d}$.

Desvio Padrão: n/d.

\subsubsection{3 - Ano de 2008:}

BAIO (2009, p.105-106), obteve os seguintes resultados de coletas referente ao a temperatura da água no córrego Santa Maria Madalena:

Nas coletas que foram realizadas entre marco e abril de 2008, BAIO (2009, p.105), obteve os seguintes valores: No Ponto P7 (Nascente do Córrego Santa Maria

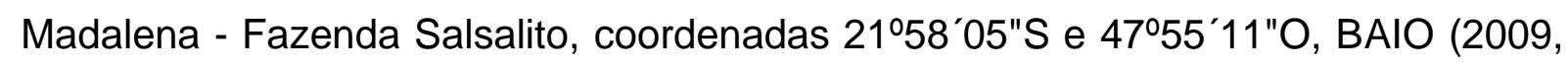
p.105), obteve a temperatura da água de $32,2{ }^{\circ} \mathrm{C}$, e no ponto $\mathrm{P} 8$ (córrego Santa Maria Madalena dentro do perímetro urbano), coordenadas 21059'39"S e 475ㄴ'13"O, BAIO (2009, p.105), obteve a temperatura da água de $25,1^{\circ} \mathrm{C}$. 
Já nas coletas que foram realizadas em setembro 2008, foram obtidos por BAIO (2009, p.106), os seguintes valores:

No Ponto P7 (Nascente do Córrego Santa Maria Madalena - Fazenda Salsalito,

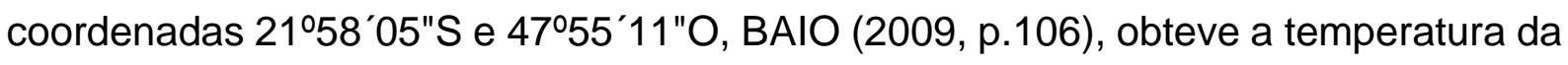
água de 25,5 ํㅡ e no ponto P8 (córrego Santa Maria Madalena dentro do perímetro urbano), coordenadas 21ำ59’39"S e 47ํ5'13"O, BAIO (2009,p.106), obteve a temperatura da água de $20,4 \stackrel{\circ}{\circ}$.

Em relação a essa meta análise realizada, tem-se os seguintes valores que foram calculados na presente pesquisa, em relação aos dados que foram obtidos pelo pesquisador:

Média: $25,80 \stackrel{\circ}{\mathrm{C}}$.

Variância: 23,57.

Desvio Padrão: 4.85.

Ao analisar as coletas de temperatura da água que foram realizadas por BAIO (2009, p.105 e 106) no córrego Santa Maria Madalena, é possível verificar que:

No ponto P07 (houve uma diminuição na temperatura da água de $6,7^{\circ} \mathrm{C}$ ), vez que em março/abril de 2008, a temperatura da água era $32,2{ }^{\circ} \mathrm{C}$ e em setembro de 2008 a temperatura da água passou a 25,5 ํ․

No ponto P8 (houve uma diminuição na temperatura da água de $4,7 \stackrel{\circ}{\circ}$ ), vez que em março/abril de 2008, a temperatura da água era $25,1^{\circ} \mathrm{C}$ e em setembro de 2008 a temperatura da água passou a $20,4 \stackrel{\circ}{ } \mathrm{C}$.

\subsubsection{4 - Ano de 2012:}

A pesquisadora Aline Gomes Zaffani, ZAFFANI (2012, p.79), no ano de 2012, na data de 23 de janeiro de 2012 (ZAFFANNI (2012, p.48), obteve as seguintes temperaturas da água no Córrego Santa Maria Madalena, nos seguintes pontos de amostragem (pontos 4 e 5):

O ponto 4, segundo ZAFFANI, (2012, p.51) localiza-se após as nascentes, próximo a Rodovia Washington Luiz, antes da urbanização. Neste ponto (ponto 4), ZAFFANI (2012, p. 79), obteve a temperatura da água de 21,5으. 
Já o ponto 5, de acordo com ZAFFANI (2012, p. 51), localiza-se antes da junção com o Córrego do Monjolinho: onde segundo a pesquisadora a várzea apresentava uma faixa de vegetação rasteira e espécies arbóreas, sendo que no ponto 5 , ZAFFANI (2012, p. 51), obteve a temperatura da água de $22,5^{\circ} \mathrm{C}$.

Em relação a essa meta análise realizada, tem-se os seguintes valores que foram calculados na presente pesquisa, em relação aos dados que foram obtidos pela pesquisadora:

Média: $22^{\circ} \mathrm{C}$.

Variância: 0,50.

Desvio Padrão: 0,71.

\subsection{3 - Quanto a Condutividade Elétrica da Água do Córrego Santa Maria} Madalena:

\subsubsection{1 - Ano de 2003:}

Quanto a condutividade elétrica no ano de 2003, da água do córrego Santa Maria Madalena, CAMPAGNA (2005, p.237), obteve em julho de 2003, a condutividade elétrica da água de 23,0 $\mu \mathrm{S} / \mathrm{cm}$.

Em relação a essa meta análise realizada, tem-se os seguintes valores que foram calculados na presente pesquisa, em relação aos dados que foram obtidos pela pesquisadora:

Média: $23 \mu \mathrm{S} / \mathrm{cm}$.

Variância: $\mathrm{n} / \mathrm{d}$.

Desvio Padrão: n/d. 


\subsubsection{2. - Ano de 2004:}

Já no ano de 2004, CAMPAGNA (2005, p.237), obteve em janeiro, o valor referente a condutividade elétrica da água de $22 \mu \mathrm{S} / \mathrm{cm}$.

Em relação a essa meta análise realizada, tem-se os seguintes valores que foram calculados na presente pesquisa, em relação aos dados que foram obtidos pela pesquisadora:

Média: $22 \mu \mathrm{S} / \mathrm{cm}$.

Variância: $\mathrm{n} / \mathrm{d}$.

Desvio Padrão: n/d.

\subsubsection{3 - Ano de 2008:}

BAIO (2009, p.105-106), obteve os seguintes resultados de coletas referente ao a temperatura da água no córrego Santa Maria Madalena:

Nas coletas que foram realizadas entre marco e abril de 2008, BAIO (2009, p.105), obteve os seguintes valores: No Ponto P7 (Nascente do Córrego Santa Maria

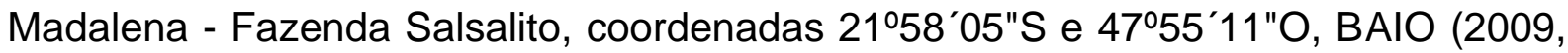
p.105), obteve o valor referente a condutividade elétrica da água de $0,013 \mathrm{mS} / \mathrm{cm}^{-1}$ (13 $\mu \mathrm{S} / \mathrm{cm}$ ), e no ponto P8 (córrego Santa Maria Madalena dentro do perímetro ur-

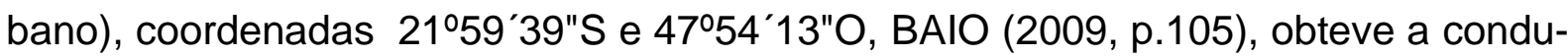
tividade elétrica da água de $0,030 \mathrm{mS} / \mathrm{cm}^{-1}(30 \mu \mathrm{S} / \mathrm{cm})$, .

Já nas coletas que foram realizadas em setembro 2008, foram obtidos por BAIO (2009, p.106), os seguintes valores:

No Ponto P7 (Nascente do Córrego Santa Maria Madalena - Fazenda Salsalito, coordenadas $21^{\circ} 58^{\prime} 05^{\prime \prime S ~ e ~} 47^{\circ} 55^{\prime} 11^{\prime \prime O}$, BAIO (2009, p.106), obteve a condutividade elétrica da água de $0,008 \mathrm{mS} / \mathrm{cm}^{-1}(8 \mu \mathrm{S} / \mathrm{cm}$ ), e no ponto P8 (córrego Santa Maria Madalena dentro do perímetro urbano), coordenadas 21ํ5'39"S e 47ํ5'13"O, BAIO (2009,p.106), obteve a condutividade elétrica da água de $0,030 \mathrm{mS} / \mathrm{cm}^{-1}(30 \mu \mathrm{S} / \mathrm{cm})$. 
Em relação a essa meta análise realizada, tem-se os seguintes valores que foram calculados na presente pesquisa, em relação aos dados que foram obtidos pela pesquisadora:

Média: $20,25 \mu \mathrm{S} / \mathrm{cm}$.

Variância: 131.

Desvio Padrão: 11,44.

Ao analisar as coletas relativas a condutividade elétrica da água que foram realizadas por BAIO (2009, p.105-106) no córrego Santa Maria Madalena, é possível verificar que:

No ponto P07 (houve uma diminuição do valor da condutividade elétrica da água de $5 \mu \mathrm{S} / \mathrm{cm}$ ), visto que em março/abril de 2008, a condutividade elétrica da água era de $0,013 \mathrm{mS} / \mathrm{cm}^{-1}(13 \mu \mathrm{S} / \mathrm{cm})$, e em setembro de 2008 a condutividade elétrica da água passou a ser de $0,008 \mathrm{mS} / \mathrm{cm}^{-1}(8 \mu \mathrm{S} / \mathrm{cm})$.

No ponto P8, a condutividade elétrica da água, no córrego Santa Maria Madalena, que foi observada por BAIO (2009, p.105-106) se manteve inalterada em 0,030 $\mathrm{mS} / \mathrm{cm}^{-1}(30 \mu \mathrm{S} / \mathrm{cm})$.

\section{3 - o Córrego do Mineirinho}

\subsection{1 - Quanto ao pH (potencial Hidrogeniônico) da Água do Córrego do}

\section{Mineirinho:}

\subsubsection{1 - Ano de 2003:}

Quanto ao pH do córrego do Mineirinho, córrego este que se localiza dentro das dependências da USP, Campus 2 de São Carlos, CAMPAGNA (2005, p.237), em julho do ano de 2003, obteve o pH de 7,04 e não coletou em outubro.

Em relação a essa meta análise realizada, tem-se os seguintes valores que foram calculados na presente pesquisa, em relação aos dados que foram obtidos pela pesquisadora: 
Média: $\mathrm{pH} 7,04$.

Variância: $\mathrm{n} / \mathrm{d}$.

Desvio Padrão: $n / d$.

\subsubsection{2 - Ano de 2004:}

Já em 2004, CAMPAGNA (2005, p.237), obteve em janeiro, o pH de 6,78 na água do córrego do Mineirinho, sendo que em abril, não houve coleta.

Em relação a essa meta análise realizada, tem-se os seguintes valores que foram calculados na presente pesquisa, em relação aos dados que foram obtidos pela pesquisadora:

Média: pH 6,78.

Variância: $\mathrm{n} / \mathrm{d}$.

Desvio Padrão: n/d.

Pode-se verificar em relação aos valores de pH obtidos por CAMPAGNA (2005, p.237), em relação aos anos de 2003 e 2004, que houve uma ligeira diminuição do pH da água, a qual ficou mais ácida.

\subsection{2 - Quanto a Temperatura da Água do Córrego do Mineirinho:}

\subsubsection{1 - Ano de 2003:}

CAMPAGNA (2005, p. 237) verificou no ano de 2003, no mês de julho, a temperatura da água no córrego do mineirinho, de $19,7^{\circ} \mathrm{C}$, sendo que em outubro, não houve coleta.

Em relação a essa meta análise realizada, tem-se os seguintes valores que foram calculados na presente pesquisa, em relação aos dados que foram obtidos pela pesquisadora: 
Média: $19,7^{\circ} \mathrm{C}$.

Variância: $n / d$.

Desvio Padrão: $\mathrm{n} / \mathrm{d}$.

\subsubsection{2 - Ano de 2004:}

Já no ano de 2004, CAMPAGNA (2005, p. 237) no mês de janeiro, obteve a temperatura da água no córrego do Mineirinho de $21,2{ }^{\circ} \mathrm{C}$ e em abril de 2004, não foi colhida.

Em relação a essa meta análise realizada, tem-se os seguintes valores que foram calculados na presente pesquisa, em relação aos dados que foram obtidos pela pesquisadora:

Média: $21,2{ }^{\circ} \mathrm{C}$.

Variância: $\mathrm{n} / \mathrm{d}$.

Desvio Padrão: n/d.

\subsubsection{3 - Ano de 2012:}

A pesquisadora Aline Gomes Zaffani, ZAFFANI (2012, p.79), no ano de 2012, na data de 23 de janeiro de 2012 (ZAFFANNI (2012, p.48), obteve as seguintes temperaturas da água no córrego do Mineirinho, nos seguintes pontos de amostragem (pontos 9 e 10):

O ponto 9, segundo ZAFFANI, (2012, p.53) localiza-se dentro do campus II da USP de São Carlos, após as nascentes do córrego do Mineirinho, onde de acordo com a pesquisadora, a região montante deste ponto era caracterizada pela ocupação no entorno do córrego, incluindo as áreas próximas de nascentes, ainda segundo a pesquisadora ZAFFANI (2012, p. 53), uma das consequências dessa ocupação é a presença de grande quantidade de resíduos em diversos pontos do córrego, ainda, segundo ZAFFANI (2012, p. 53), o córrego do Mineirinho na época da pesquisa realizada, apresentava mata ciliar bem preservada ao longo do seu curso, até se unir ao córrego do Monjolinho 
No que tange a temperatura da água do córrego do Mineirinho, ZAFFANI (2012, p. 79), no ponto 9 , obteve temperatura de $21,5^{\circ} \mathrm{C}$.

Já o ponto 10, de acordo com ZAFFANI (2012, p. 53), fica localizado antes dessa confluência (antes do córrego do Monjolinho) e também foi possível observar a presença de resíduos no canal, dificultando a passagem das águas pelas tubulações, no ponto ZAFFANI (2012, p. 79), obteve a temperatura da água no córrego do Mineirinho de $24 \stackrel{\circ}{\mathrm{C}}$.

Em relação a essa meta análise realizada, tem-se os seguintes valores que foram calculados na presente pesquisa, em relação aos dados que foram obtidos pela pesquisadora:

Média: $22,75^{\circ} \mathrm{C}$.

Variância: 3,13.

Desvio Padrão: 1,77.

\subsection{3 - Quanto a Condutividade Elétrica da Água no Córrego do Mineiri-} nho:

\subsubsection{1 - Ano de 2003:}

Em referência ao Ano de 2003, CAMPAGNA (2005, p.237) quanto a condutividade elétrica da água do córrego do Mineirinho, em julho, observou o valor de 53,0 $\mu \mathrm{S} / \mathrm{cm}$, em outubro, não coletou.

Em relação a essa meta análise realizada, tem-se os seguintes valores que foram calculados na presente pesquisa, em relação aos dados que foram obtidos pela pesquisadora:

Média: $53 \mu \mathrm{S} / \mathrm{cm}$.

Variância: $n / d$.

Desvio Padrão: n/d. 


\subsubsection{2 - Ano de 2004:}

Já em 2004, CAMPAGNA (2005, p.237) quanto a condutividade elétrica da água do córrego do Mineirinho, em janeiro, observou o valor de $39 \mu \mathrm{S} / \mathrm{cm}$, sendo que em abril, não coletou.

Em relação a essa meta análise realizada, tem-se os seguintes valores que foram calculados na presente pesquisa, em relação aos dados que foram obtidos pela pesquisadora:

Média: $39 \mu \mathrm{S} / \mathrm{cm}$.

Variância: $\mathrm{n} / \mathrm{d}$.

Desvio Padrão: n/d.

Em relação as diferentes épocas que foram realizadas as coletas, anos de 2003 e 2004, é possível observar uma queda de $14 \mu \mathrm{S} / \mathrm{cm}$, na condutividade elétrica da água de um ano para outro $(2003(53 \mu \mathrm{S} / \mathrm{cm})$ para $2004(39 \mu \mathrm{S} / \mathrm{cm}))$.

\section{6 - RESULTADOS DA ANÁLISE ATUAL DOS CÓRREGOS}

\section{1 - O Córrego do Tijuco Preto}

Para análise atual (2018) das águas do córrego do Tijuco Preto, foram escolhidos 3 pontos para a coleta das águas, pontos esses à saber:

6.1.1 - Ponto 1 - (Rotatória próxima a USP, campus 1), 220ㅜ" Latitude Sul, 4753'59", Longitude Oeste, 807 metros de Altitude. No dia 14/11/2018, a coleta foi realizada às $15 \mathrm{H} 04$, no dia $28 / 11 / 2018$, a coleta foi realizada às $13 \mathrm{H} 46$.

No que se refere aos valores de dados obtidos, nas coletas de água realizadas, foram observados os seguintes valores:

pH: 7,4 (14/11/2018), 8,1 (28/11/2018). 
Temperatura: $27^{\circ} \mathrm{C}\left(14 / 11 / 2018\right.$, tempo chuva moderada), $30^{\circ} \mathrm{C}(28 / 11 / 2018$, tempo ensolarado).

Condutividade Elétrica: $60 \mu \mathrm{S} / \mathrm{cm}$ (14/11/2018), $203 \mu \mathrm{S} / \mathrm{cm}(28 / 11 / 2018)$.

A Figura 10, foto a seguir elencada, trás a imagem do local que foi realizada a coleta de água no ponto 1, mostrando as características do corpo d'água, no caso 0 córrego do Tijuco Preto. Tal imagem, refere-se a coleta realizada em 14/11/2018 e demonstra o córrego do Tijuco Preto, que fica em frente o campus I, da USP de São Carlos, córrego este, o qual foi canalizado e recebe o escoamento pluvial, sendo que, tal fato aliado a retirada da vegetação ribeirinha a qual ficava inserida junto ao rio, acabou prejudicando a qualidade da água do referido córrego, que nas amostragens realizadas, principalmente na segunda amostragem apresentou elevada quantidade de sais na água, face o valor da condutividade elétrica apresentada, $203 \mu \mathrm{S} / \mathrm{cm}$ (28/11/2018), o que indica uma água poluída.

Figura 10: Fotografia da coleta realizada no ponto 1 (em 14/11/2018)

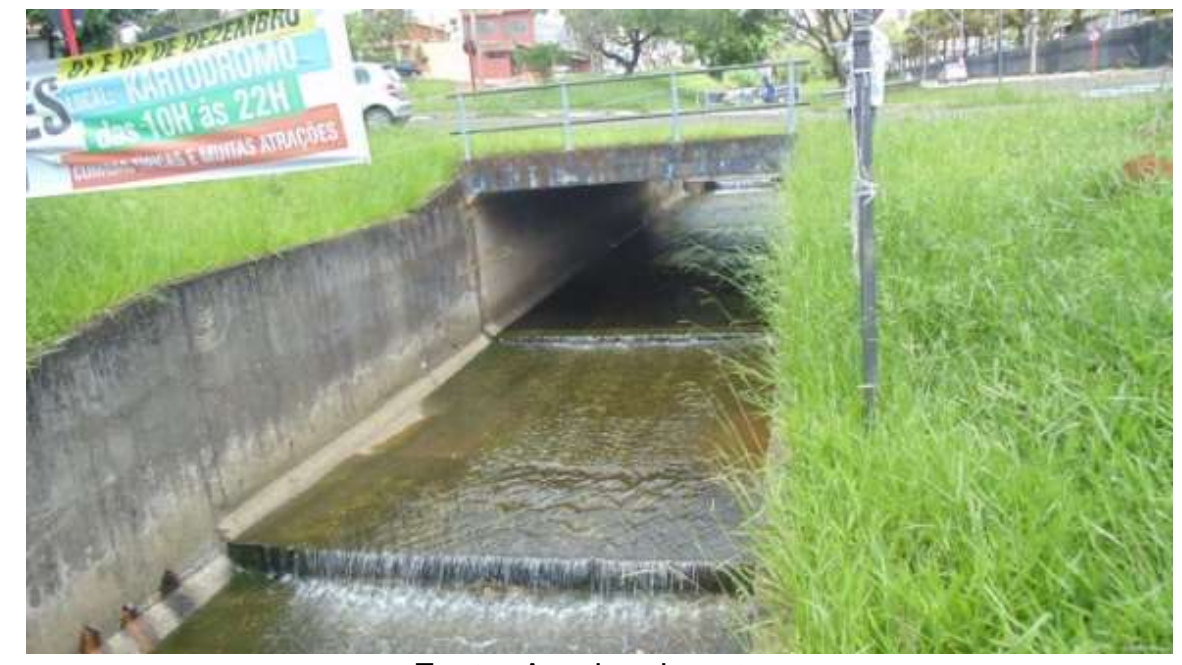

Fonte: Arquivo do autor.

6.1.2 - Ponto 2 - (Em frente a USP, campus 1), 220ㅇ'8" Latitude Sul, 47ํ53'54", Longitude Oeste, 807 metros de Altitude. No dia 14/11/2018, a coleta foi realizada às $15 \mathrm{H} 16$, no dia 28/11/2018, a coleta foi realizada às $13 \mathrm{H} 57$.

No que se refere aos valores de dados obtidos, nas coletas de água realizadas, foram observados os seguintes valores: 
pH: 7,3 (14/11/2018), 7,93 (28/11/2018).

Temperatura: $2{ }^{\circ}{ }^{\circ} \mathrm{C}\left(14 / 11 / 2018\right.$, tempo chuva moderada), $30 \stackrel{\circ}{ }{ }^{\circ}(28 / 11 / 2018$, tempo ensolarado),

Condutividade Elétrica: $89 \mu \mathrm{S} / \mathrm{cm}$ (14/11/2018), $203 \mu \mathrm{S} / \mathrm{cm}$ (28/11/2018).

6.1.3 - Ponto 3 - (para frente da entrada USP, campus 1, em cima de uma passarela de madeira amarela), 22ㅇ 0' 12" Latitude Sul, 47은 53' 46", Longitude Oeste, 822 metros de Altitude. No dia 14/11/2018, a coleta foi realizada às $15 \mathrm{H} 29$, no dia $28 / 11 / 2018$, a coleta foi realizada às $14 \mathrm{H} 10$.

No que se refere aos valores de dados obtidos, nas coletas de água realizadas, foram observados os seguintes valores:

pH: 7,38 (14/11/2018), 7,65 (28/11/2018).

Temperatura: $26^{\circ} \mathrm{C}\left(14 / 11 / 2018\right.$, tempo chuva moderada), $28^{\circ} \mathrm{C}(28 / 11 / 2018$, tempo ensolarado).

Condutividade Elétrica: $117 \mu \mathrm{S} / \mathrm{cm}(14 / 11 / 2018), 203 \mu \mathrm{S} / \mathrm{cm}(28 / 11 / 2018)$.

A Figura 11, a seguir referenciada, demonstra a coleta de água, sendo realizada no Ponto 3, do córrego do Tijuco Preto, bem como o fundo do córrego concretado.

Figura 11: Visão geral atual do Córrego Tijuco Preto

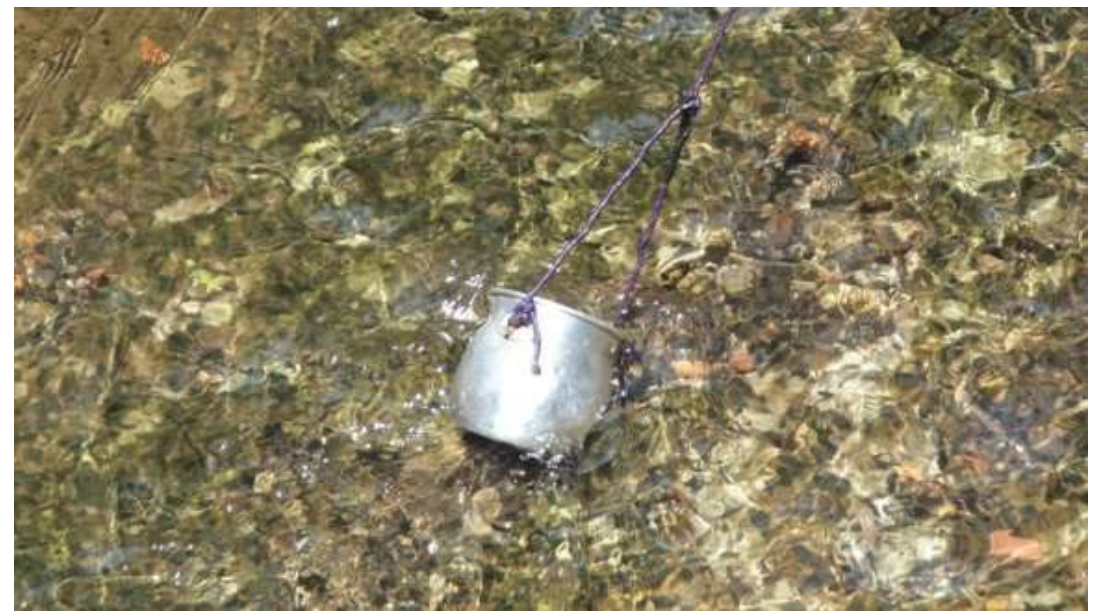

Fonte: Arquivo do autor. 
Em relação a essas análises realizadas (Pontos 1, 2 e 3), no que se refere ao pH da água do córrego do Tijuco Preto, tem-se os seguintes valores de média, variância e desvio padrão, que foram calculados na presente pesquisa, em relação aos dados que foram obtidos, nesses 3 pontos:

Média de $\mathrm{pH}: 7,63$.

Variância: 0,11.

Desvio Padrão: 0,33.

Já, no tocante a Temperatura da água do córrego do Tijuco Preto, tem-se os seguintes valores de média, variância e desvio padrão, que foram calculados na presente pesquisa, em relação aos dados que foram obtidos, nos 3 pontos (ponto 1, ponto 2 e ponto 3)

Média de temperatura: $28 \stackrel{\circ}{ } \mathrm{C}$.

Variância: 2,80.

Desvio Padrão: 1,67.

Por fim, quanto a condutividade elétrica da água do córrego do Tijuco Preto, tem-se os seguintes valores de média, variância e desvio padrão, que foram calculados na presente pesquisa, em relação aos dados que foram obtidos, nos 3 pontos (ponto 1, ponto 2 e ponto 3)

Média de condutividade elétrica da água: $145,83 \mu \mathrm{S} / \mathrm{cm}$

Variância: 4,247.

Desvio Padrão: 65,17.

\section{2 - Córrego Santa Maria Madalena}

Para análise atual (2018) das águas do córrego do Santa Maria Madalena, foram escolhidos 3 pontos para a coleta das águas, pontos esses à saber: 
6.2.1 - Ponto 4 - (Avenida Francisco Pereira Lopes, ao lado do posto de combustíveis "Sewal"), 22ํㅜ 0' 1" Latitude Sul, 47ํ53' 59", Longitude Oeste, 791 metros de Altitude. No dia 14/11/2018, a coleta foi realizada às $14 \mathrm{H}$, no dia $28 / 11 / 2018$, a coleta foi realizada às $12 \mathrm{H} 50$.

No que se refere aos valores de dados obtidos, nas coletas de água realizadas, foram observados os seguintes valores:

pH: 7 (14/11/2018), 6,53 (28/11/2018).

Temperatura: $26^{\circ} \mathrm{C}\left(14 / 11 / 2018\right.$, tempo chuva leve), $27^{\circ} \mathrm{C}(28 / 11 / 2018$, tempo ensolarado).

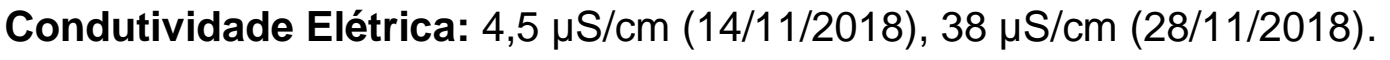

$\mathrm{Na}$ Figura 12, à seguir referenciada tem-se uma visão da vegetação (mato) e grande quantidade de árvores no córrego Santa Maria do Leme, vegetação esta que acaba influindo, melhorando a qualidade da água, face as sombras promovidas pelas árvores que contribuem para uma diminuição na temperatura e da grande quantidade de vegetação ribeirinha a qual acaba absorvendo os sais contidos na água, funcionando como um filtro natural, restabelecendo o equilíbrio natural.

Figura 12: Visão geral atual do Córrego Santa Maria Madalena

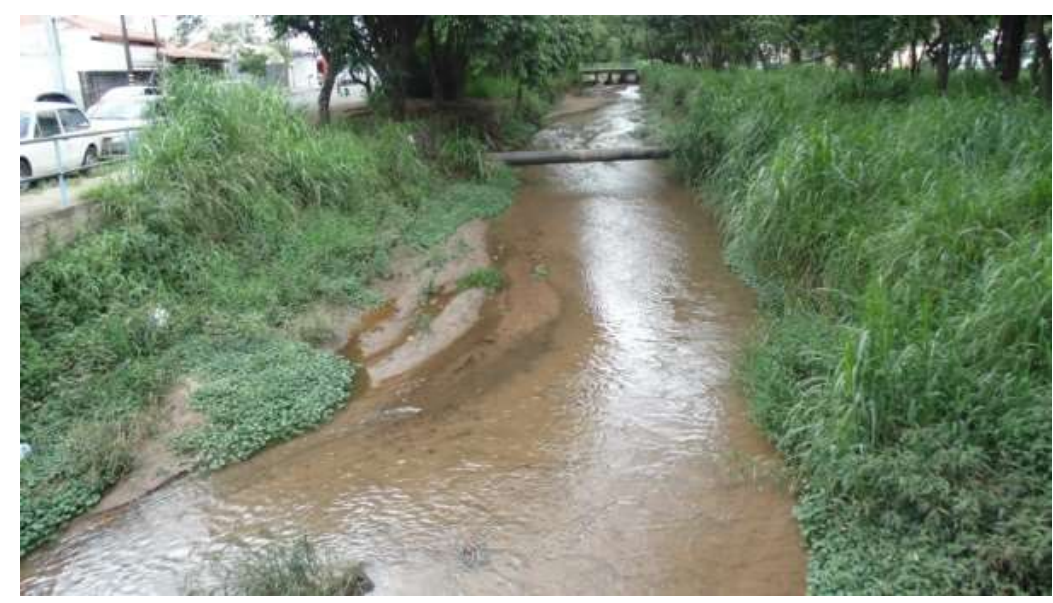

Fonte: Arquivo do autor. 
6.2.2. - Ponto 5 - (Rua Oscar de Souza Geribelo), 21ํ 59' 57" Latitude Sul, 47ำ 54' 2", Longitude Oeste, 791 metros de Altitude. No dia 14/11/2018, a coleta foi realizada às $14 \mathrm{H} 14$, no dia 28/11/2018, a coleta foi realizada às $13 \mathrm{H} 05$.

No que se refere aos valores de dados obtidos, nas coletas de água realizadas, foram observados os seguintes valores:

pH: 6,92 (14/11/2018), 6,43 (28/11/2018).

Temperatura: $27^{\circ} \mathrm{C}\left(14 / 11 / 2018\right.$, tempo chuva leve), $26^{\circ} \mathrm{C}(28 / 11 / 2018$, tempo ensolarado).

Condutividade Elétrica: $4,5 \mu \mathrm{S} / \mathrm{cm}(14 / 11 / 2018), 38 \mu \mathrm{S} / \mathrm{cm}(28 / 11 / 2018)$.

6.2.3 - Ponto 6 - (Rua Oscar de Souza Geribelo), 21ํ5' 56" Latitude Sul, 47은 54' 2", Longitude Oeste, 791 metros de Altitude. No dia 14/11/2018, a coleta foi realizada às $14 \mathrm{H} 32$, no dia 28/11/2018, a coleta foi realizada às $13 \mathrm{H} 16$.

No que se refere aos valores de dados obtidos, nas coletas de água realizadas, foram observados os seguintes valores:

pH: 7 (14/11/2018), 6,43 (28/11/2018).

Temperatura: $26 \stackrel{\circ}{\circ}\left(14 / 11 / 2018\right.$, tempo chuva moderada), $26 \stackrel{\circ}{ }{ }^{\circ}(28 / 11 / 2018$, tempo ensolarado).

Condutividade Elétrica: $51 \mu \mathrm{S} / \mathrm{cm}(14 / 11 / 2018), 38 \mu \mathrm{S} / \mathrm{cm}(28 / 11 / 2018)$.

Em relação a essas análises realizadas (pontos 4, 5 e 6), no que se refere ao pH da água do córrego Santa Maria Madalena, tem-se os seguintes valores de média, variância e desvio padrão, que foram calculados na presente pesquisa, em relação aos dados que foram obtidos, nesses 3 pontos:

Média de pH 6,72.

Variância: 0,08.

Desvio Padrão: 0,28 
Quanto a Temperatura da água do córrego Santa Maria Madalena, tem-se os seguintes valores de média, variância e desvio padrão, que foram calculados na presente pesquisa, em relação aos dados que foram obtidos, nos 3 pontos (ponto 4, ponto 5 e ponto 6$)$

Média de temperatura: $26,33^{\circ} \mathrm{C}$.

Variância: 0,27.

Desvio Padrão: 0,52.

Por fim, no que se refere a condutividade elétrica da água do córrego Santa Maria Madalena, tem-se os seguintes valores de média, variância e desvio padrão, que foram calculados na presente pesquisa, em relação aos dados que foram obtidos, nos 3 pontos (ponto 4, ponto 5 e ponto 6)

Média de condutividade elétrica da água: $29 \mu \mathrm{S} / \mathrm{cm}$

Variância: 386.

Desvio Padrão: 19,63.

\section{3 - O Córrego do Mineirinho}

Para análise atual (2018) das águas do córrego do Mineirinho, foram escolhidos 4 pontos para a coleta das águas, pontos esses à saber:

6.3.1 - Ponto 7 - (USP, campus 2, ponte de madeira, lado direito da ponte, para frente do prédio central da Administração), 2200'13" Latitude Sul, 47ํ5'51", Longitude Oeste, 820 metros de Altitude. No dia 14/11/2018, a coleta foi realizada às $16 \mathrm{H} 02$, no dia 28/11/2018, a coleta foi realizada às $10 \mathrm{H} 12$.

No que se refere aos valores de dados obtidos, nas coletas de água realizadas, foram observados os seguintes valores:

pH: 7,0 (14/11/2018), 6,54 (28/11/2018). 
Temperatura: $23^{\circ} \mathrm{C}\left(14 / 11 / 2018\right.$, tempo chuva leve, respingos), $24^{\circ} \mathrm{C}$ (28/11/2018, tempo ensolarado).

Condutividade Elétrica: $18 \mu \mathrm{S} / \mathrm{cm}$ (14/11/2018), $45 \mu \mathrm{S} / \mathrm{cm}(28 / 11 / 2018)$.

A Figura 13, à seguir referenciada, demonstra a coleta de água sendo realizada no ponto 7 no córrego do Mineirinho (dentro do campus II da USP de São Carlos), nela é possível ser observado o sedimento que se encontra no fundo do referido córrego.

Figura 13: Visão geral atual de um ponto de amostragem no Córrego Mineirinho

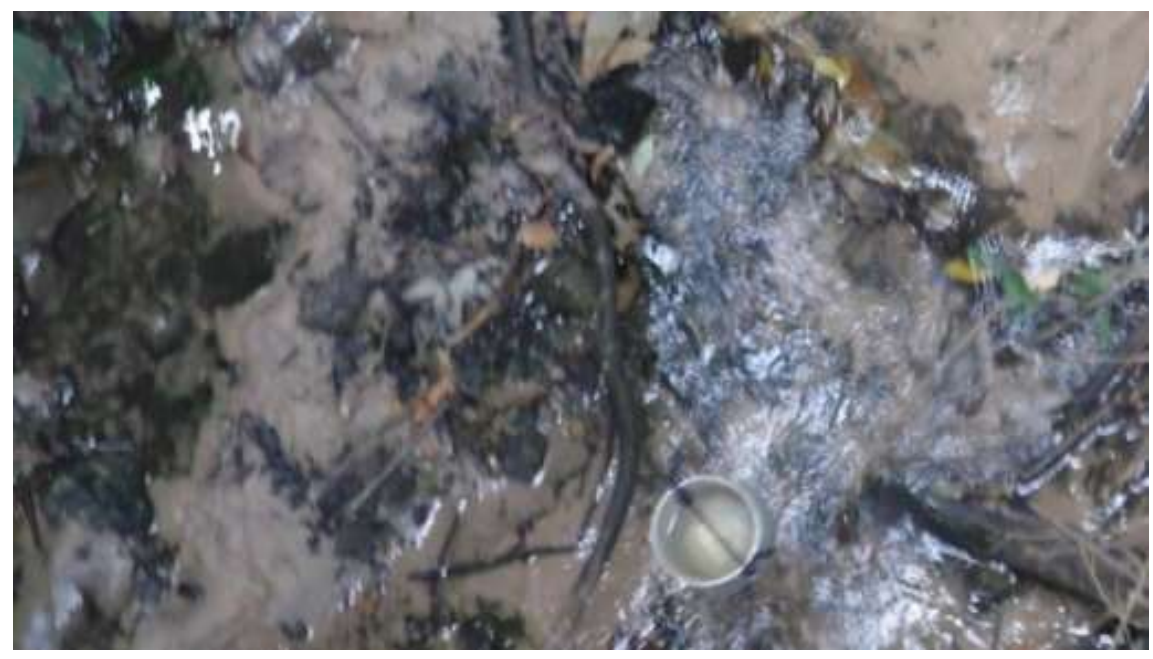

Fonte: Arquivo do autor.

6.3.2 - Ponto 8 - (USP, campus 2, ponte de madeira, lado esquerdo da ponte, em frente do prédio do Instituto de Química), 220'13" Latitude Sul, 47ํ55'50", Longitude Oeste, 820 metros de Altitude. No dia 14/11/2018, a coleta foi realizada às 16H08, no dia $28 / 11 / 2018$, a coleta foi realizada às $10 \mathrm{H} 20$.

No que se refere aos valores de dados obtidos, nas coletas de água realizadas, foram observados os seguintes valores:

pH: 6,7 (14/11/2018), 6,3 (28/11/2018).

Temperatura: $23{ }^{\circ} \mathrm{C}$ (14/11/2018, tempo chuva leve, respingos), $24{ }^{\circ} \mathrm{C}$ (28/11/2018, tempo ensolarado).

Condutividade Elétrica: $18 \mu \mathrm{S} / \mathrm{cm}$ (14/11/2018), $15 \mu \mathrm{S} / \mathrm{cm}(28 / 11 / 2018)$. 
A Figura 14, à seguir referenciada, mostra a fotografia da coleta de água no Ponto 8, no córrego do Mineirinho, dentro do campus II da USP de São Carlos, o local é difícil acesso, onde a coleta foi realizada por cima de uma ponte de madeira existente no local.

Figura 14: Visão geral atual do ponto 8, realizada no Córrego Mineirinho

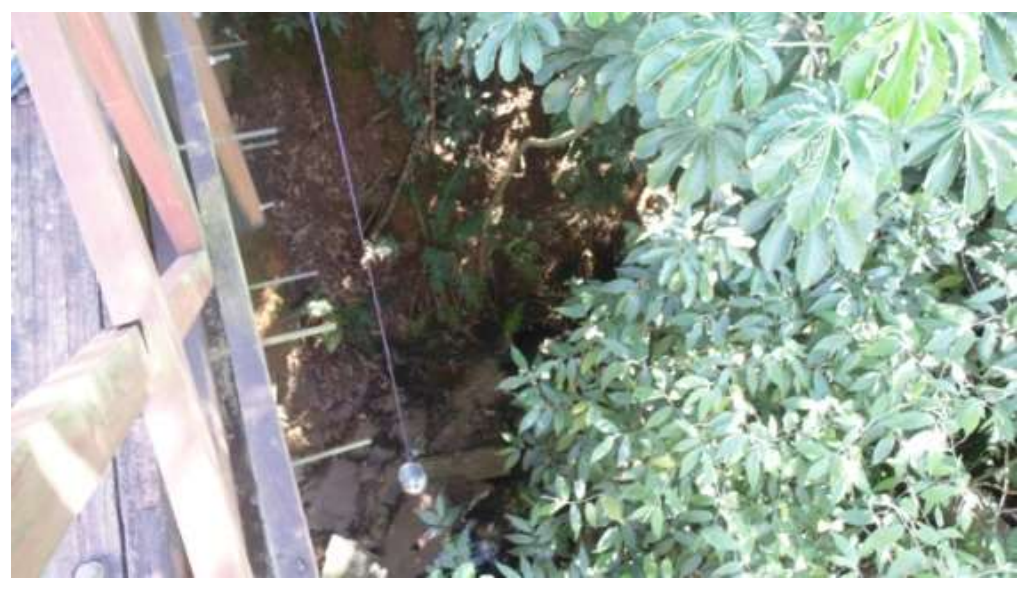

Fonte: Arquivo do autor.

6.3.3. - Ponto 9 - (USP, campus 2, ponte de madeira, lado esquerdo da ponte antes do prédio do Instituto de Química), 2159'59" Latitude Sul, 4755'42", Longitude Oeste, 824 metros de Altitude. No dia 14/11/2018, a coleta foi realizada às $16 \mathrm{H} 53$, no dia 28/11/2018, a coleta foi realizada às $10 \mathrm{H} 35$.

No que se refere aos valores de dados obtidos, nas coletas de água realizadas, foram observados os seguintes valores:

pH: 6,7 (14/11/2018), 6,8 (28/11/2018).

Temperatura: $25^{\circ} \mathrm{C}(14 / 11 / 2018$, tempo nublado), $24 \stackrel{\circ}{\circ} \mathrm{C}(28 / 11 / 2018$, tempo ensolarado).

Condutividade Elétrica: $82 \mu \mathrm{S} / \mathrm{cm}(14 / 11 / 2018), 60 \mu \mathrm{S} / \mathrm{cm}(28 / 11 / 2018)$ 
6.3.4 - Ponto 10 - (USP, campus 2, dentro da mata, presença de degradação e poluição antrópica próximo ao ponto de coleta), 21ำ59'35" Latitude Sul, 47055'52", Longitude Oeste, 843 metros de Altitude. No dia 14/11/2018, a coleta foi realizada às $17 \mathrm{H} 02$, no dia 28/11/2018, a coleta foi realizada às $10 \mathrm{H} 47$.

No que se refere aos valores de dados obtidos, nas coletas de água realizadas, foram observados os seguintes valores:

pH: 6,8 (14/11/2018), 6,61 (28/11/2018).

Temperatura: $24^{\circ} \mathrm{C}\left(14 / 11 / 2018\right.$, tempo nublado), $25^{\circ} \mathrm{C}(28 / 11 / 2018$, ensolarado).

Condutividade Elétrica: $121 \mu \mathrm{S} / \mathrm{cm}(14 / 11 / 2018), 78 \mu \mathrm{S} / \mathrm{cm}(28 / 11 / 2018)$.

A Figura 15, à seguir referenciada, demonstra a coleta de água realizada no ponto 10, no córrego do Mineirinho, ponto este, que se encontrava dentro de uma mata, a qual pela imagem do local, presumia-se que água estaria apresentado boas condições relativas a qualidade da mesma, porém face o entorno do local, em que existe uma comunidade próxima e as pessoas adentram a área do campus II da USP de São Carlos e jogam entulhos e outros materiais (lixo e outros materiais orgânicos), conforme foi presenciado e demonstrado nas Figuras 16, 17 e 18, à seguir elencadas, tais materiais acabam contaminando e poluindo o córrego d'água, no caso o córrego do Mineirinho.

Figura 15: Visão geral atual do ponto 10, realizada no Córrego Mineirinho

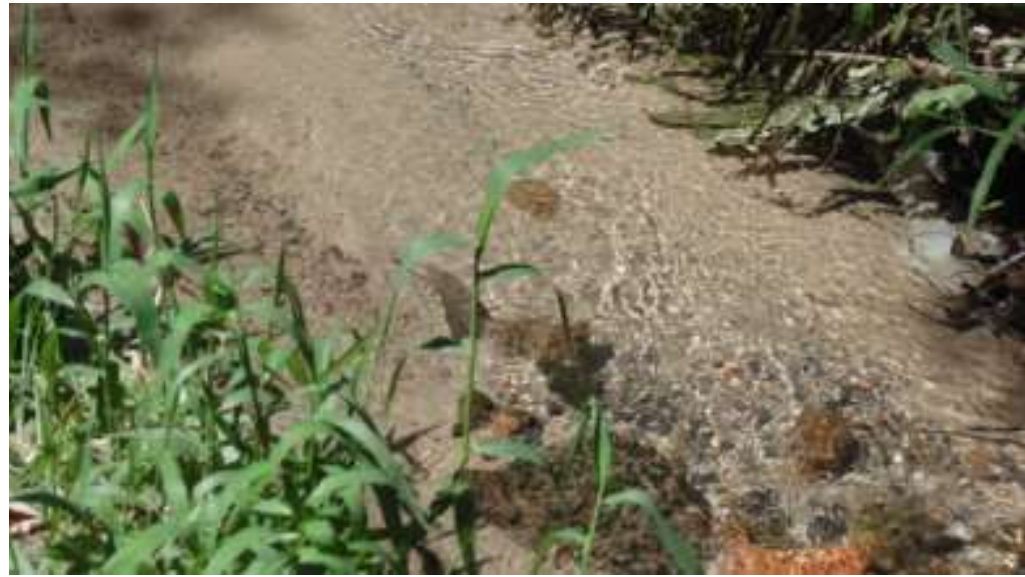

Fonte: Arquivo do autor. 
As Figuras 16, 17 e 18, a seguir referenciadas demonstram o acumulo de lixo e entulhos nos fundos da USP, Campus 2, que foram jogados indevidamente pela população (sem autorização), o que contribui para o aumento dos níveis de poluição dos mananciais de água, existentes naquele local, além de aumentarem o risco da criação naqueles locais de animais peçonhentos como aranhas, cobras e escorpiões, além do risco do acúmulo de água das chuvas, podendo tais locais se tornarem criadouros de mosquitos e outros vetores transmissores de doenças.

As Figuras 16 e 17, são fotografias que mostram o acumulo de entulhos de telhas de amianto e outros materiais que foram jogados nos fundos da USP, Campus 2, pela população.

Figura 16:

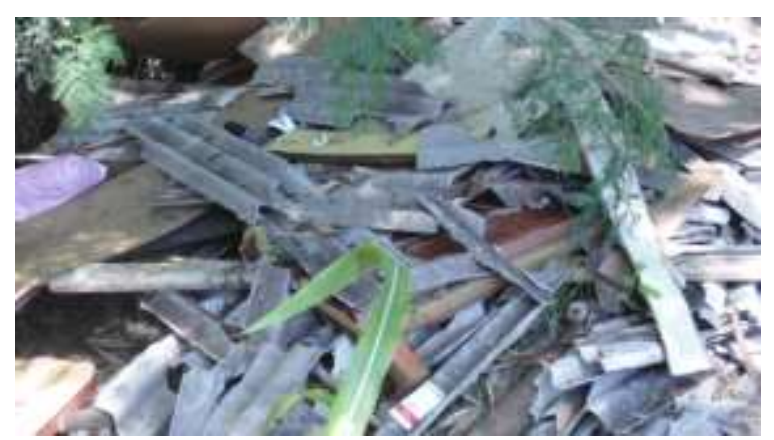

Fonte: Arquivo do autor.
Figura 17:

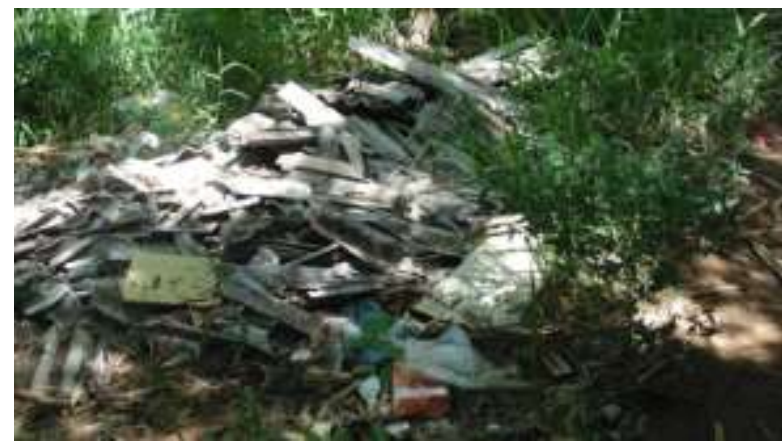

Fonte: Arquivo do autor.

A Figura 18 à seguir referenciada é uma fotografia que demonstra o acúmulo de lixo orgânico, misturado com plásticos e metais que foram jogados indevidamente pela população na área da USP, campus 2, em São Carlos. 
Figura 18: Visão geral atual do Córrego Mineirinho

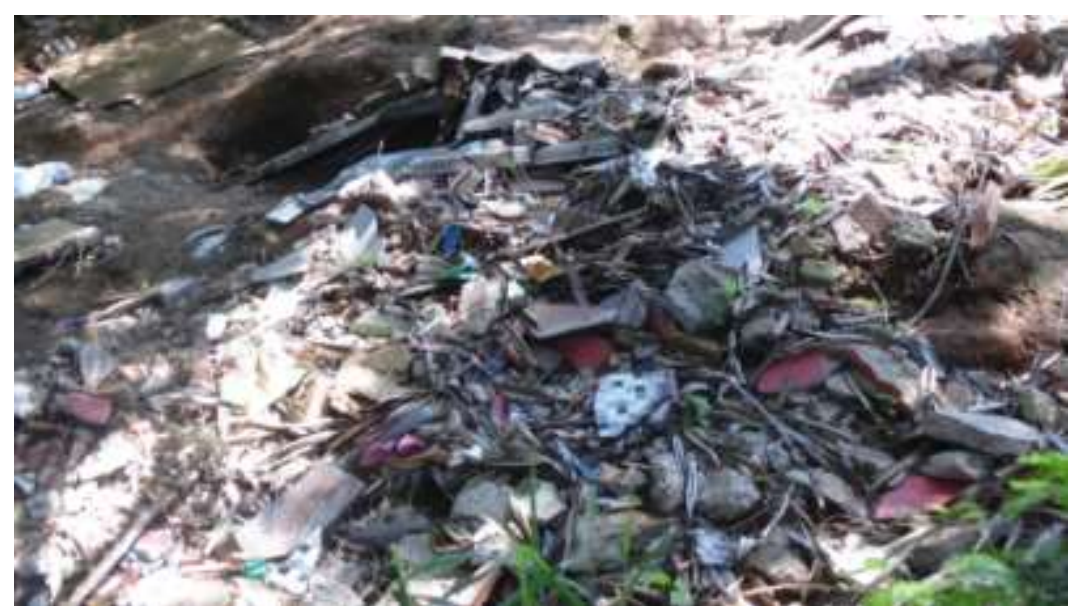

Fonte: Arquivo do autor.

Em relação a essas análises realizadas, nos pontos 7, 8, 9 e 10, no que se refere ao pH da água do córrego do Mineirinho, tem-se os seguintes valores de média, variância e desvio padrão, que foram calculados na presente pesquisa, em relação aos dados que foram obtidos, nesses 4 pontos:

Média de $\mathrm{pH}:$ 6,68.

Variância: 0,04.

Desvio Padrão: 0,21.

Quanto a Temperatura da água do córrego do Mineirinho, tem-se os seguintes valores de média, variância e desvio padrão, que foram calculados na presente pesquisa, em relação aos dados que foram obtidos, nos 4 pontos (ponto 7, ponto 8, ponto 9 e ponto 10).

Média de temperatura: $24^{\circ} \mathrm{C}$.

Variância: 0,57.

Desvio Padrão: 0,76. 
Por fim, no que se refere a condutividade elétrica da água do córrego do Mineirinho, tem-se os seguintes valores de média, variância e desvio padrão, que foram calculados na presente pesquisa, em relação aos dados que foram obtidos, nos 4 pontos (ponto 7 , ponto 8 , ponto 9 , e ponto 10 )

Média de condutividade elétrica da água: $54,63 \mu \mathrm{S} / \mathrm{cm}$

Variância: 1.439.

Desvio Padrão: 37,94.

\section{7 - RESULTADOS REFERENTES A ANÁLISE HISTÓRICA (COLETAS ANTERIORES) E ANÁLISE ATUAL (PRESENTE ESTUDO)}

Com relação aos resultados obtidos referentes as análises históricas de água pelos diversos pesquisadores em diferentes épocas nos córregos do Tijuco Preto, Santa Maria Madalena e Mineirinho, de acordo com os valores referências de $\mathrm{pH}$, Temperatura e Condutividade Elétrica, de acordo com o valor padrão (Apêndice da CETESB de Qualidade de Água), pode-se verificar:

\section{1 - O Córrego do Tijuco Preto quanto ao pH da Água}

O pH da água do córrego do Tijuco Preto variou de 6,09 (valor mínimo (Ano de 2008)) à 8,1 (valor máximo (Ano de 2018)), sendo que a média geral registrada de $\mathrm{pH}$ foi de 7,38 . Pelos dados aferidos pelos pesquisadores, é possível afirmar de acordo com os parâmetros estabelecidos dentro dos padrões de qualidade da água (Apêndice E - Significado Ambiental e Sanitário das Variáveis de Qualidade das Águas e dos Sedimentos e Metodologia Analíticas e de Amostragem - CETESB), que os valores estão dentro do aceitável para manutenção da biota em corpos d'água (pH de 6 à 9). Portanto o córrego do Tijuco Preto pela meta análise e pela análise realizadas durante o período histórico estudado, se encontra dentro da normalidade quanto os valores de $\mathrm{pH}$. 
A Figura 19, à seguir referenciada, demonstra um Gráfico com os valores referentes a média e o desvio padrão, tanto da meta análise realizada (trabalhos realizados por pesquisadores anteriores, CAMPAGNA (2005) e BAIO (2009)), quanto em relação a atual análise realizada, feito pelo corrente pesquisador TRALBACK (2020), em relação aos valores de pH da água do córrego do Tijuco Preto.

Figura 19

\section{Córrego do Tijuco Preto}

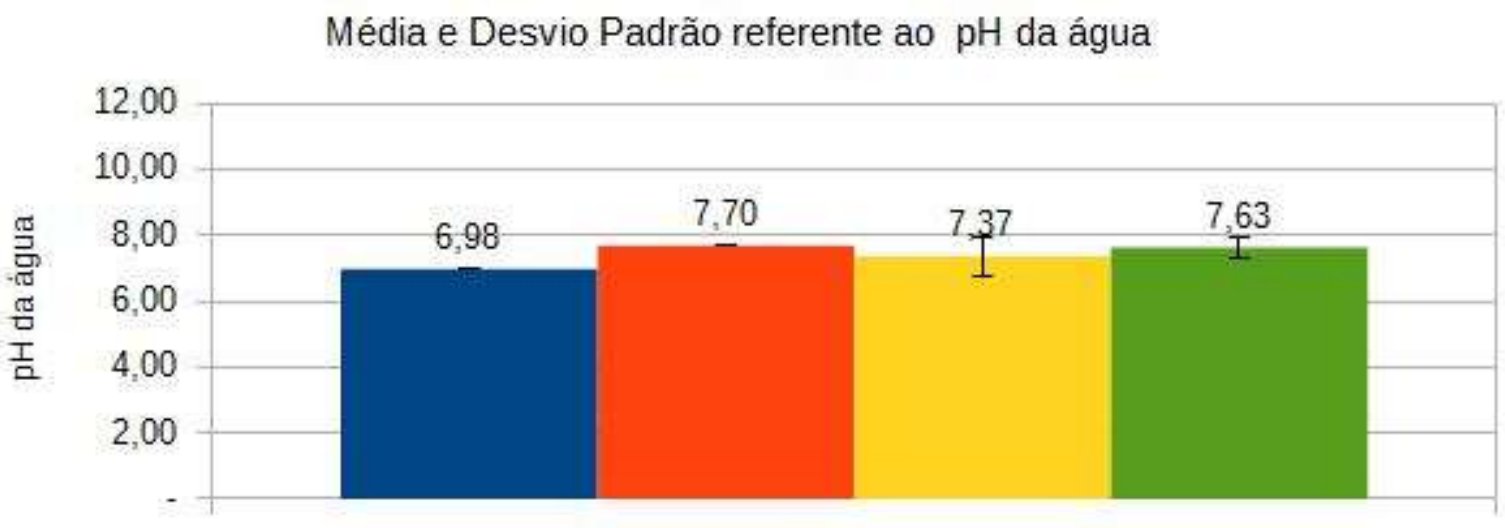

Pesquisadores

CAMPAGNA(2005) ref. ano de 2003 CAMPAGNA (2005) ref. ano de 2004 BAIO (2009) ref. ano de $2008 \quad$ wTRALBACK (2020) ref. ano de 2018

Fonte: Arquivo do autor

\section{2 - 0 Córrego do Tijuco Preto quanto a Temperatura da Água}

A temperatura da água do córrego do Tijuco Preto variou de $18,4{ }^{\circ} \mathrm{C}$ (valor mínimo (Ano de 2008)) à $30 \stackrel{\circ}{ }$ C (valor máximo (Ano de 2018)), sendo que a média geral registrada de temperatura foi de $24,24 \stackrel{\circ}{ } \mathrm{C}$. Pelos dados aferidos pelos pesquisadores, é possível afirmar de acordo com os parâmetros estabelecidos dentro dos padrões de qualidade da água (Apêndice E - Significado Ambiental e Sanitário das Variáveis de Qualidade das Águas e dos Sedimentos e Metodologia Analíticas e de Amostragem CETESB), que os valores de temperatura da água do córrego do Tijuco Preto, estão dentro do aceitável para manutenção da biota em corpos d'água. Portanto, o córrego do Tijuco Preto, pela meta análise e pela análise realizadas durante o período histórico 
estudado, se encontra dentro da normalidade quanto os valores de temperatura da água.

A Figura 20, à seguir referenciada, demonstra um Gráfico com os valores referentes a média e o desvio padrão, tanto da meta análise realizada (trabalhos realizados por pesquisadores anteriores, CAMPAGNA (2005), BAIO (2009), ZAFFANI (2012)), quanto em relação a atual análise realizada, feito pelo corrente pesquisador TRALBACK (2020), em relação aos valores de Temperatura da água do córrego do Tijuco Preto.

Figura 20

\section{Córrego do Tijuco Preto}

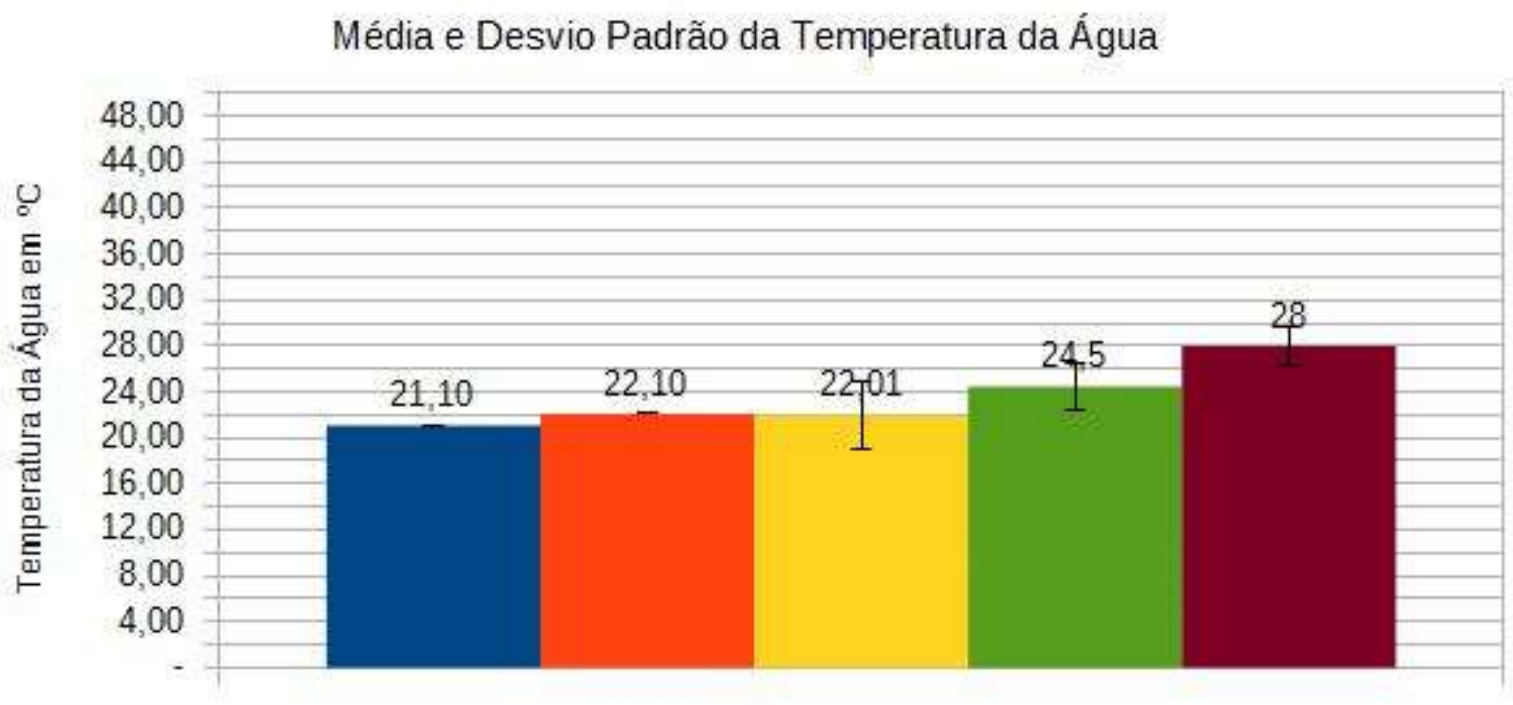

Pesquisadores

CAMPAGNA (2005) ref. ano de 2003

BAIO (2009) ref. ano de 2008

- TRALBACK (2020) ref. ano de 2018
CAMPAGNA (2005) ref. ano de 2004 m ZAFFANI (2012) ref. ano de 2012

Fonte: Arquivo do autor 


\section{3 - O Córrego do Tijuco Preto quanto a Condutividade Elétrica da Água}

A condutividade elétrica da água do córrego do Tijuco Preto variou de $60 \mu \mathrm{S} / \mathrm{cm}$ (valor mínimo (Ano de 2018)) à $467 \mu \mathrm{S} / \mathrm{cm}$ (valor máximo (Ano de 2008)), sendo que a média geral registrada de condutividade elétrica da água foi de $206 \mu \mathrm{S} / \mathrm{cm}$. Pelos dados aferidos pelos pesquisadores, é possível afirmar de acordo com os parâmetros estabelecidos dentro dos padrões de qualidade da água (Apêndice E - Significado Ambiental e Sanitário das Variáveis de Qualidade das Águas e dos Sedimentos e Metodologia Analíticas e de Amostragem - CETESB), que os valores de condutividade elétrica da água do córrego do Tijuco Preto, estão muito superiores (203 $\mu \mathrm{S} / \mathrm{cm}$ (2018) ao valor limite aceitável (100 $\mathrm{S} / \mathrm{cm}$ - Índice de referência Padrão CETESB). Portanto, o córrego do Tijuco Preto, pela meta análise e pela análise realizadas durante o período histórico estudado, embora sua poluição tenha diminuído um pouco ( $467 \mu \mathrm{S} / \mathrm{cm}$ (2008), continua poluído (203 $\mu \mathrm{S} / \mathrm{cm}$ (2018), quanto os valores de condutividade elétrica da água.

A Figura 21, à seguir referenciada, demonstra um Gráfico com os valores referentes a média e o desvio padrão, tanto da meta análise realizada (trabalhos realizados por pesquisadores anteriores, CAMPAGNA (2005) e BAIO (2009)), quanto em relação a atual análise realizada, feito pelo corrente pesquisador TRALBACK (2020), em relação aos valores de condutividade elétrica da água do córrego do Tijuco Preto. 
Figura 21

\section{Córrego do Tijuco Preto}

Média e Desvio Padrão da Condutividade Elétrica da Água

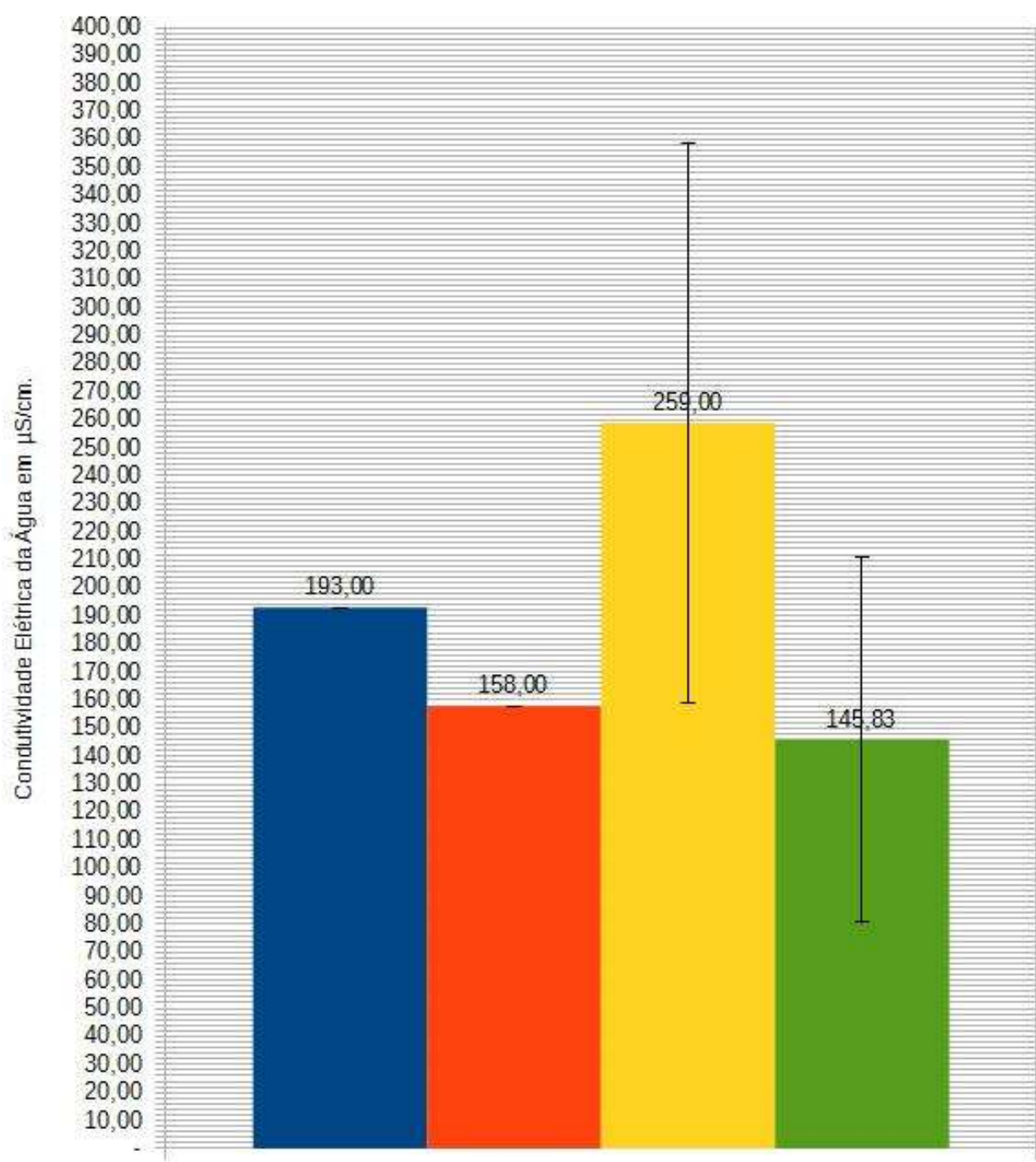

Pesquisadores

- CAMPAGNA (2005) ref. ano de 2003 -CAMPAGNA (2005) ref. ano de 2004

BAIO (2009) ref. ano de $2008 \quad$ =TRALBACK (2020) ref. ano de 2018

Fonte: Arquivo do autor 


\section{4 - O Córrego Santa Maria Madalena quanto ao pH da Água}

O pH da água do córrego do Santa Maria Madalena variou de 5,06 (valor mínimo (Ano de 2004) à 7,25 (valor máximo (Ano de 2008), sendo que a média geral registrada de $\mathrm{pH}$ foi de 6,57. Pelos dados aferidos pelos pesquisadores, é possível afirmar de acordo com os parâmetros estabelecidos para a qualidade da água (Apêndice E - Significado Ambiental e Sanitário das Variáveis de Qualidade das Águas e dos Sedimentos e Metodologia Analíticas e de Amostragem - CETESB), que os valores estão dentro do aceitável para manutenção da biota em corpos d'água ( $\mathrm{pH}$ de 6 à 9). Portanto, o córrego Santa Maria Madalena pela meta análise e pela análise realizadas durante o período histórico estudado, se encontra dentro da normalidade quanto os valores de $\mathrm{pH}$.

A Figura 22, à seguir referenciada, demonstra um Gráfico com os valores referentes a média e o desvio padrão, tanto da meta análise realizada (trabalhos realizados por pesquisadores anteriores, CAMPAGNA (2005) e BAIO (2009)), quanto em relação a atual análise realizada, feito pelo corrente pesquisador TRALBACK (2020), em relação aos valores de pH (potencial Hidrogeniônico), da água do córrego Santa Maria Madalena.

Figura 22

\section{Córrego Santa Maria Madalena}

Média e Desvio Padrão referente ao pH da Água

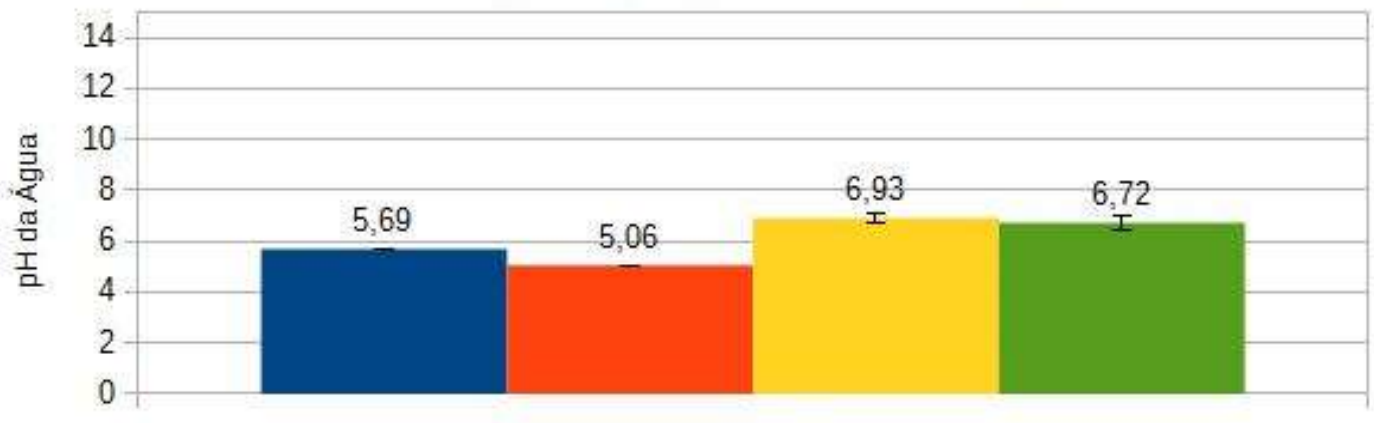

Pesquisadores

CAMPAGNA (2005) ref. ano de 2003 = CAMPAGNA (2005) ref. ano de 2004 


\section{5 - O córrego Santa Maria Madalena quanto a temperatura da água}

A temperatura da água do córrego Santa Maria Madalena variou de $17,5{ }^{\circ} \mathrm{C}$ (valor mínimo (Ano de 2003) à 32,2 ${ }^{\circ} \mathrm{C}$ (valor máximo (Ano de 2008), sendo que a média geral registrada de temperatura foi de $24,56{ }^{\circ} \mathrm{C}$. Pelos dados aferidos pelos pesquisadores, é possível afirmar de acordo com os parâmetros estabelecidos dentro dos padrões de qualidade da água (Apêndice E - Significado Ambiental e Sanitário das Variáveis de Qualidade das Águas e dos Sedimentos e Metodologia Analíticas e de Amostragem - CETESB), que os valores de temperatura da água do córrego da Santa Maria Madalena, estão dentro do aceitável para manutenção da biota em corpos d'água. Portanto, o córrego Santa Maria Madalena, pela meta análise e pela análise realizadas durante o período histórico estudado, se encontra dentro da normalidade quanto os valores de temperatura da água.

A Figura 23, à seguir referenciada, demonstra um Gráfico com os valores referentes a média e o desvio padrão, tanto da meta análise realizada (trabalhos realizados por pesquisadores anteriores, CAMPAGNA (2005), BAIO (2009) e ZAFFANI (2012), quanto em relação a atual análise realizada, feito pelo corrente pesquisador TRALBACK (2020), em relação aos valores de temperatura da água do córrego Santa Maria Madalena. 
Figura 23

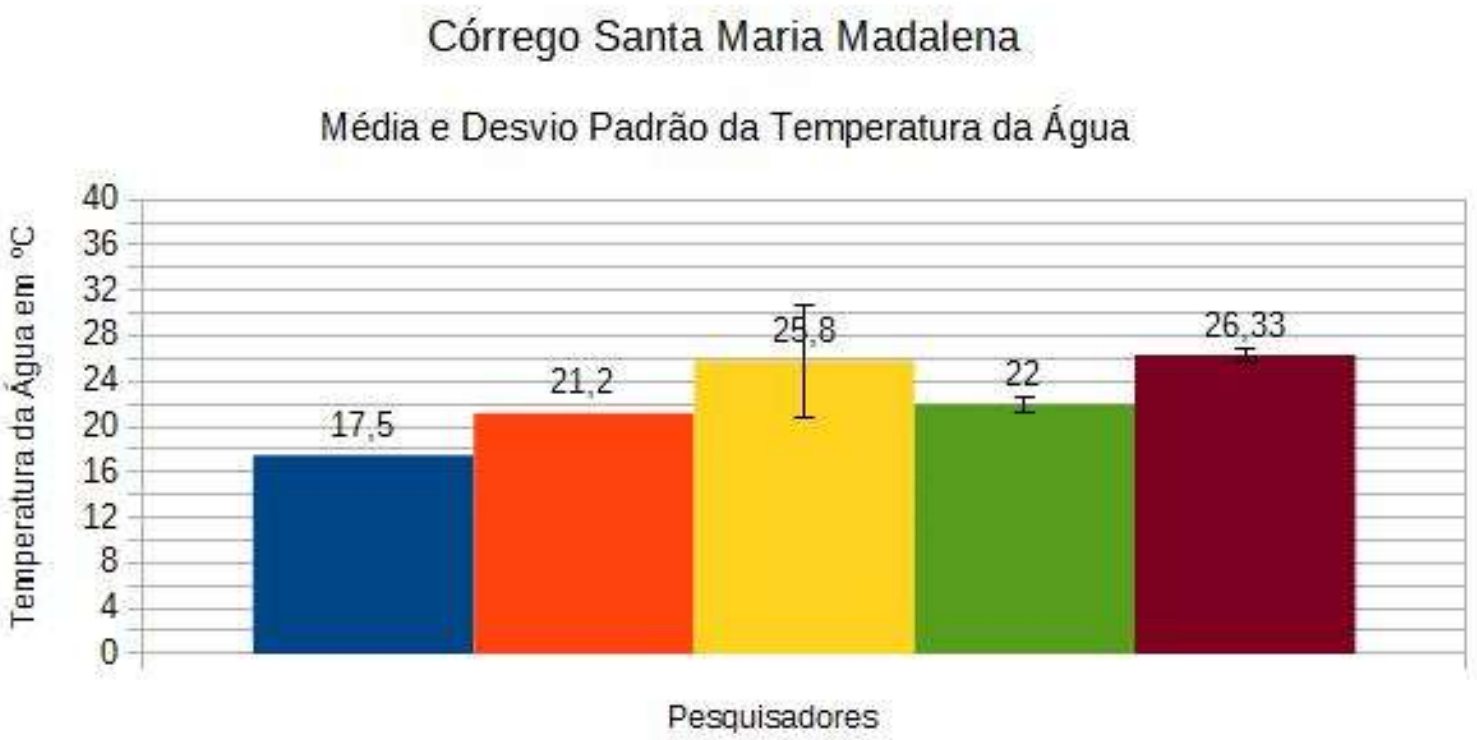

CAMPAGNA (2005) ref. ano de 2003 aCAMPAGNA (2005) ref. ano de 2004 BAIO (2009) ref. ano de 2008 a ZAFFANI (2012) ref. ano de 2012

TRALBACK (2020) ref. ano de 2018

Fonte: Arquivo do autor

\section{6 - O córrego Santa Maria Madalena quanto a condutividade elétrica da} água

A condutividade elétrica da água do córrego Santa Maria Madalena variou de $4,5 \mu \mathrm{S} / \mathrm{cm}$. (valor mínimo (Ano de 2018) à $51 \mu \mathrm{S} / \mathrm{cm}$. (valor máximo (Ano de 2018), sendo que a média geral registrada de condutividade elétrica da água foi de $25 \mu \mathrm{S} / \mathrm{cm}$. Pelos dados aferidos pelos pesquisadores, é possível afirmar de acordo com os parâmetros estabelecidos dentro dos padrões de qualidade da água (Apêndice $\mathrm{E}$ - Significado Ambiental e Sanitário das Variáveis de Qualidade das Águas e dos Sedimentos e Metodologia Analíticas e de Amostragem - CETESB), que os valores de condutividade elétrica da água do córrego Santa Maria Madalena, estão dentro do aceitável. Portanto, o córrego Santa Maria Madalena, pela meta análise e pela análise realizadas durante o período histórico estudado, se encontra dentro da normalidade (valor abaixo de $100 \mu \mathrm{S} / \mathrm{cm}$ - Índice de referência Padrão CETESB) quanto os valores de condutividade elétrica da água, indicando uma água limpa (sem poluição). 
A Figura 24, à seguir referenciada, demonstra um Gráfico com os valores referentes a média e o desvio padrão, tanto da meta análise realizada (trabalhos realizados por pesquisadores anteriores, CAMPAGNA (2005) e BAIO (2009), quanto em relação a atual análise realizada, feito pelo corrente pesquisador TRALBACK (2020), em relação aos valores de condutividade elétrica da água do córrego Santa Maria Madalena.

Figura 24

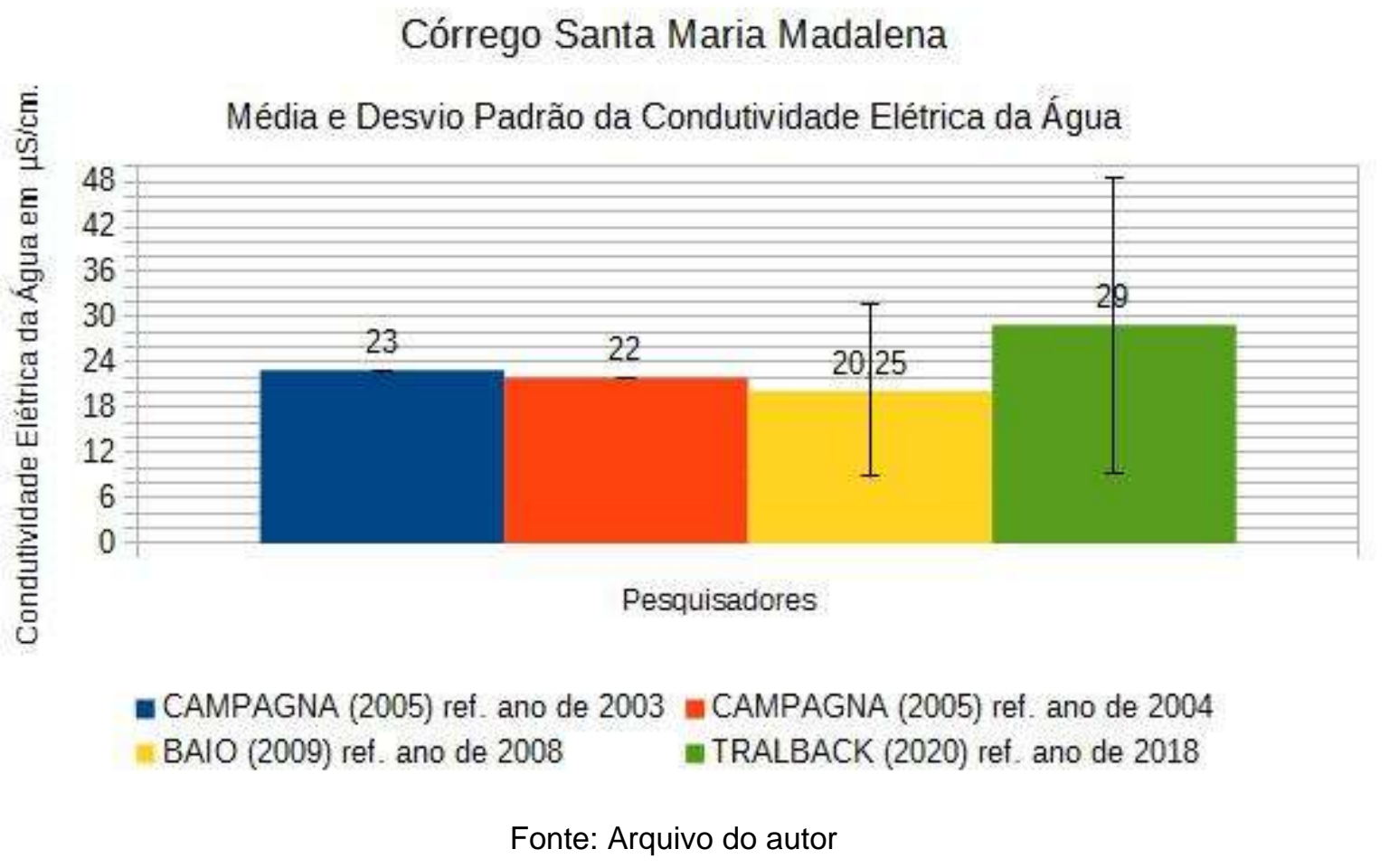

\section{7 - 0 córrego do Mineirinho quanto ao pH da água}

$\mathrm{O} \mathrm{pH}$ da água do córrego do Mineirinho variou de 6,3 (valor mínimo (Ano de 2018) à 7,04 (valor máximo (Ano de 2003), sendo que a média geral registrada de $\mathrm{pH}$ foi de 6,72. Pelos dados aferidos pelos pesquisadores, é possível afirmar de acordo com os parâmetros estabelecidos para a qualidade da água (Apêndice E - Significado Ambiental e Sanitário das Variáveis de Qualidade das Águas e dos Sedimentos e Metodologia Analíticas e de Amostragem - CETESB), que os valores estão dentro do aceitável para manutenção da biota em corpos d'água ( $\mathrm{pH}$ de 6 à 9). Portanto, o córrego do Mineirinho, pela meta análise e pela análise realizadas durante o período 
histórico estudado, se encontra dentro da normalidade quanto os valores de $\mathrm{pH}$, porém, atualmente, suas águas se encontram um pouco mais ácidas, com pH de 6,3 (2018).

A Figura 25, à seguir referenciada, demonstra um Gráfico com os valores referentes a média e o desvio padrão, tanto da meta análise realizada (trabalhos realizados por pesquisadores anteriores, CAMPAGNA (2005), quanto em relação a atual análise realizada, feito pelo corrente pesquisador TRALBACK (2020), em relação aos valores de $\mathrm{pH}$ (potencial Hidrogeniônico) da água do córrego do Mineirinho.

Figura 25

\section{Córrego do Mineirinho}

Média e Desvio Padrão referente ao $\mathrm{pH}$ da Água

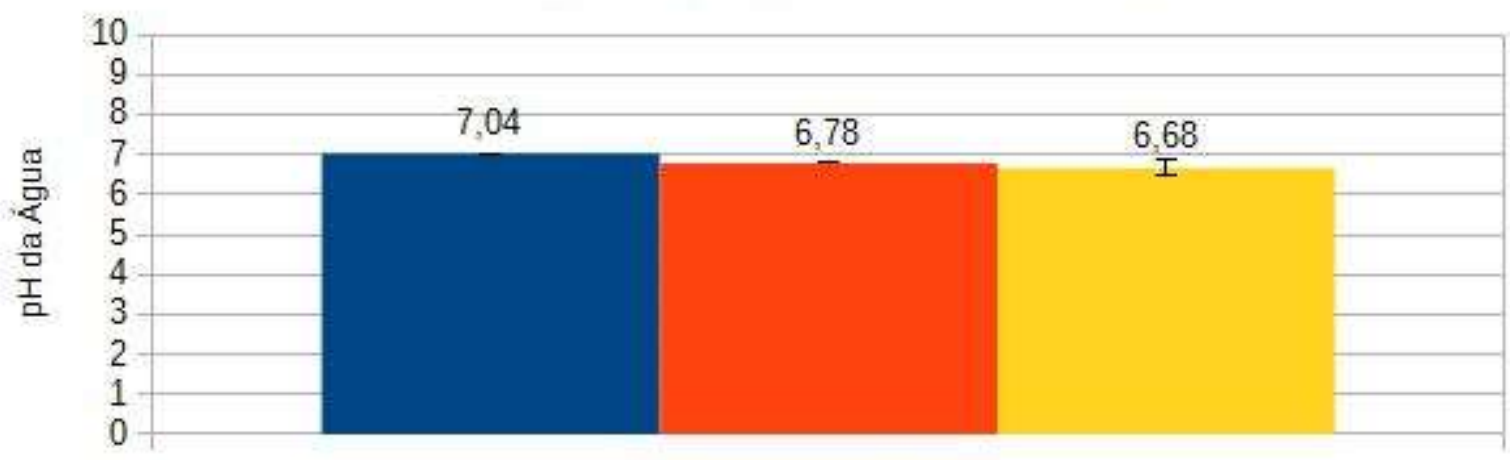

Pesquisadores

-CAMPAGNA (2005) ref. ano de $2003=$ CAMPAGNA (2005) ref. ano de 2004 TRALBACK (2020) ref. ano de 2018

Fonte: Arquivo do autor 


\section{8 - O córrego do Mineirinho quanto a temperatura da água}

A temperatura da água do córrego do Mineirinho variou de 19,7 ํㅡ (valor mínimo (Ano de 2003) à $25^{\circ} \mathrm{C}$ (valor máximo (Ano de 2018), sendo que a média geral registrada de temperatura foi de $23,2 \stackrel{\circ}{\circ}$. Pelos dados aferidos pelos pesquisadores, é possível afirmar de acordo com os parâmetros estabelecidos dentro dos padrões de qualidade da água (Apêndice E - Significado Ambiental e Sanitário das Variáveis de Qualidade das Águas e dos Sedimentos e Metodologia Analíticas e de Amostragem CETESB), que os valores de temperatura da água do córrego do Mineirinho, estão dentro do aceitável para manutenção da biota em corpos d'água. Portanto, o córrego do Mineirinho, pela meta análise e pela análise realizadas durante o período histórico estudado, se encontra dentro da normalidade quanto os valores de temperatura da água.

A Figura 26, à seguir referenciada, demonstra um Gráfico com os valores referentes a média e o desvio padrão, tanto da meta análise realizada (trabalhos realizados por pesquisadores anteriores, CAMPAGNA (2005) e ZAFFANI (2012), quanto em relação a atual análise realizada, feito pelo corrente pesquisador TRALBACK (2020), em relação aos valores de temperatura da água do córrego do Mineirinho. 
Figura 26

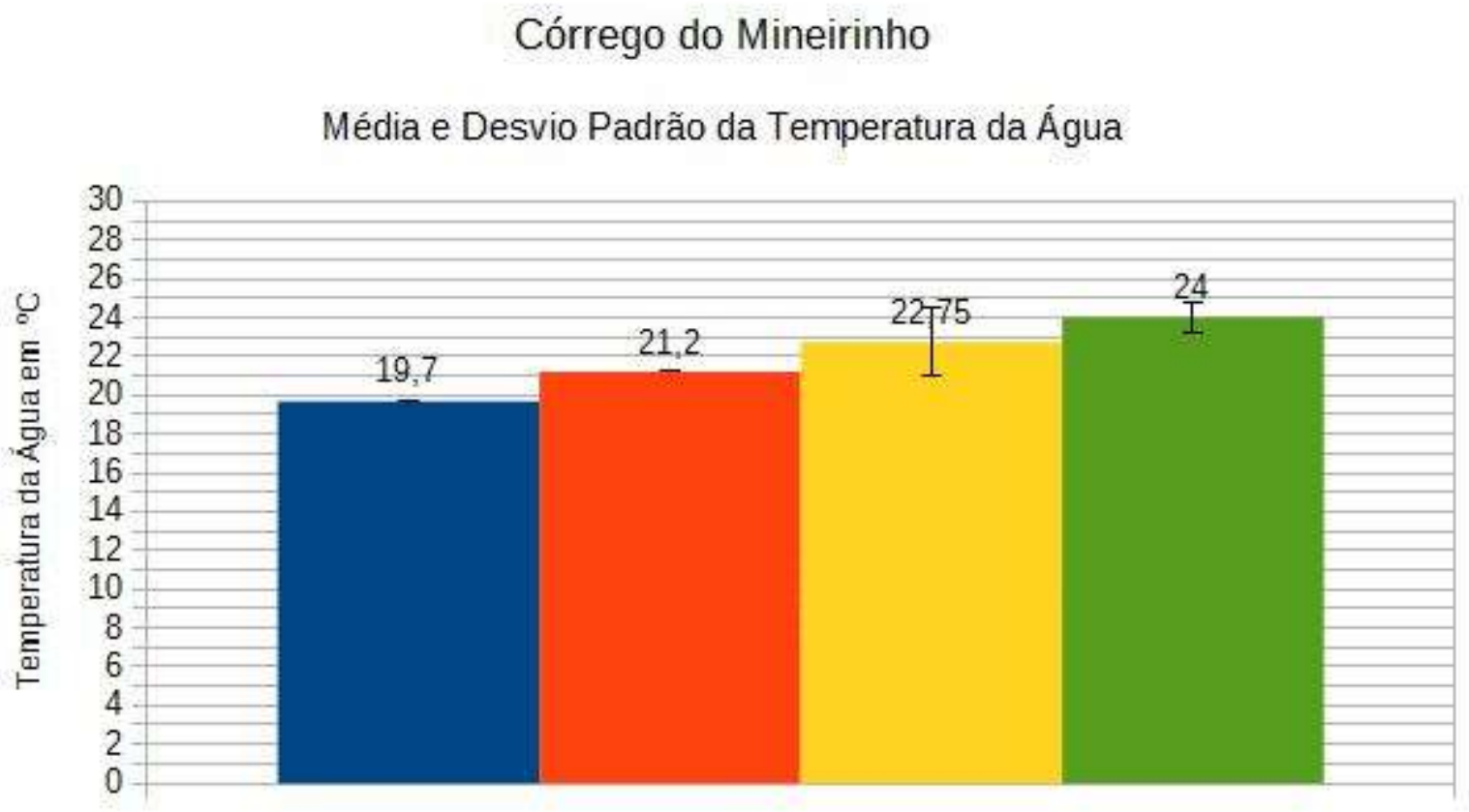

Pesquisadores

CAMPAGNA (2005) ref. ano de 2003 m CAMPAGNA (2005) ref. ano de 2004

ZAFFANI (2012) ref. ano de 2012 = TRALBACK (2020) ref. ano de 2018

Fonte: Arquivo do autor

\section{9 - 0 córrego do Mineirinho quanto a condutividade elétrica da água}

A condutividade elétrica da água do córrego do Mineirinho variou de $18 \mu \mathrm{S} / \mathrm{cm}$. (valor mínimo (Ano de 2018) à $121 \mu \mathrm{S} / \mathrm{cm}$. (valor máximo (Ano de 2018), sendo que a média geral registrada de condutividade elétrica da água foi de 52,90 $\mu \mathrm{S} / \mathrm{cm}$. Pelos dados aferidos pelos pesquisadores, é possível afirmar de acordo com os parâmetros estabelecidos dentro dos padrões de qualidade da água (Apêndice E - Significado Ambiental e Sanitário das Variáveis de Qualidade das Águas e dos Sedimentos e Metodologia Analíticas e de Amostragem - CETESB), que os valores de condutividade elétrica da água do córrego do Mineirinho, estão acima (121 $\mu \mathrm{S} / \mathrm{cm}$ (2018), ao valor limite aceitável (100 $\mu \mathrm{S} / \mathrm{cm}$ índice de referência Padrão - CETESB) indicando a poluição de suas águas. 
A Figura 27, à seguir referenciada, demonstra um Gráfico com os valores referentes a média e o desvio padrão, tanto da meta análise realizada (trabalhos realizados por pesquisadores anteriores, CAMPAGNA (2005)), quanto em relação a atual análise realizada, feito pelo corrente pesquisador TRALBACK (2020), em relação aos valores de condutividade elétrica da água do córrego do Mineirinho.

Figura 27

\section{Córrego do Mineirinho}

Média e Desvio Padrão referente a Condutividade Elétrica da Água

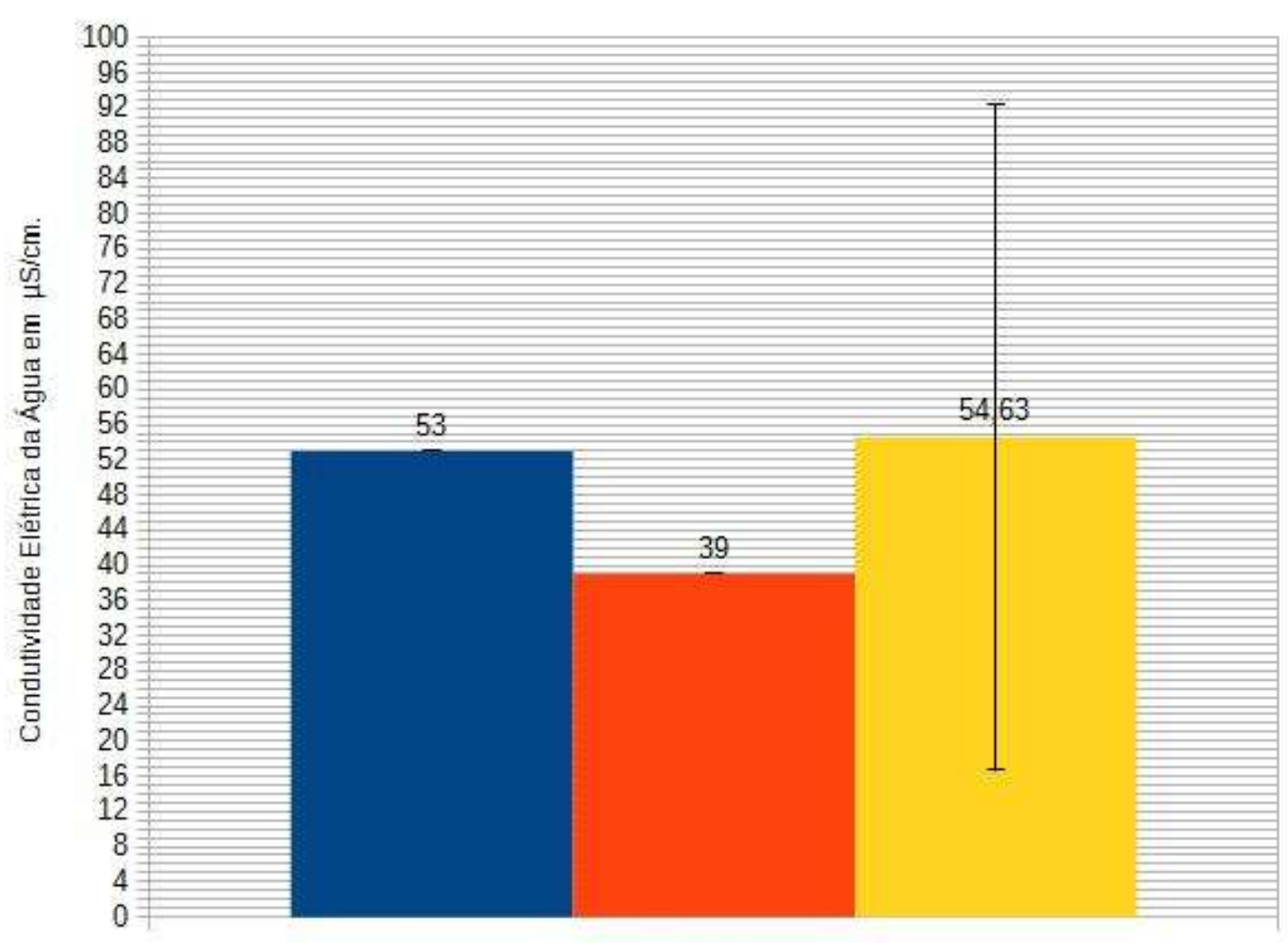

Pesquisadores

CAMPAGNA (2005) ref. ano de 2003 =CAMPAGNA (2005) ref. ano de 2004

TRALBACK (2020) ref. ano de 2018

Fonte: Arquivo do autor 


\section{8 - CONCLUSÃO}

A pesquisa visou realizar uma meta análise num período histórico de 30 anos, alguns córregos da cidade de São Carlos, dentre eles o córrego do Tijuco Preto, o córrego Santa Maria Madalena e o córrego do Mineirinho, no que se refere ao $\mathrm{pH}$ (potencial hidrogeniônico), temperatura e condutividade elétrica, bem como a confecção de uma cartilha de educação ambiental para ser utilizada pelos alunos das escolas de São Carlos.

A pesquisa cumpriu seus objetivos gerais e específicos, no que tange a meta análise dos dados que foram obtidos anteriormente pelos pesquisadores, bem como uma análise atual (pesquisa de campo), com a respectiva coleta de água, extração de dados, tabulação dos dados e a respectiva análise dos dados, para a verificação se a qualidade das águas de alguns córregos da cidade de São Carlos, melhoraram ou pioraram.

A pesquisa conclui que o córrego do Tijuco Preto, de acordo com o índice de referência Padrão - CETESB (Apêndice - Anexo), no que se refere aos valores de pH e temperatura se encontram dentro da normalidade, mas no que tange aos valores de condutividade elétrica, embora anteriormente estivesse mais poluído (índice de 467 $\mu$ S/cm BAIO (2009, p. 105 e 106) e essa poluição tenha diminuído, atualmente, ainda se encontra poluído $203 \mu \mathrm{S} / \mathrm{cm}$ (valor acima de $100 \mu \mathrm{S} / \mathrm{cm}$ conforme consta no Índice de referência Padrão CETESB para a qualidade da água doce.

Para o córrego Santa Maria Madalena, também de acordo com o índice de referência Padrão - CETESB (Apêndice - Anexo), foi possível verificar que os valores de $\mathrm{pH}$, temperatura e condutividade elétrica se encontram dentro da normalidade, apresentando uma excelente qualidade de água. Em relação ao córrego do Mineirinho que se encontra dentro das dependências da USP, Campus II, na cidade de São Carlos, no que se refere ao índice de referência Padrão - CETESB, foi possível verificar que, em relação ao $\mathrm{pH}$, apesar de suas águas se encontrarem dentro da normalidade (valor de 6-9 para mananciais de água doce), atualmente, suas águas se encontram um pouco mais ácidas, com pH de 6,3 (2018), tendo como referências pesquisas anteriores realizadas CAMPAGNA (2005, p.237). Quanto a temperatura do corpo 
d'água, a mesma se encontra dentro da normalidade, porém em relação a condutividade elétrica, houve uma piora em relação a meta análise realizada, pois foi verificado o aumento na poluição deste córrego, apresentando o valor de $121 \mu \mathrm{S} / \mathrm{cm}$ (valor acima de $100 \mu \mathrm{S} / \mathrm{cm}$, que é o Índice de referência Padrão CETESB para a qualidade da água), valor obtido, muito acima dos valores anteriormente coletados pela outra pesquisadora, CAMPAGNA (2005, p.237)..

Por fim, o presente estudo cumpriu também seu objetivo ao produzir e concluir uma cartilha de educação ambiental (apêndice - anexo) destinada ao complemento no ensino dos alunos das escolas de São Carlos. 


\section{9 - REFERÊNCIAS BIBLIOGRÁFICAS:}

ALVAREZ, Richard Paul Pehovaz. Estudo experimental e teórico da qualidade de água da drenagem urbana com base ecohidrológica. Dissertação de Mestrado. São Carlos: USP, 2010.

ALVES, F. Ministério do meio ambiente quer garantias na recuperação de áreas. Saneamento Ambiental, 48, p. 14-19, 1997.

ANA, Agência Nacional de Águas. Monitoramento da qualidade da água em rios e reservatórios. Brasília: ANA, 2019, 169 p.. Disponível em <https://capacitacao.ana.gov.br/conhecerh/handle/ana/76>, acesso em 03 de março de 2019.

ANELLI, Renato Luiz Sobral. Sistema viário e recuperação de recursos hídricos (córregos e nascentes) em São Carlos/SP. Artigo Científico. Rio de Janeiro: I Seminário Nacional sobre Regeneração Ambiental de Cidades - Águas Urbanas, realizado na Universidade Federal do Rio de Janeiro e publicado apenas nos anais do evento, 2005.

BAIO, José Augusto Fragale. Avaliação da contaminação nos principais corpos d’água do município de São Carlos/SP. Dissertação de Mestrado. São Carlos: USP 2009.

BENINI, Rubens de Miranda; MEDIONDO, Eduardo Mário. Urbanização e impactos no ciclo hidrológico na bacia do Mineirinho. Artigo Científico. Floresta e Ambiente, 2015, disponível em <http://www.scielo.br/pdf/floram/v22n2/2179-8087-floram-22-2-211.pdf>, acesso em 18 dez. 2017. 
BENINI, Rubens de Miranda; MEDIONDO, Eduardo Mário; MARTIOLI, Cid; TONISSI, Fabiano Botta. Cenários ambientais visando a mitigação de enchentes decorrentes da implantação do campus II-USP, São Carlos. Anais: XV Simpósio Brasileiro de Recursos Hídricos. Curitiba: 2003.

BRANCO, Samuel Murgel. Água origem uso e preservação. $2^{\underline{a}}$ ed. São Paulo: Moderna, 2010.

CAMPAGNA, Aline Fernanda. Toxidade dos sedimentos da bacia hidrográfica do rio Monjolinho (São Carlos-SP). Dissertação de Mestrado. Pirassununga: USP, 2005.

CAPPELINI, Luciana Teresa Dias. Análise dos pesticidas ametrina, atrazina, diuron, fipronil em amostras de água do Ribeirão do Feijão - São Carlos - SP. Dissertação de Mestrado. São Carlos: USP, 2008.

CORBI, J.J.; SAMPAIO, E.V.; DE RIBEIRO, V.R.; DOMINGOS, M.D.; FERRAZ FREIRE, C.; FERREIRA, P.S.; PELAEZ RODRÍGUEZ, M.; ROJAS, N.T.; STRIXINO, S.T. Levantamento preliminar da entomofauna aquática do centro nacional de pesquisa de peixes tropicais (CEPTA), Bol. Téc. Cepta, v.13, 2000.

DERISIO, J. C. Introdução ao controle da poluição ambiental. $2^{\text {a }}$ ed.. São Paulo: Editora Signus, 2000, 164 p..

DI BERNARDO, L.; DANTAS, A. Métodos e técnicas de tratamento de água. Vol. 1, 2aㅡ. Ed. São Carlos: RiMa, 2005, 792, p.

DOBSON, C.; BECK, G. G.. Watersheds: a practical handbook for healthy water. Canada: Frienses, Altona, Manitoba, 1999.

EID, Fabiana Badra; MOIÓLI, Julia; CORRÊA, Maria Sylvia. Como cuidar da nossa água. Coleção Entenda e Aprenda, 2ª Ed. São Paulo: BEÎ, 2004. 
ESTEVES, Francisco de Assis (coordenador).Fundamentos de Limnologia. 3를. (livro). Rio de Janeiro: Editora Interciência, 2011, 790 p...

FELICIDADE, Norma; MARTINS, Rodrigo Constante; LEME, Alessandro André. Uso e gestão dos recursos hídricos no Brasil: velhos e novos desafios para a cidadania. São Carlos: RiMA, 2003, 238 p..

FERREIRA, Marciel José; FERREIRA, Wendy Carniello; BOTELHO, Soraya AIvarenga. Avaliação da regeneração natural do entorno de uma nascente como estratégia para sua recuperação. Nota Científica. Porto Alegre: Revista Brasileira de Biociências. v. 5. Supl.1., p.573-575, 2007.

FERREIRA, Camila dos Santos; CUNHA-SANTINO, Marcela Bianchessi. Monitoramento da qualidade da água do rio monjolinho: a limnologia como uma ferramenta para a gestão ambiental. Artigo Científico. REA - Revista de Estudos Ambientais (online), 2014, V. 16, n.1, p. 27-37.

GARDEL, Marlene; OLIVEIRA, Maurício Pietrocola Pinto de; CASTELLAR, Sonia Maria Vanzela. Água hoje e sempre: consumo sustentável. São Paulo, Secretaria da Educação, Coordenadoria de Estudos e Normas Pedagógicas, 2004, 256 p..

GASTALDINI, M. C. C.; MENDONÇA, A. S. F. Conceitos para a avaliação da qualidade da água. In: Paiva J.B.D., Paiva, E.M.C.D. (organizadores). Hidrologia aplicada à gestão de pequenas bacias hidrográficas. Porto Alegre: ABRH. 2001, 625 p..

GOLTERMAN, H. L. et al. "Methods for phisicaland chemical analysis of fresh waters". Oxford: Blackwell, 1978, 213 p. (IBP Handbook, 8).

GUERRESCHI, R. M \& MELÃO, M. G. G. Monitoramento biológico da bacia hidrográfica do rio monjolinho pelo uso de macroinvertebrados bentônicos. Artigo Científico, 1997, p. 61-76. 
JÚNIOR, Abílio Gonçalves; PANARELLI, Ana Maria; DONATTI, Ariane Coelho; BEATO, Carlos Eduardo; TAFARELLO, Denise; ROCHA, Gerôncio; GIACOMINI, lara Bueno; FERRAZ, IveCiola; BONDIOLI, Jefferson Guedes; PEREZ, Laura Stela Naliato; MORTARI, Leila Cristina; MARCONDES, Neusa; FRANCHI, Nilceia; IKEMOTO, Silvia Marie; ROCHA, Tiago de Carvalho Franca; COELHO, Virgínia Maria Tesone. Relatório da situação dos recursos hídricos do Estado de São Paulo: ano base 2007. São Paulo: Secretaria do Meio Ambiente; Coordenadoria de Recursos Hídricos., 2009.

JÚNIOR. Arlindo Philippi; PELICIONI, Maria Cecília Focesi. Educação Ambiental e Sustentabilidade. Coleção Ambiental. (Livro). São Paulo: Manole, 2005.

MACKERETH, F. J. H., et. al. "water analysis: some revised methods for limnologists”. Freshwat. Biol. Assoc. Scientific Publication n. 36., Kendal: Titus, Wilson \& Son. Ltda. 1978.

MAGOSSI, Luiz Roberto; BONACELLA, Paulo Henrique. Poluição das águas. São Paulo: Editora Moderna, 1996. 56p.

MARQUES, Tássia Rios urbanos, paisagens invisíveis. Disponível em <https://tassiamarques.wordpress.com/sitio/>, acesso em 18 dez. 2017.

MARTINS, Leandro Guimarães Bais. Determinação de parâmetros hidrológicos por técnicas de sensoriamento remoto em macrodrenagem urbana. Dissertação de Mestrado. São Carlos: USP, 2012.

MORAES, America Jacintha de. Manual para avaliação da qualidade da água-1. São Carlos: RiMa, 2001.

NEGREIROS, S. CETESB conclui inventário e prepara plano de ação, Saneamento Ambiental, n. 46, p. 30-34, 1997. 
NUNES, Maria Edna Tenório. Avaliação dos efeitos de agrotóxicos sobre a fauna edáfica por meio de ensaios ecotoxicológicos com Eiseniaandrei (Annelidaoligochaeta) e com comunidade natural de solo. Tese de Doutorado. São Carlos: USP, 2010.

OTTAWAY, James Henry. Bioquímica da poluição. Volume 29, Tradução de Luiz Pitonmbo e Sérgio Massaro, São Paulo: EDUSP - Editora da Universidade de São Paulo, 1982.

PALÁCIOS, Antônio Carlos; RODRIGUES, Flavia Braga; JUNIOR, Abílio Gonçalves. Guia do sistema paulista de recursos hídricos: comitês de bacias: $\mathrm{CRH}$, COFEHIDRO, CORHI/Secretaria do Meio Ambiente. São Paulo: SMA, 2008, 96 p..

PELATTI, Isabela. Impacto do desenvolvimento urbano da cidade de São Carlos (SP) sobre o rio Monjolinho e avaliação de sua condição desde as nascentes até a captação do Espraiado. Dissertação de Mestrado. São Carlos: USP, 2004.

PESQUISA DA POPULAÇÃO DE SÃO CARLOS, Fonte: <https://cidades.ibge.gov.br/xtras/perfil.php?lang=\&codmun=354890\&search=sao-paulo|sao-carlos>, acesso em 18 de dez. 2017.

PIVELI, Roque Passos; KATO, Mario Takayuki. Qualidade das águas e poluição: aspectos físico-químicos. São Paulo, ABES, 2006.

PLATE, E. .Auswirkung der urbanisierung au den wasserhaushalt. In: wasserwirtschaft, v.66, n.1/1, p-7-14, 1976.

PONTREMOLEZ, Nataska Schincariol. Estudo das inundações em cenários alternativos de uso e ocupação do solo na bacia hidrográfica do córrego do mineirinho em São Carlos. Dissertação de Mestrado. São Carlos, USP, 2013. 
PORTO-GONÇALVES, Carlos Walter, O desafio ambiental. 3ª Edição. Rio de Janeiro: Record, 2012.

PRIMACK, Richard. B.; RODRIGUES, Efrain. Biologia da conservação. Londrina: E. Rodrigues, 2001.

QUIRINO, Tarcízio Rego; IRIAS, Luiz José Maria; WRIGHT, James Terence Coulter. Impacto agroambiental: perspectivas, problemas, prioridades. $1^{\text {a }}$ Edição. São Paulo: Editora Edgard Blucher Ltda., 1999.

RODRIGUES, Ricardo Ribeiro; FILHO, Hermógenes de Freitas Leitão. Matas ciliares: conservação e recuperação. $2^{\mathrm{a}}$ Edição e $2^{\mathrm{a}}$ Reimpressão. São Paulo: Editora Universidade de São Paulo, Fapesp, 2009.

RODRIGUEZ, Marlon Peláez. Avaliação da qualidade da água da bacia do alto do jacaré-guaçu/sp (ribeirão do feijão e rio do monjolinho) através de variáveis físicas, químicas e biológicas. Tese de Doutorado. São Carlos: EESC/USP, 2001.

SANTOS, José Eduardo. Anais do VIII seminário regional de ecologia. Programa de pós-graduação em ecologia e recursos naturais. São Carlos: Universidade Federal de São Carlos, 1997.

SANTORO, Jair; AMARAL, Rosangela do; MONI, Sandra. Você sabe o que é erosão continental?. Número 3. Coleção Geonatural, 1를 Edição, (Cartilha). São Paulo: Instituto Geológico, 2015.

SANTOS, José Eduardo. Anais do VIII seminário regional de ecologia. Volume 1, (Livro).São Carlos: UFSCAR, 1997.

SAUVAIN, Philip. Rios e vales. Traduzido do Título Original "Rivers andvalleys" por Antivan Guimarães Mendes. São Paulo: Editora Scipione, 1998. 
SCHINAIDER, Jaison; KRAUSE, Décio “Indiscernibilidade e identidade em química: aspectos filosóficos e formais" Artigo Científico no "site" SCIELO - disponível em:< https://www.scielo.br/scielo.php?script=sci_arttext\&pid=S010060452014000100004 >, acesso em 22 de agosto de 2020 .

SOUZA, Amanda Baldochi. Avaliação da qualidade ambiental nas nascentes do rio monjolinho na porção à montante da estação de captação de água do espraiado, São Carlos, SP. Dissertação de Mestrado. São Carlos: UFSCAR, 2011.

TAUK-TORNISIELO, Sâmia Maria; GOBBI, Nivar; FOWLER, Harold Gordon. Análise ambiental: uma visão multidisciplinar. $2^{\mathrm{a}}$ Edição revisada e ampliada, São Paulo: Editora da UNESP, 1995.

TEIXEIRA, Cristianny Villela; SANTOS, Devanir Garcia dos; ENGEL, Diana Wahrendorff; HESSEN, Érica de Castro; CARVALHO, Flavio Herminio de, CARDOSO, Herbert Eugênio de Araujo; MAZZOLA, Marcelo; COSTA, Marcelo Pires da; LIBÂNIO, Paulo Augusto C.; GENERINO, Regina Coeli Montenegro; MELO, Vivyanne Graça de; PALANIAPPAN, Meena; GLEICK, Peter H.; ALLEN, Lucy; COHEN, Michael J.; CHRISTIAN-SMITH, Juliet; SMITH, Courtney. Cuidando das águas - soluções para melhorar a qualidade dos recursos hídricos. Agência Nacional de Águas; Programa das Nações Unidas para o Meio Ambiente. Brasília: ANA, 2011.

TEMÓTEO, Tássia Gaspar. Indicadores de Benchmarking dos serviços de saneamento voltados a populações vulneráveis. Dissertação de Mestrado. São Carlos: USP, 2012.

TONISSI, Rosa Maria Tóro; OLIVEIRA, Haydée Torres de. Percepção ambiental em relação à área verde da bacia hidrográfica do Córrego da Água Quente (São Carlos, SP) como subsídio para a educação ambiental. Artigo Científico. Rio 
Claro: VII EPEA - Encontro Pesquisa em educação Ambiental, realizado de 07 à 10 de julho de 2013.

TUNDISI, José Galizia. Água no século XXI: enfrentando a escassez. 2ª Ed. São Carlos: RiMa, 2005.

TUNDISI, José Galizia; MATSUMARA-TUNDISI, Takako, PARECHI, Daniela Cambeses; LUZIA, Anna Paula; HAELING, Paulo H. Von; FROLLINI, Eduardo H. A bacia hidrográfica do Tietê/Jacaré: estudo de caso em pesquisa e gerenciamento. Artigo Científico. Estudos Avançados 22 (63), 2008, p. 159-172.

TUCCI, Andréa; SANT'ANNA, Célia Leite; SILVA, Daniela; RIOS, Fernanda; LUNA, Luciano; GEMELGO, Marcina P.; AZEVEDP, Maria Teresa P.; GENTIL, Regina C.; HONDA, Ricardo Yukio; MELCHER, Silvia. Atlas de cianobactérias e microalgas de águas continentais brasileiras. São Paulo: Secretaria de Estado de Meio Ambiente de São Paulo - Instituto de Botânica, 2013.

TUCCI, Carlos Eduardo Morelli. Águas urbanas. Revista Estudos Avançados da USP, no 63, volume 22. São Paulo: USP,2008, p. 97-112, Disponível em:<http://www.revistas.usp.br/eav/article/view/10295>, acesso em 09 jan. 2018.

TUCCI, Carlos Eduardo Morelli. Hidrologia: ciência e aplicação.1a Edição, São Paulo: EDUSP - Editora Universidade de São Paulo, 1993.

TUCCI, Carlos Eduardo Morelli; NETTO, Oscar de Moraes Cordeiro. Prospecção tecnológica recursos hídricos. Brasília: Centro de Gestão e Estudos Estratégicos, CGEE, 2005, 100 p.

VIANA, Sabrina Mieko. Riqueza e distribuição de macrófitasaquáticas no rio monjolinho e tributários (São Carlos, SP) e análise de sua relação com as variáveis físicas e químicas. Dissertação de Mestrado. São Carlos: EESC/USP, 2005. 
Von Sperling, M. Introdução à qualidade das águas e ao tratamento de esgotos. 2ª Edição, Belo Horizonte: DESA UFMG, 1996. 243 p..

WALLACE, Bruce. O ambiente: como eu o vejo, a ciência não é suficiente. Tradução e Revisão, Prof. Dr. Francisco A. de Mouraduarte, José Tadeu de Sales e Alvehy Martins Banks Leite. Ribeirão Preto: FUNPEC, 2002.

YNOUE, Rita Yuri; REBOITA, Michelle S.; AMBRIZZI, Tércio; SILVA, Gyrlene A. M. da; BOIASKI, Nathalie T. Meteorologia. 1a Edição, São Paulo: USP, UNIVESP, Edusp, 2014 Licenciatura em Ciências, Módulo 2: O Ambiente da Terra.

ZAFFANI, Aline Gomes. Poluição difusa da drenagem urbana com base ecohidrológica: diagnóstico atual e cenários de longo prazo em bacias urbanas de São Carlos, SP. Dissertação de Mestrado. São Carlos: USP, 2012. 
10 - APÊNDICE 

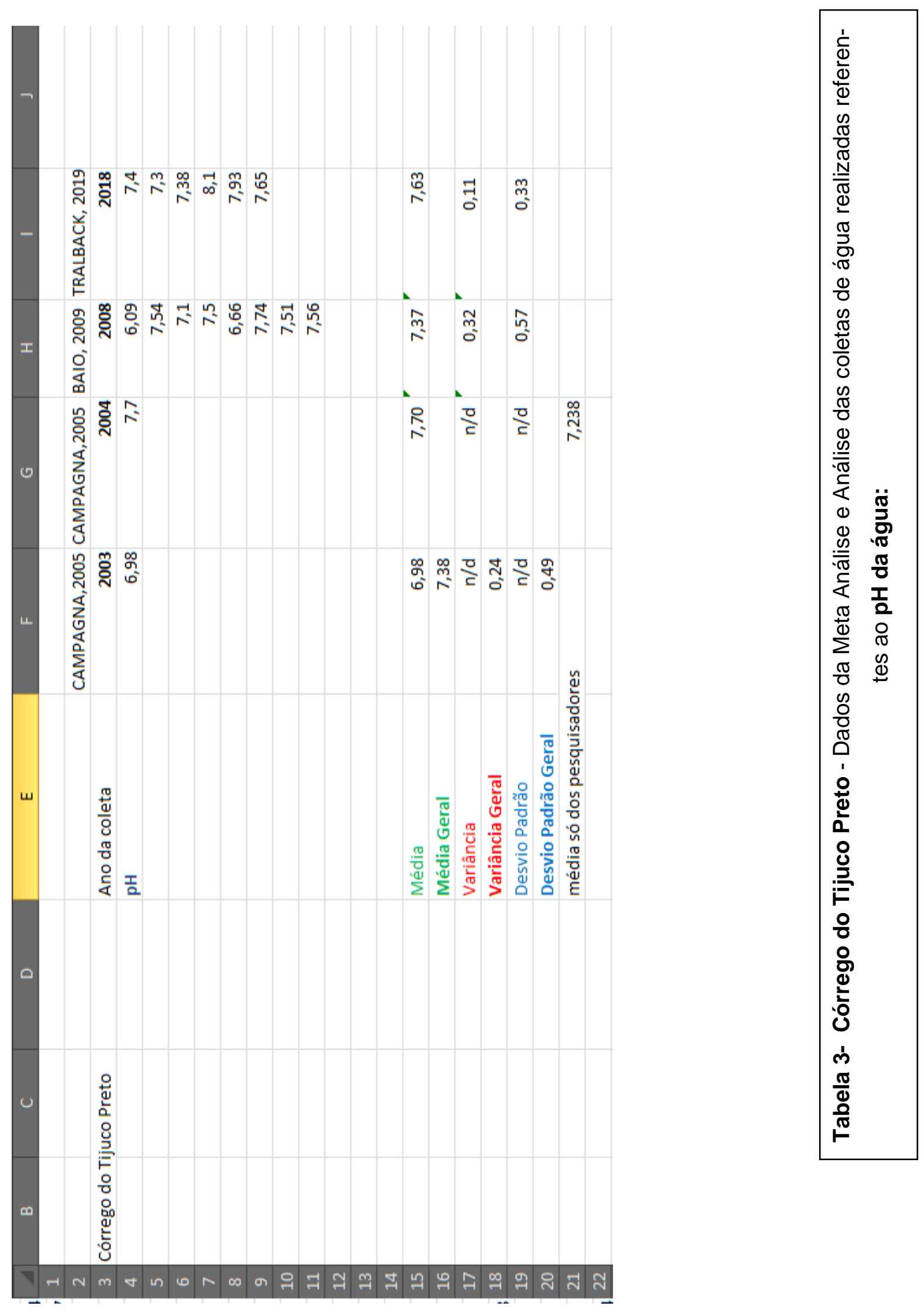


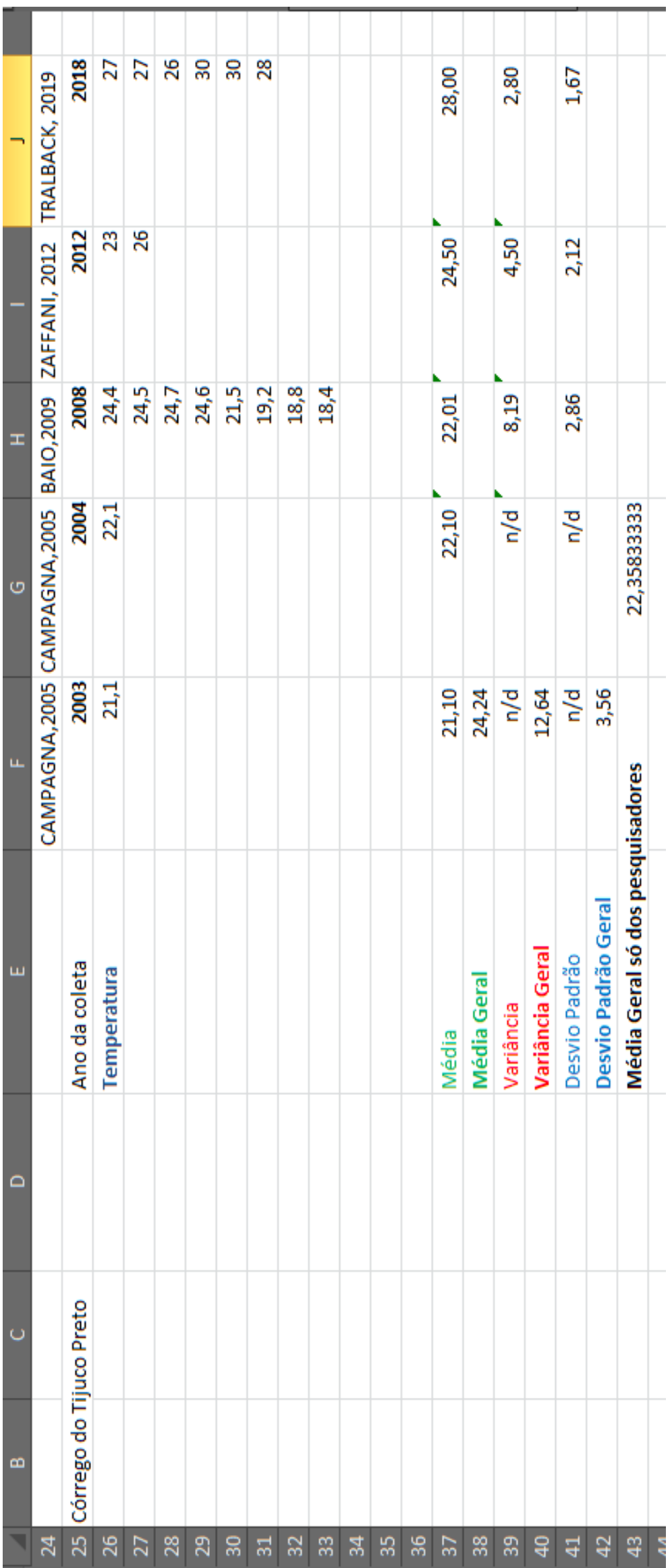

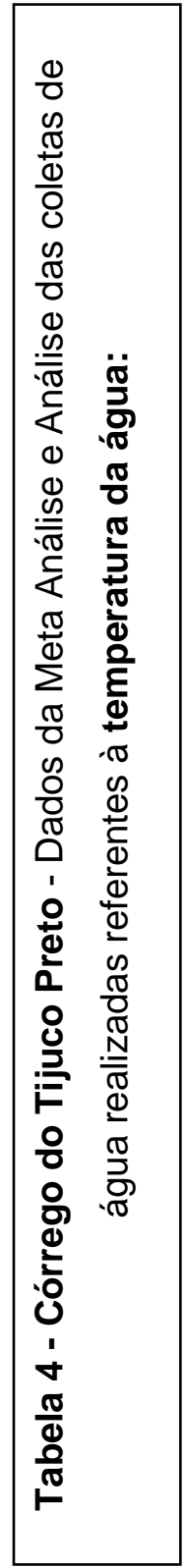



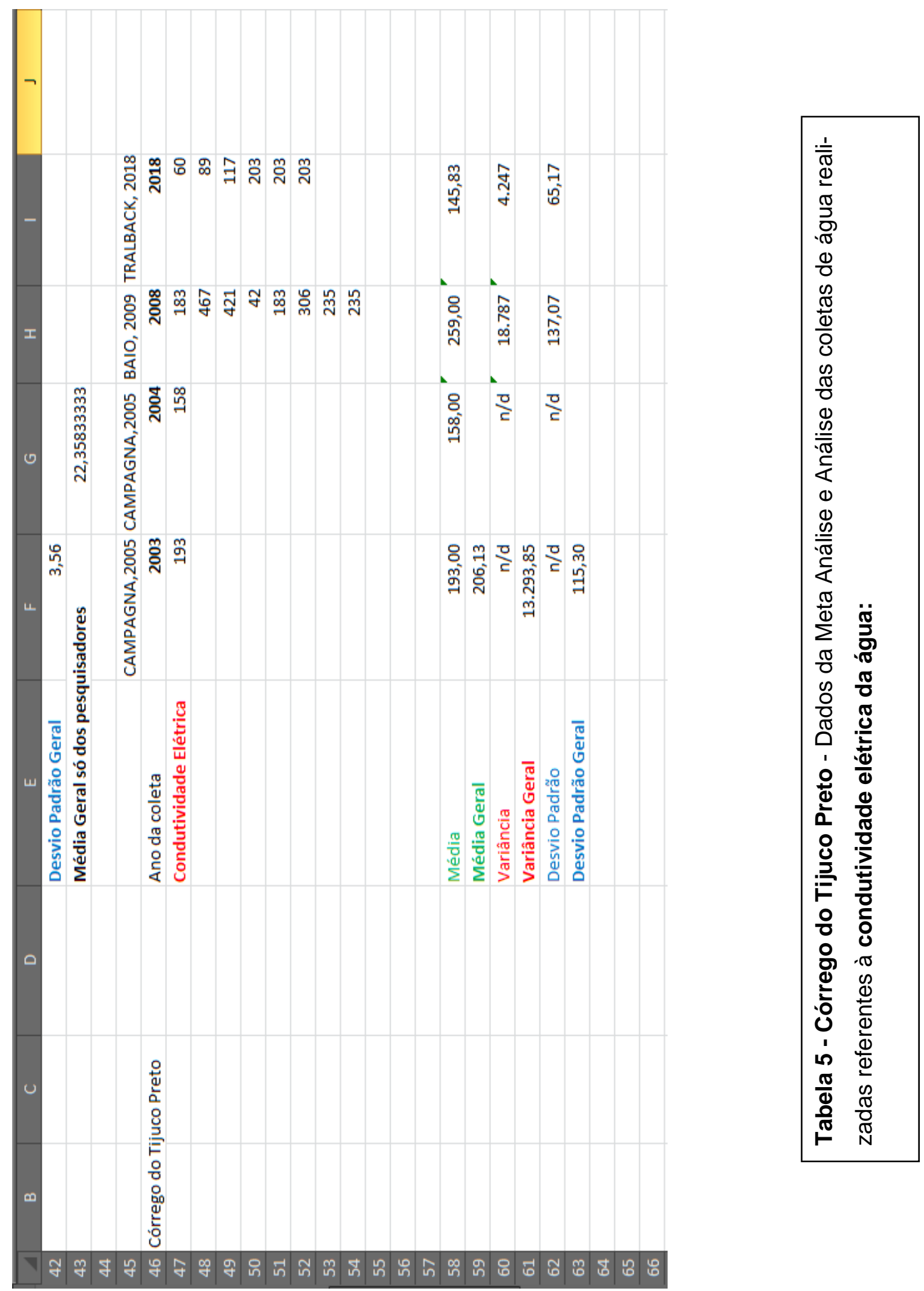

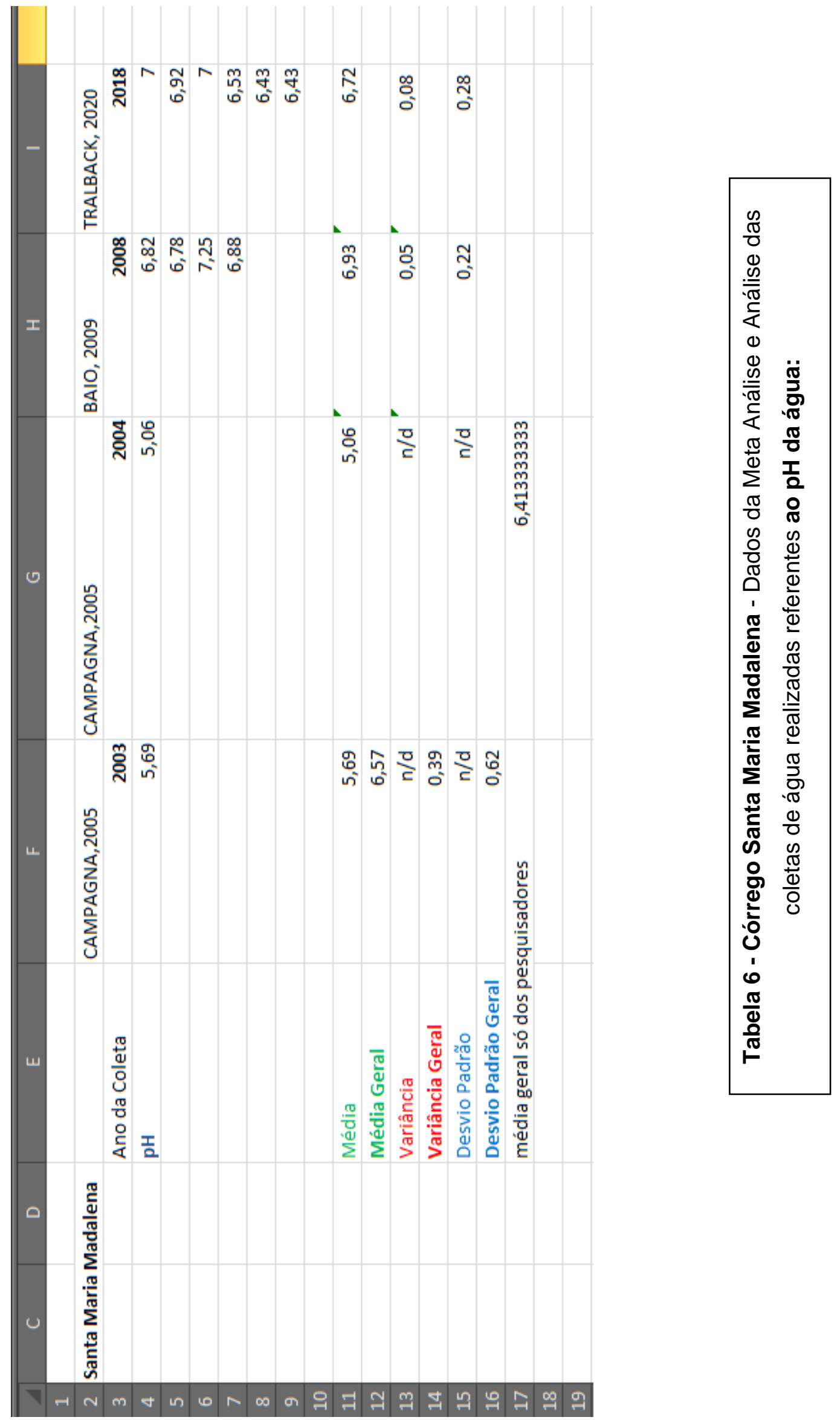


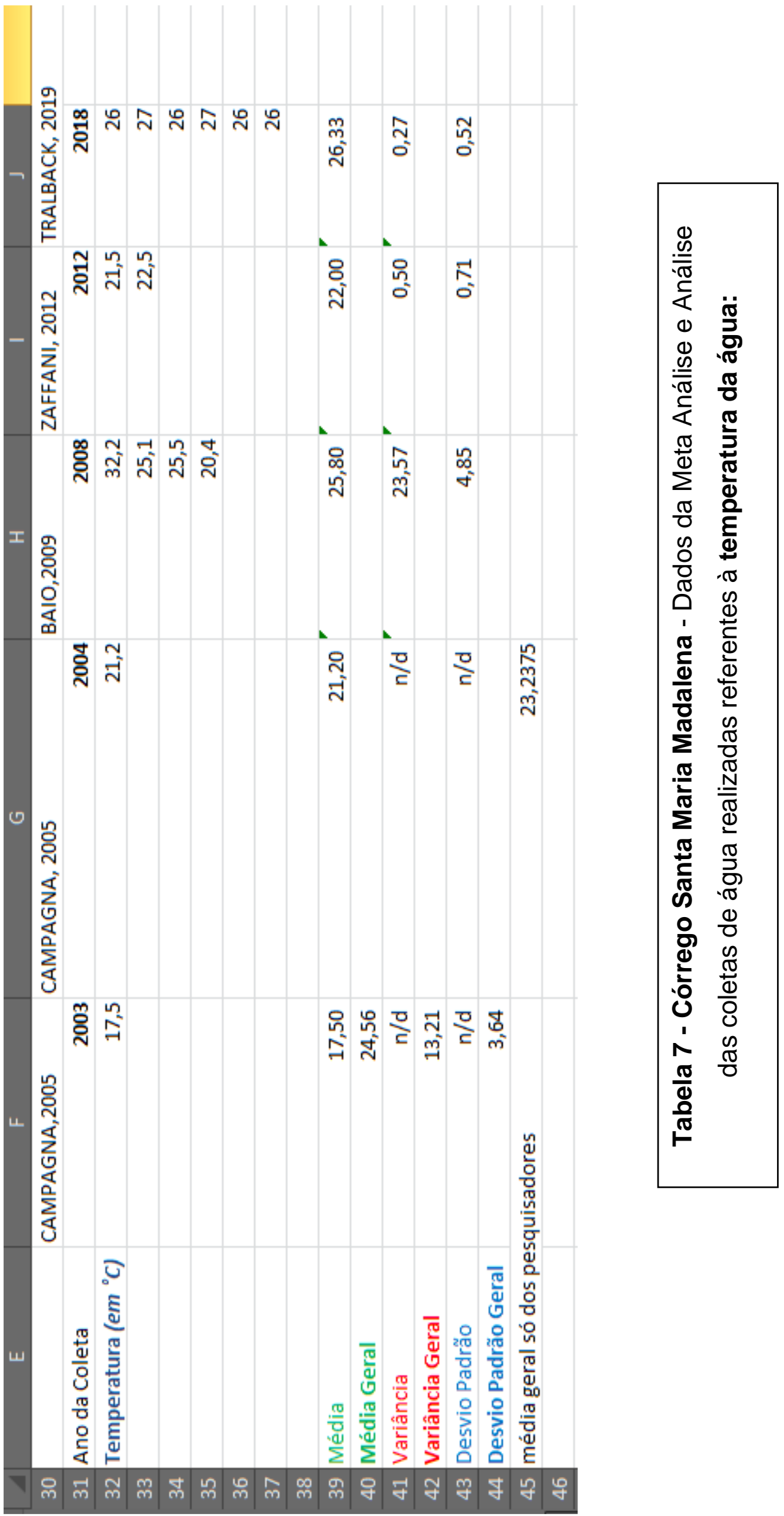



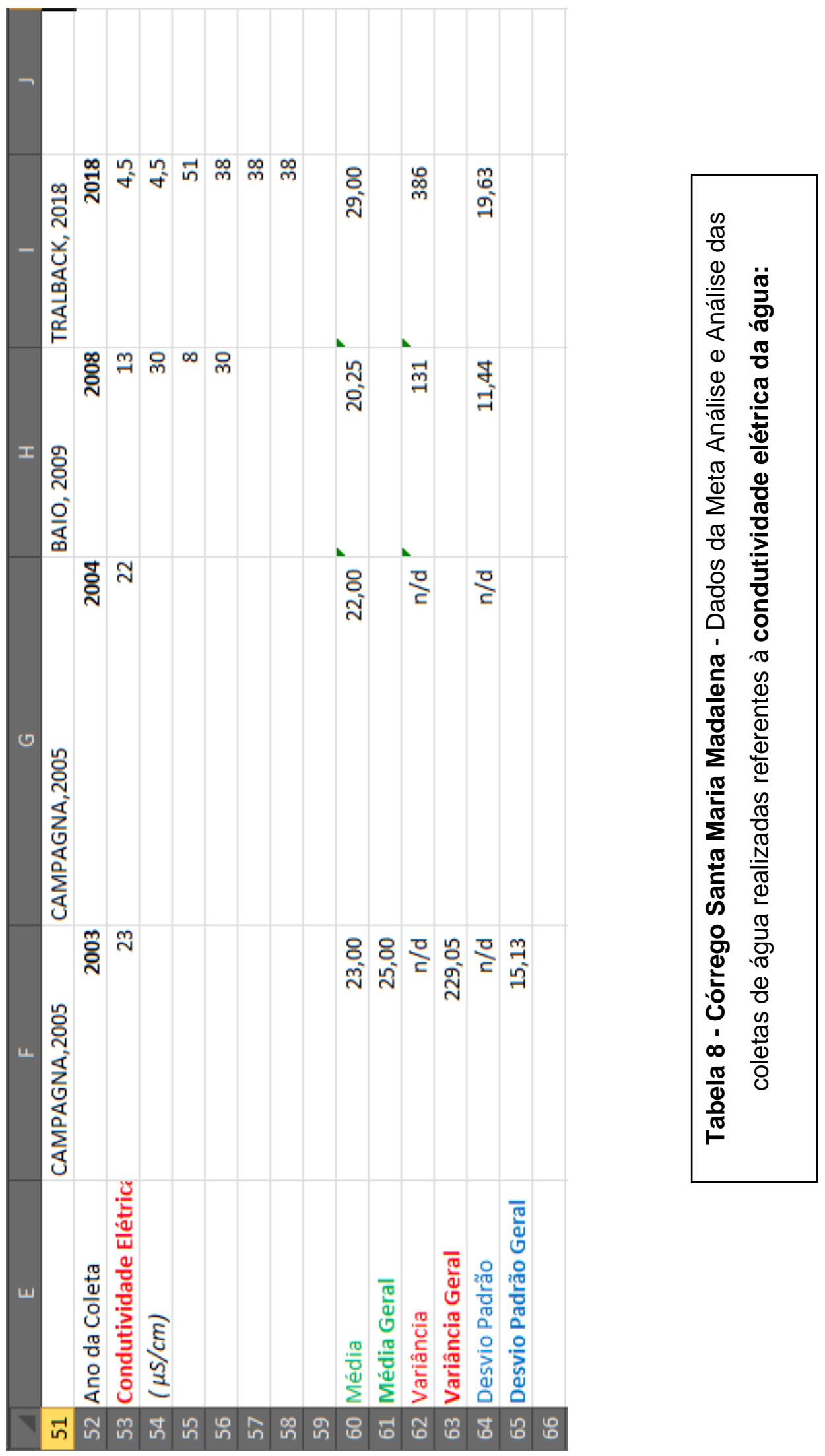


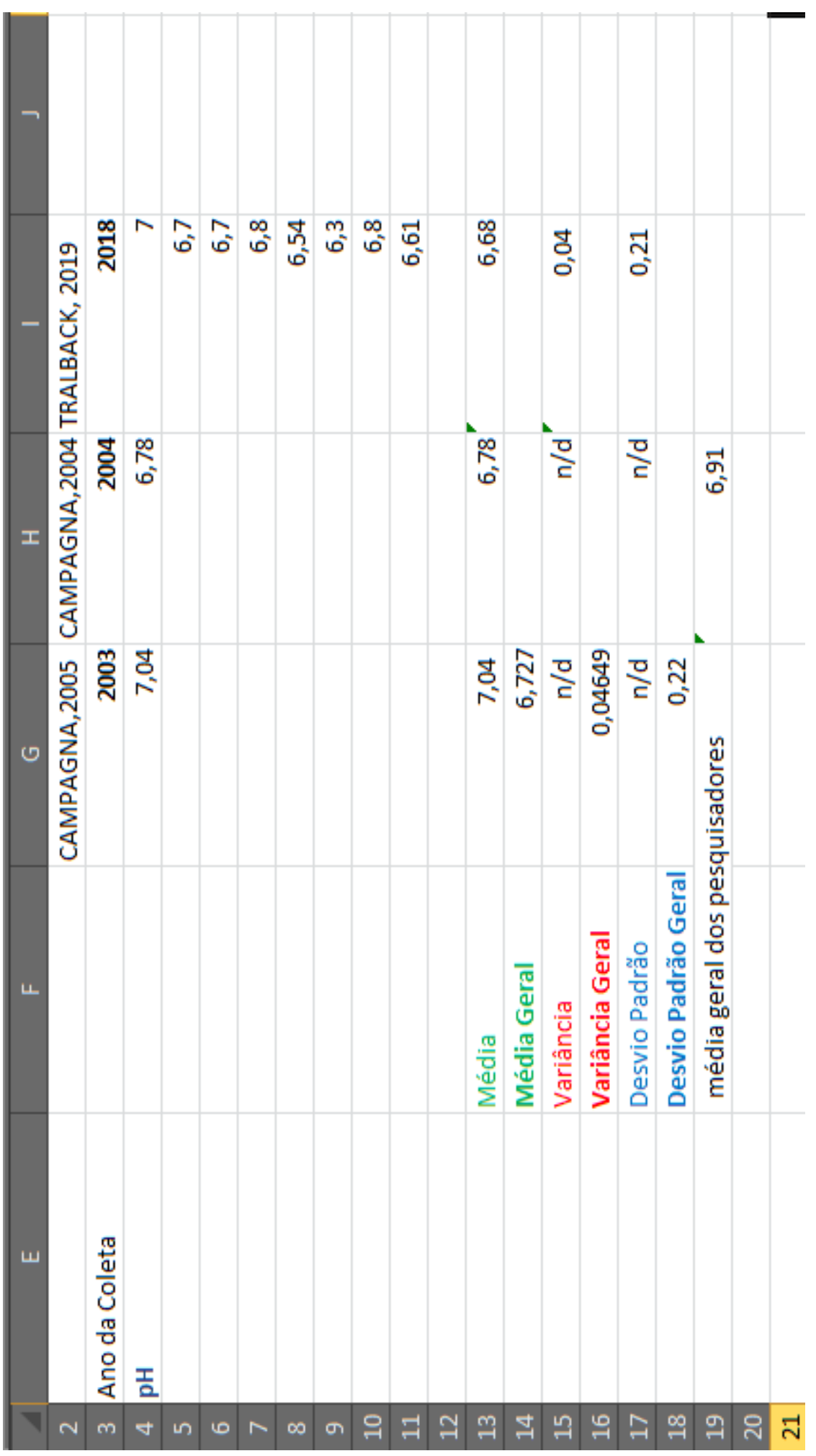

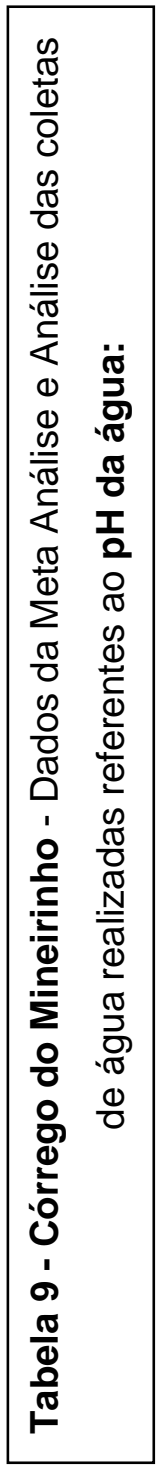



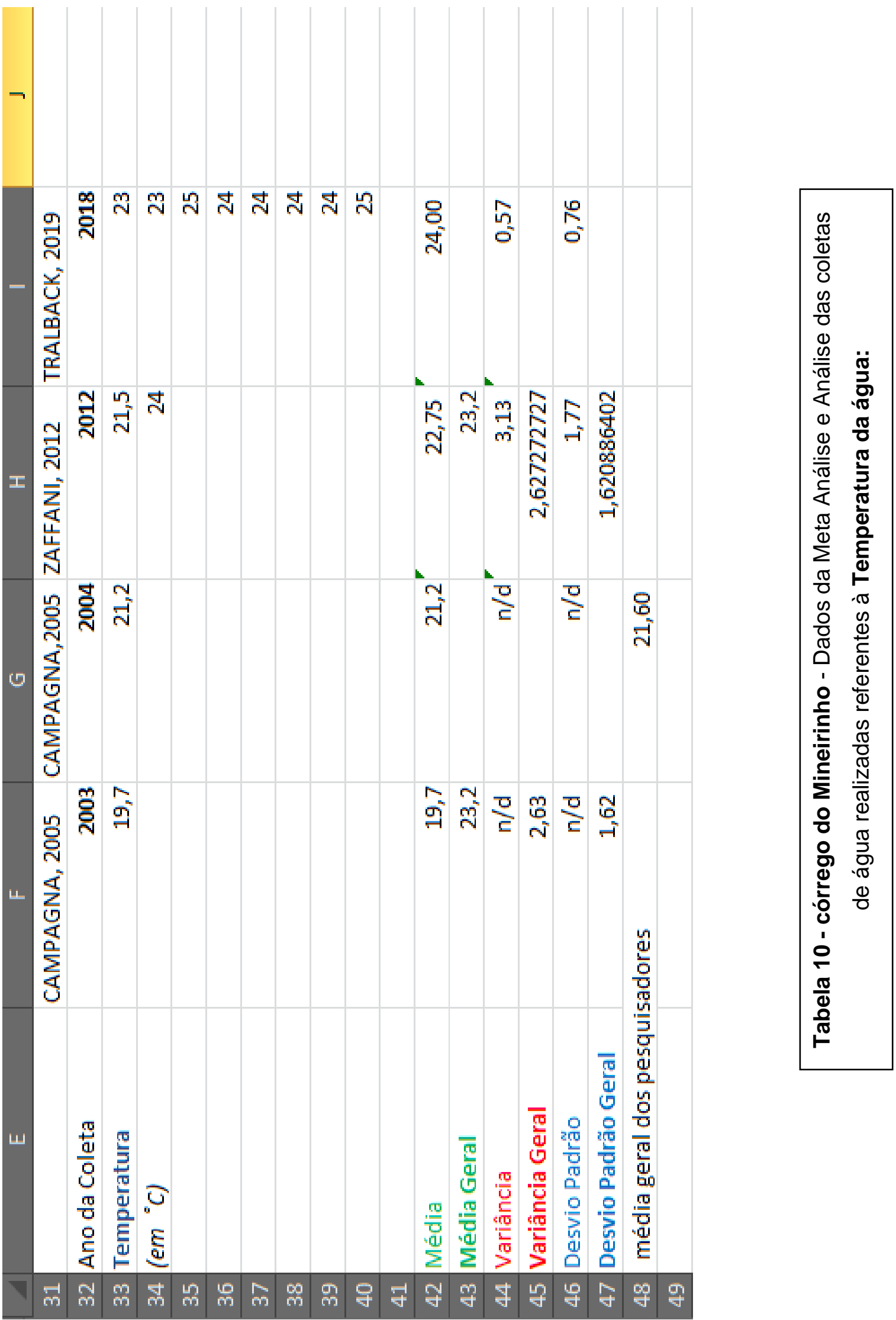


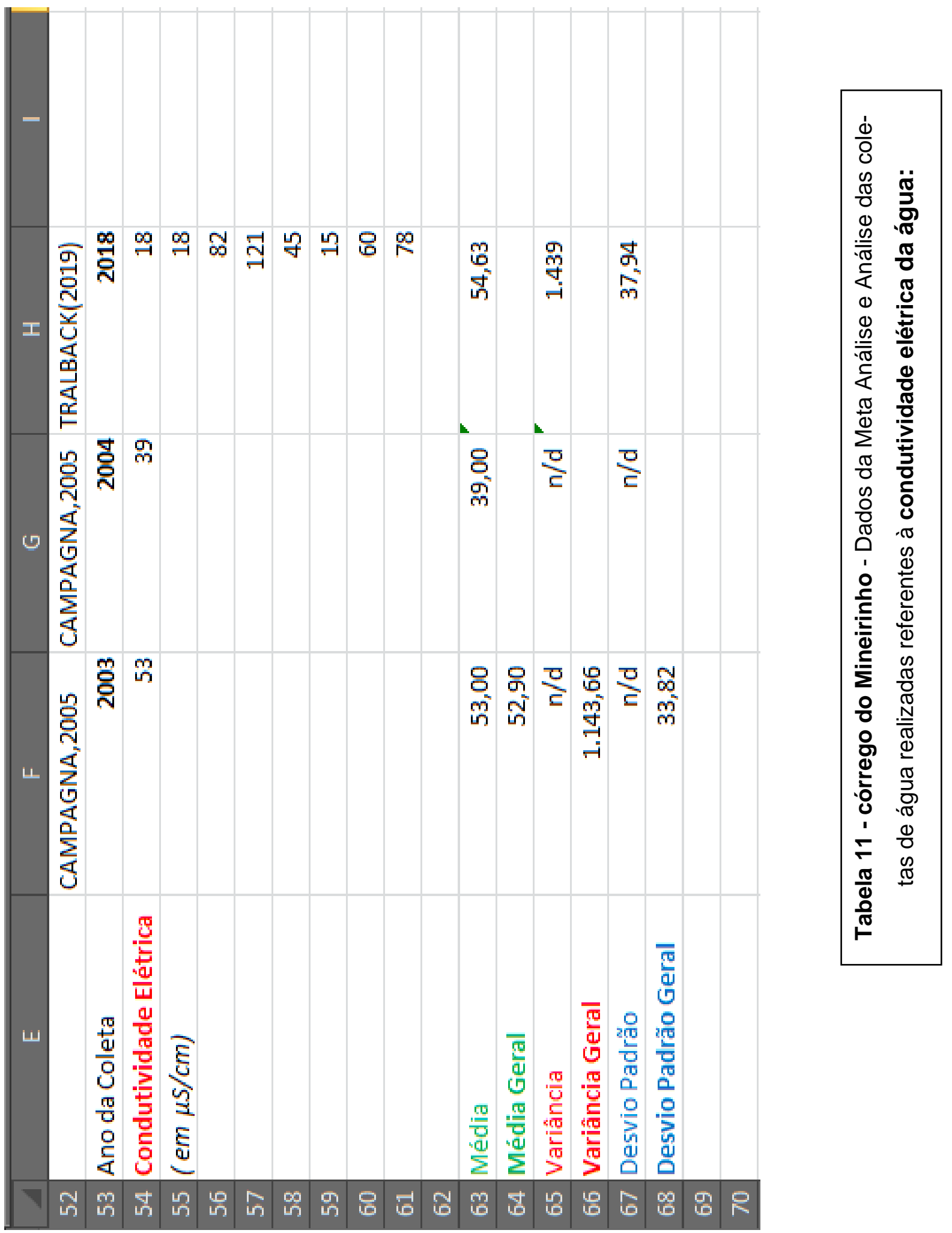




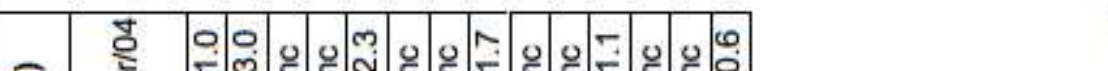

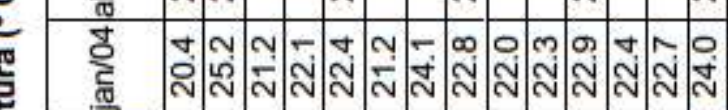

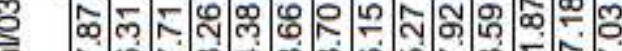

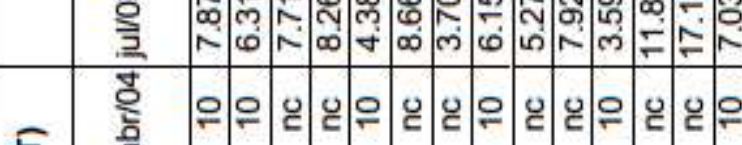

点

पे 0 म 00 ०

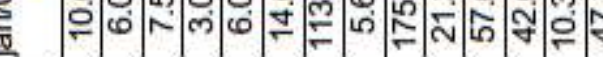

을

\section{용}

응

ํㅠำ 


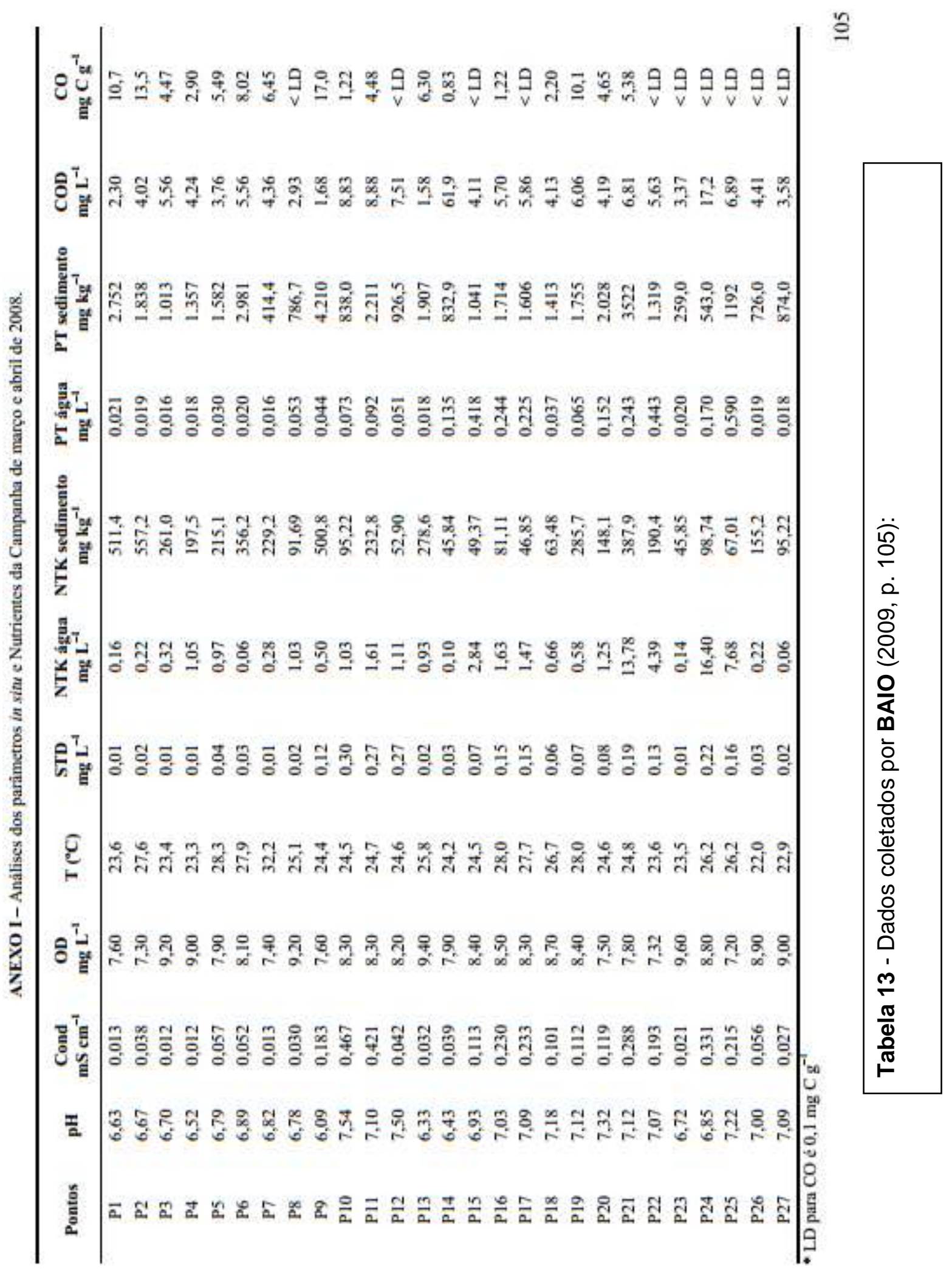




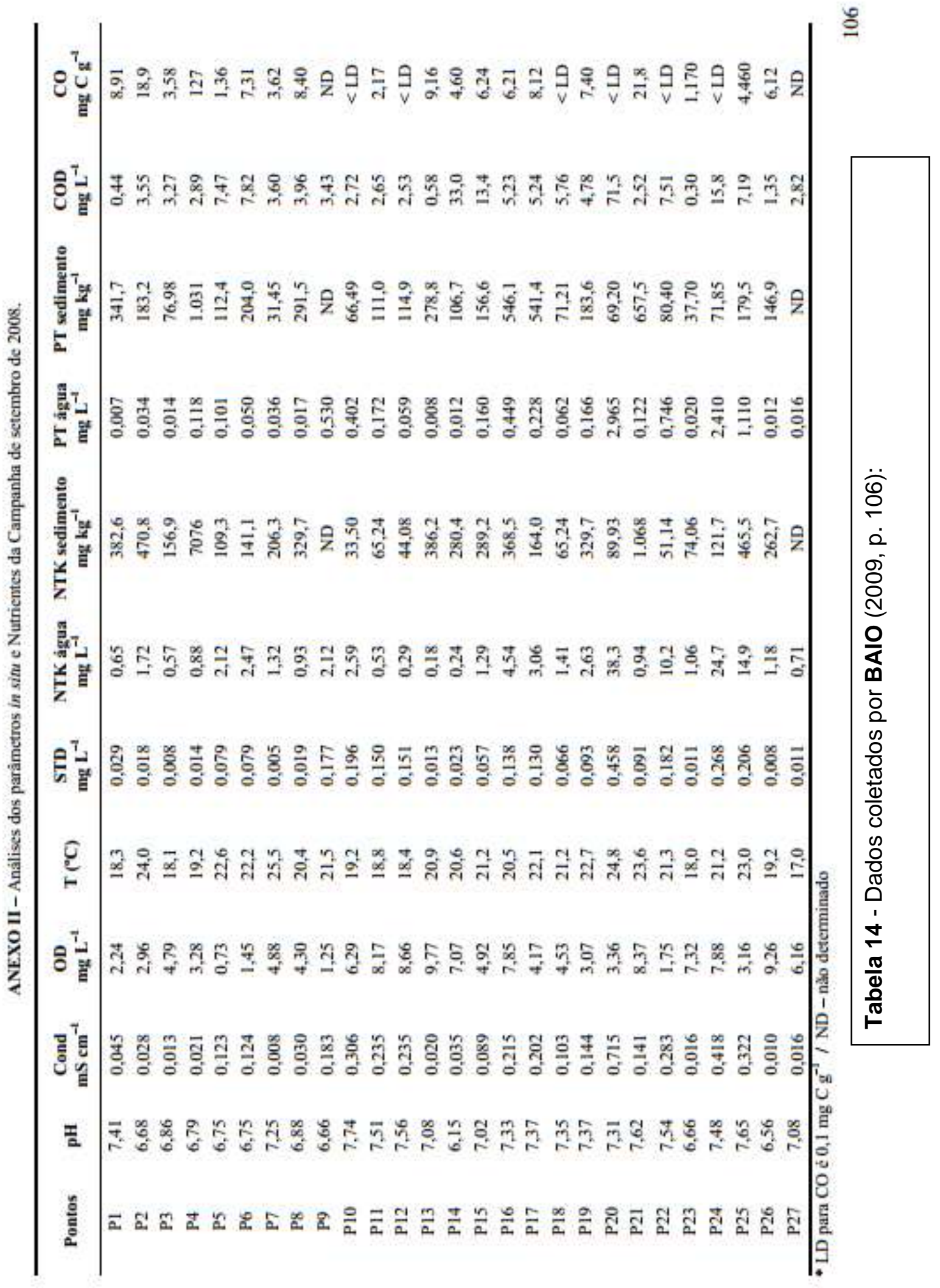


r

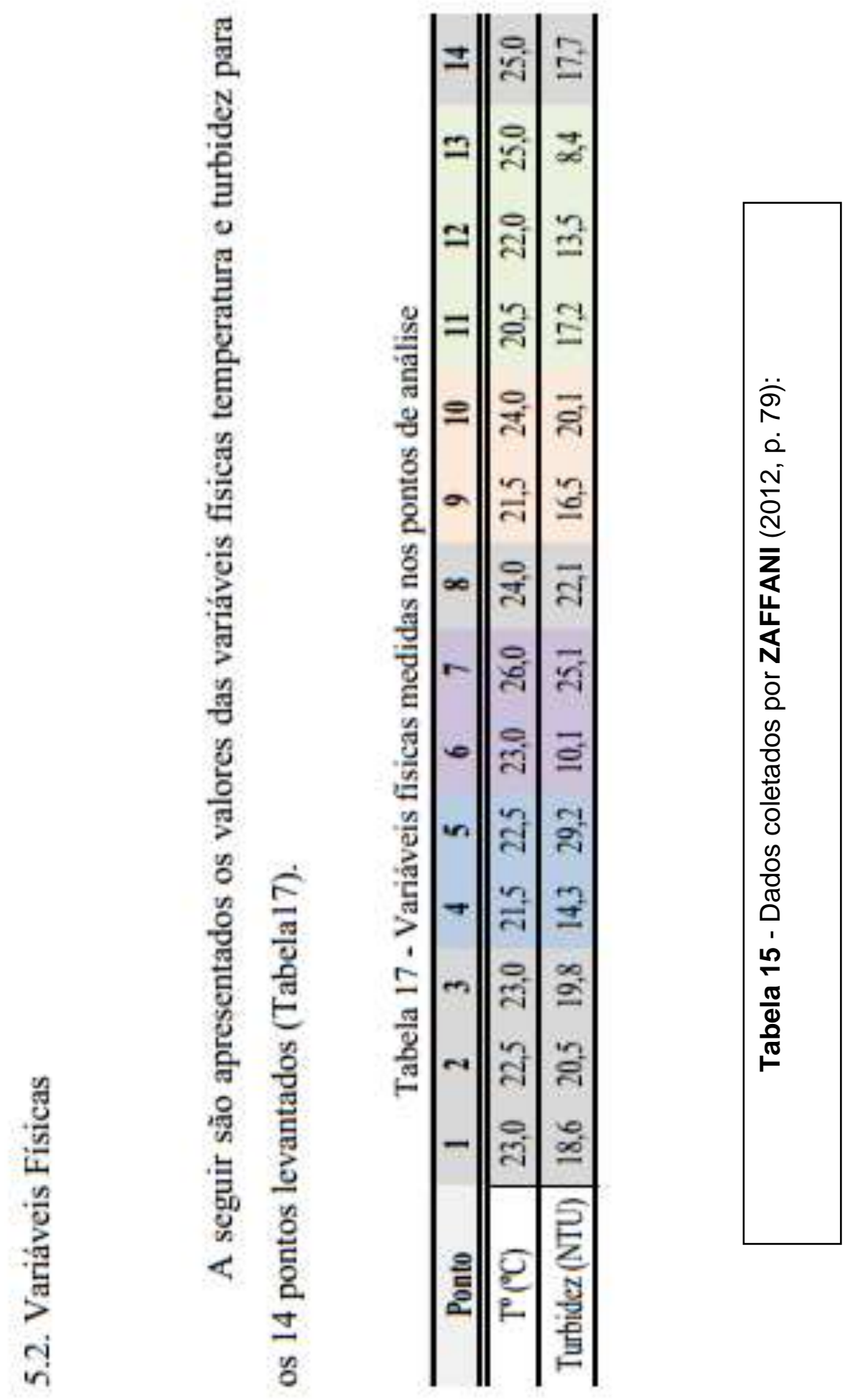


11 - PRODUTO FINAL: CARTILHA DE EDUCAÇÃO AMBIENTAL 
Cartilhade

Educação Ambiental

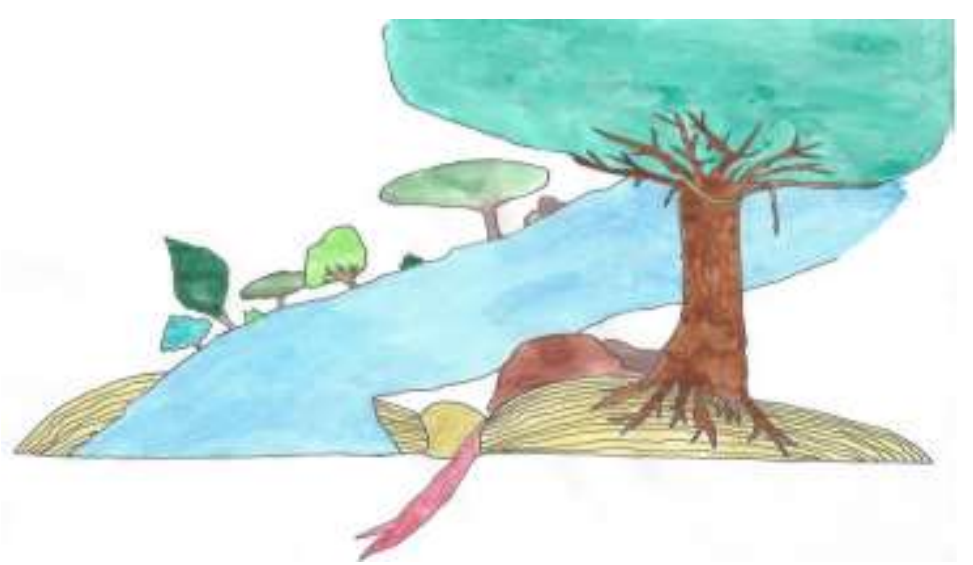

As nascentes, as matas ciliares, a reciclagem de materiais, o tempo de degradação dos materiais, o tamanho das áreas de preservação permanentes entre outros temas.

Adriano RemoriniTralback, Prof. Dr.Juliano José Corbi (Orientador) 


\section{Cartillha de Educação Ambiental}

Cartilha desenvolvida pelo Mestrando Adriano Remorini Tralback, sob a Supervisão e Orientação do Professor Doutor Juliano José Corbi, como "Produto Final" do Mestrado Profissional em Ciências Ambientais, através do Programa de Pós-Graduação em Rede Nacional para o Ensino de Ciências Ambientais, PROFCIAMB através da Escola de Engenharia de São Carlos, EESC, USP de São Carlos, em parceria com a Agência Nacional de Águas (ANA).

\section{PROFCAMB

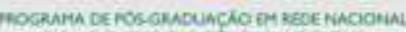

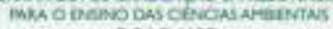 rocousp}

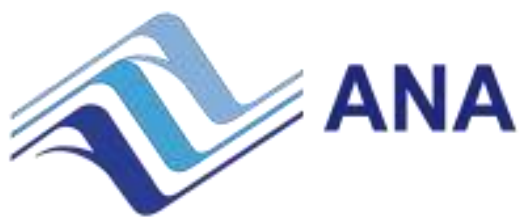
AGÊNCIA NACIONAL DEÁGUAS
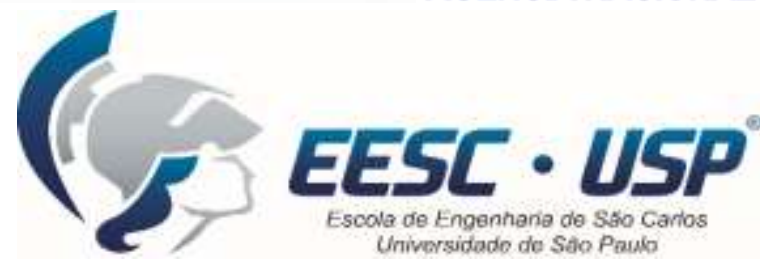

Escola de Engenharia de Sto Carios Universidado de Salo Paulo

\section{São Carlos - 2020}




\section{Índice}

\begin{tabular}{|l|l|}
\hline 1 - A importância de preservar as matas ciliares. & 6 \\
\hline 2 - Plantar árvores para não faltar água. & 7 \\
\hline 3 - As estruturas das folhas de uma árvore. & 11 \\
\hline $\begin{array}{l}4 \text { - Os estômatos e as trocas gasosas que ocorrem nas } \\
\text { plantas. }\end{array}$ & 12 \\
\hline 5 - Os tipos de corpos d'água. & 13 \\
\hline $\begin{array}{l}6 \text { - Proteger as nascentes, córregos rios é um dever de } \\
\text { todos. }\end{array}$ & 15 \\
\hline $\begin{array}{l}7 \text { - O tamanho da APP (Área de Preservação Permanente) } \\
\text { que deve ser deixado ao redor de nascentes, córregos, } \\
\text { riachos, rios e "lagos". }\end{array}$ & 16 \\
\hline $\begin{array}{l}8 \text { - Outras maneiras de cuidar de nascentes e outros } \\
\text { corpos d'água. }\end{array}$ & 24 \\
\hline 9 - O tempo de degradação dos materiais. & 25 \\
\hline 10 - A reciclagem de materiais. & 26 \\
\hline $\begin{array}{l}11 \text { - O papel dos bioindicadores para aferir a qualidade da } \\
\text { água em corpos d'água. }\end{array}$ & 29 \\
\hline 11.1 - Bioindicadores de ótima qualidade de água & 31 \\
\hline $\begin{array}{l}11.2 .- \text { Bioindicadores de qualidade média ou regular de } \\
\text { água }\end{array}$ & 34 \\
\hline $\begin{array}{l}11.3 \text { - Bioindicadores de qualidade péssima ou ruim de } \\
\text { água }\end{array}$ & 36 \\
\hline \begin{tabular}{l}
12 - Transdisciplinaridade envolvendo temas ambientais. \\
\hline 12.1 - Atividades para a fixação do aprendizado
\end{tabular} & 41 \\
\hline $\begin{array}{l}13 \text { - Entidades de credibilidade voltadas a Proteção do } \\
\text { Meio Ambiente e dos Animais. }\end{array}$ & 43 \\
\hline 14 - Referências. & 50 \\
\hline
\end{tabular}




\section{Cartilha de Educação Ambiental}

\section{Aplicações, Público Alvo, Competências e Habilidades}

A presente cartilha abordará sobre a Educação Ambiental referente a preservação de nascentes e mananciais, proteção de matas ciliares, reciclagem de materiais e sustentabilidade.

\section{Aplicacõos:}

O material foi produzido com o fim educacional e pode ser aplicado tanto dentro de salas de aula, como complemento a aulas de Ciências da Natureza, Biologia, Geografia e disciplinas correlatas, onde o professor poderá utilizar a cartilha, para que os alunos respondam a questões relativas ao Meio Ambiente e Educação Ambiental (vide parte final da Cartilha), como também poderá ser utilizado fora do ambiente escolar para os fins de pesquisa ambiental, nos mais variados fins.

\section{Público Alvo:}

Como público alvo, este estudo abrange tanto os alunos do Ensino Fundamental quanto Médio, bem como profissionais de outras áreas. 


\section{Competências:}

Dentre as competências que serão desenvolvidas com o uso da Cartilha: a presente cartilha tratará de assuntos e saberes relacionados as Ciências da Natureza (tipos de corpos d'água), Biologia (bio indicadores), e Educação Ambiental (reciclagem de materiais), Direito e Gestão Ambiental (tamanho das áreas das APP's).

\section{Habilidades:}

Como aplicação prática, esta cartilha poderá ser utilizada para identificar bio indicadores (insetos) presentes em fontes e cursos d'água, identificar as cores dos recipientes que são destinados a reciclagem de materiais, bem como o tempo "estimado" necessário para a degradação de materiais na Natureza, de acordo com cada tipo de material. 


\section{1 - A importância de preservar as matas ciliares:}

As matas ciliares, também conhecidas como "Florestas Ripárias", "Matas de Várzea" ou de "Galeria", "Matas Ribeirinhas", são o suporte para a existência de nascentes, córregos e Rios, conforme Figura 1 a seguir elencada:

Figura 1 - A mata ciliar:

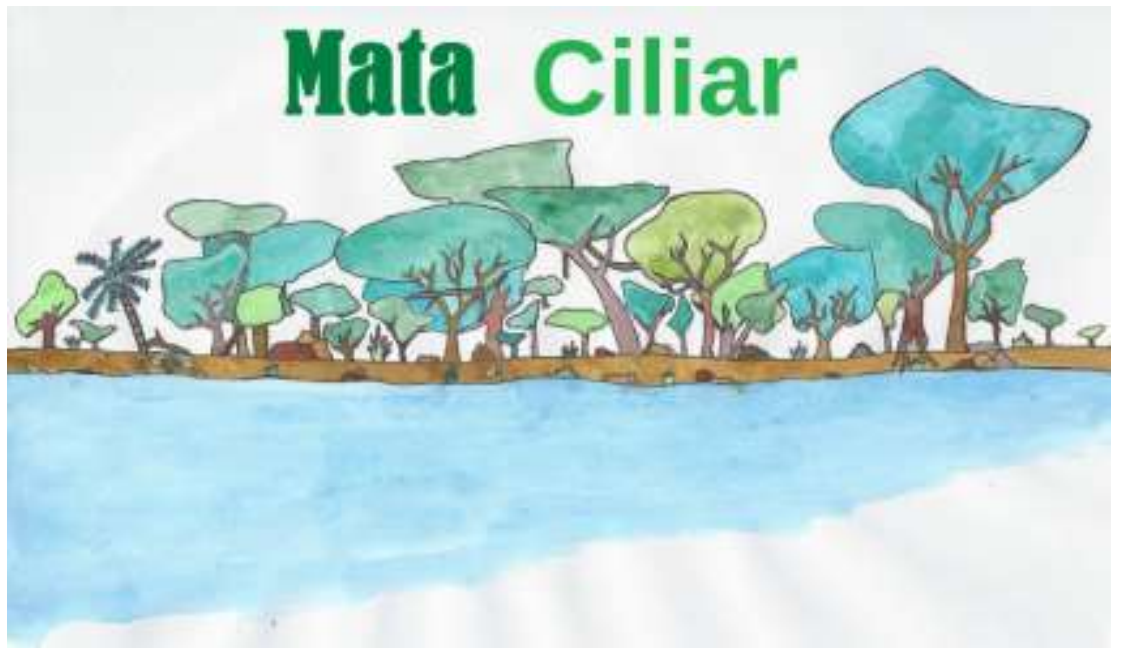

Fonte: Desenho feito pelo autor.

Além de evitarem o assoreamento, que é o acúmulo de sedimentos, pelo depósito de terra, areia, argila e demais detritos na calha de um rio, propiciam uma melhora considerável na qualidade da água existente nos corpos d'água quando se encontram presentes, proporcionam um aumento da quantidade de oxigênio existente na água, ajudam a corrigir o pH, ajudam no Ciclo do Nitrogênio, fazendo a conversão de amônia (NH3) (que é uma substância tóxica)em nitritos (NO2-) e nitratos (NO3 )(substâncias menos tóxicas), diminuem a condutividade elétrica da água, além de suas sombras ajudarem a baixar a temperatura da água, ou seja as matas ciliares ajudam a restabelecer o equilíbrio natural de uma nascente, córrego, riacho ou rio. 


\section{2 - Plantar árvores para não faltar água:}

Como foi informado no item anterior, as árvores são extremamente importantes para se garantir a proteção de nascentes e rios pois além de evitarem o assoreamento (acúmulo de sedimentos pelo depósito de terra, areia, argila ou detritos na calha de um rio ou lago), como mais uma das funções benéficas que são propiciadas pelas árvores, elas ajudam a proporcionar uma contínua devolução de água ao ambiente, através de seus processos de "Transpiração", "Respiração" e "Gutação" (eliminação de água nas margens e no ápice das folhas, através de estruturas especiais conhecidas como "hidatódios"*) que tornará o ambiente úmido, fazendo com que a água escorra novamente para o solo, contribuindo desta maneira para o aumento do fluxo de água nos corpos hídricos.

As Figuras 2 e 3 , a seguir, demonstram os Hidatódios, presentes em algumas espécies vegetais.

Figura 2 - Hidatódios, são porções de tecido fundamental das folhas diferenciadas em glândulas destinadas a expelir água com íons por estômatos modificados que se encontram nas pontas e nas margens das folhas de algumas espécies de plantas:

\section{HIDATÓdIOS}

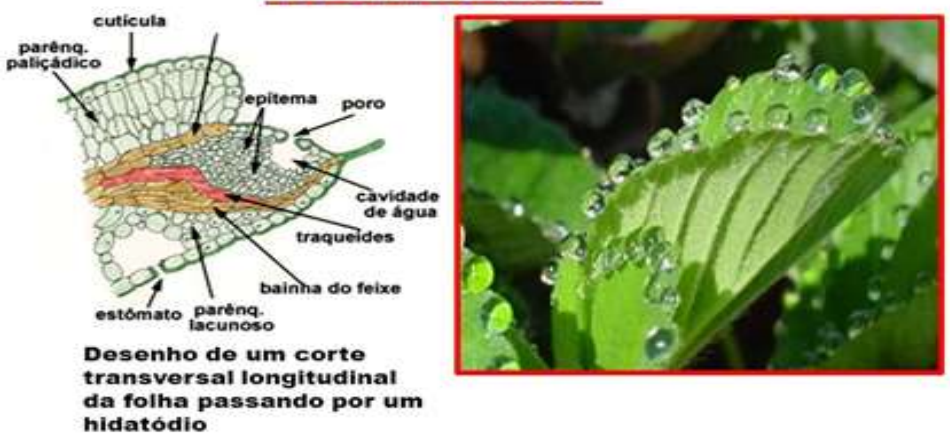

Fonte: BIANCHI, Disponível em

<https://slideplayer.com.br/slide/11130653/> acesso em 19 de abril de 2019. 
Figura 3 - Hidatódios:
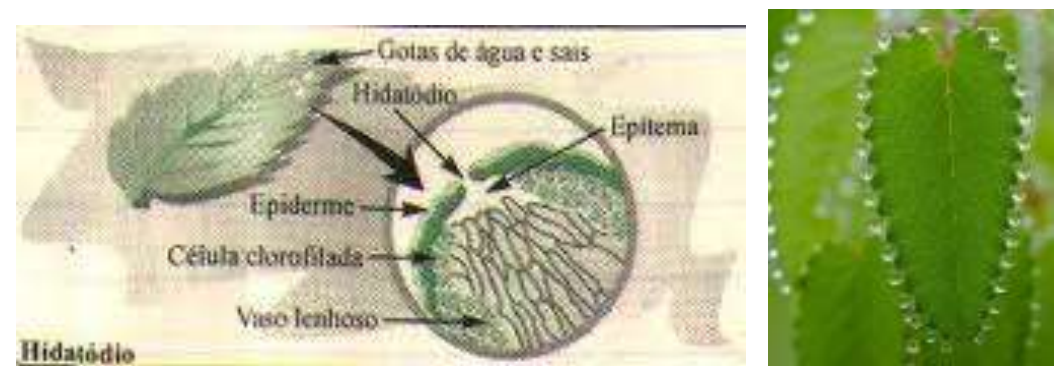

Fonte: Disponível em

<https://deskgram.net/explore/tags/guta\%C3\%A7\%C3\%A3o>, acesso

em 20 de abril de 2019.

* Hidatódios ou hidátodos são porções de tecido fundamental das folhas diferenciadas em glândulas destinadas a expelir água com íons por estômatos modificados que se encontram nas pontas e nas margens das folhas de algumas espécies de plantas. 
A Figura 4, a seguir elencada, demonstra a formação das bacias hidrográficas, através das nascentes formando os rios.

Figura 4 - Formação das Bacias Hidrográficas:

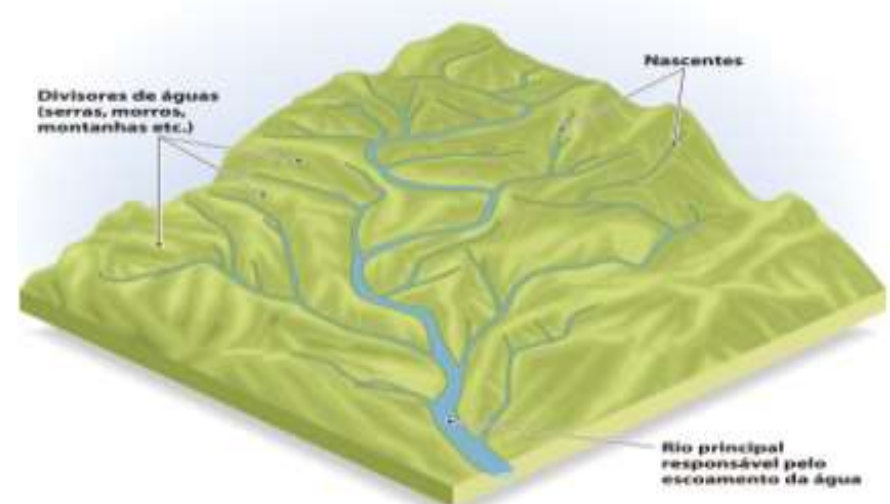

Fonte: Agência Nacional de Águas, Curso de Capacitação EAD, O caminho das águas".

A Figura 5, representa a declividade do terreno e escoamento das águas pluviais e provenientes dos processos de "Transpiração", "Respiração" e "Gutação" até os rios.

Figura 5 - Escoamento das águas até os rios:

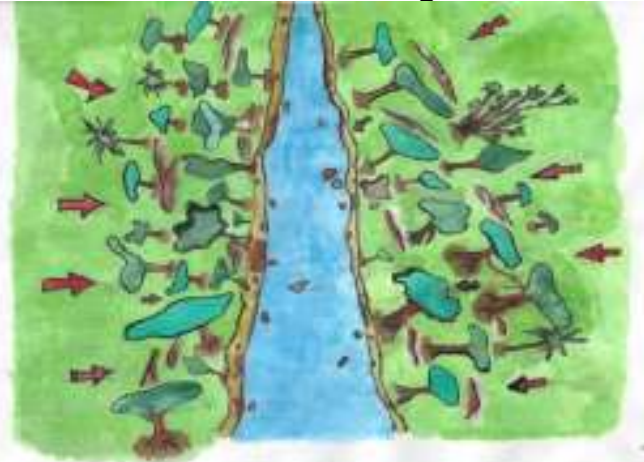

Fonte: Desenho feito pelo autor, representando o escoamento das águas para o rio. 
A Figura 6, a seguir elencada, demonstra os processos de infiltração de águas pluviais (águas provenientes das chuvas) para o solo, onde o escoamento em solos arenosos é maior que o escoamento da água que ocorre nos solos argilosos, devido a característica desse tipo de material (da argila). Os escoamentos das águas pluviais para o subsolo, também são influenciados pela declividade do terreno.

Figura 6 - Os processos de infiltração da água no solo:

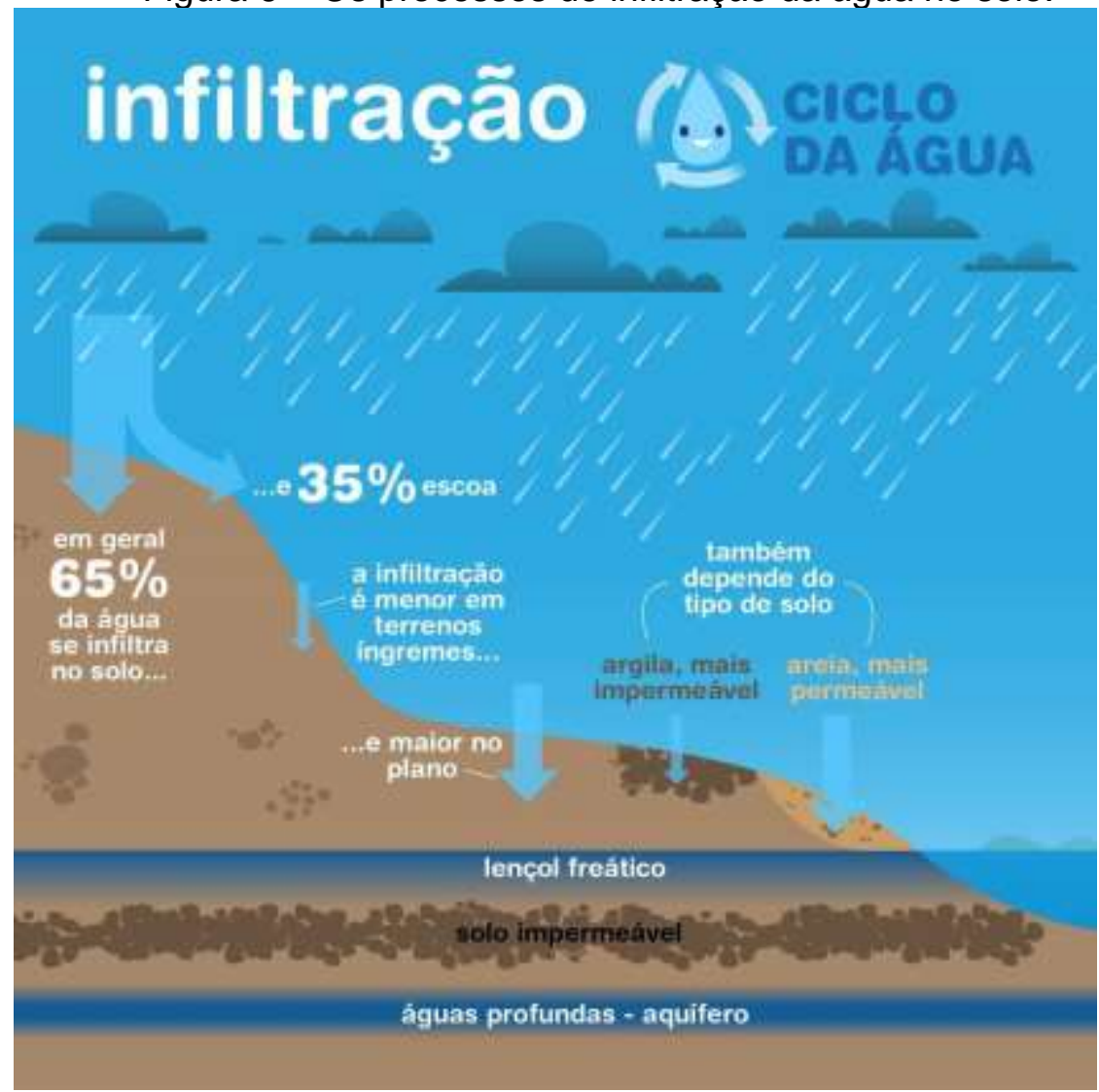

Fonte: "site" Água sua linda, disponível em <http://agua-sualinda.tumblr.com/post/139537685783/penetra-infiltrada-isso-que$\%$ C3\%A9-aproveitar 
3 - As estruturas das folhas de uma árvore:

A Figura 7, demonstra a seguir, as estruturas das folhas formando os "ramos" (galhos) de uma árvore.

Figura 7 - As estruturas das folhas de uma árvore:

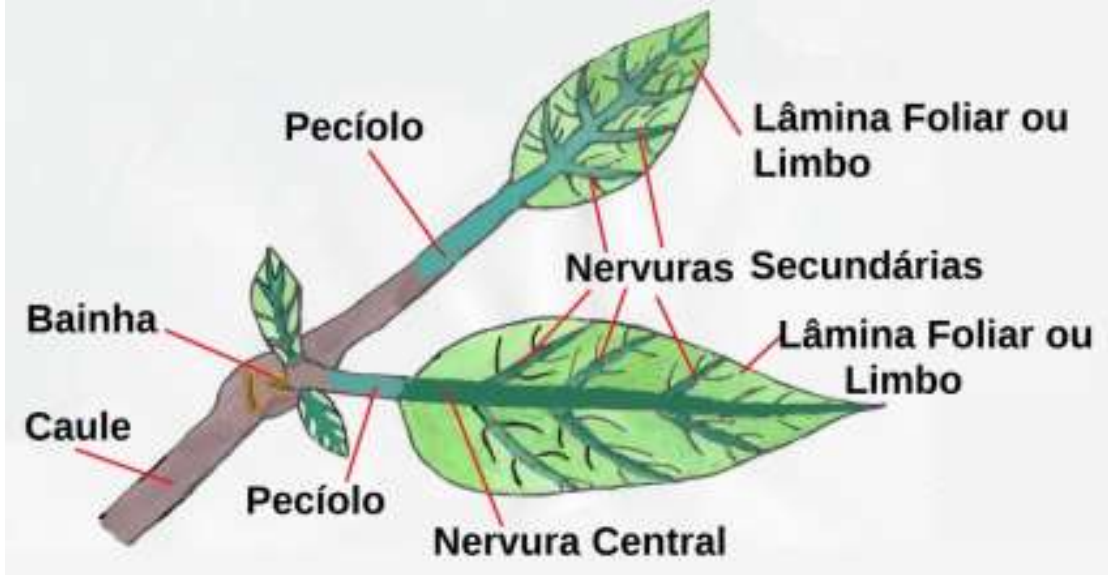

Fonte: "site" Info Escola, disponível em

<https:/www.infoescola.com/plantas/folhas> (figura adaptada).

\section{As folhas de uma árvore são compostas das seguintes estruturas:}

Bainha (local onde nascem os brotos);

Pecíolo (haste que segura a folha no galho);

Nervuras (Canais para transporte de substâncias orgânicas das folhas para a planta e da planta para as folhas);

Lâmina Foliar ou Limbo (Parte achatada e dilatada da folha responsável por receber a luz solar);

Caule (Estrutura que mantém seguro os "pecíolos" das folhas, formando os galhos das árvores); 


\section{4 - Os estômatos e as trocas gasosas que ocorrem nas plantas}

As Figuras 8 e 9, abaixo, demonstram os "estômatos" ou "estomas" que são estruturas microscópicas que permitem as trocas gasosas existentes entre a árvore e o meio ambiente, referente ao processo de Fotossíntese (durante o dia, na presença de luz), onde ocorre a entrada de gás carbônico e saída de oxigênio e da respiração da planta (durante a noite, sem a presença de luz) onde ocorrerá a entrada de oxigênio e a saída de gás carbônico.

Figura 8 - Estômatos ou estomas:

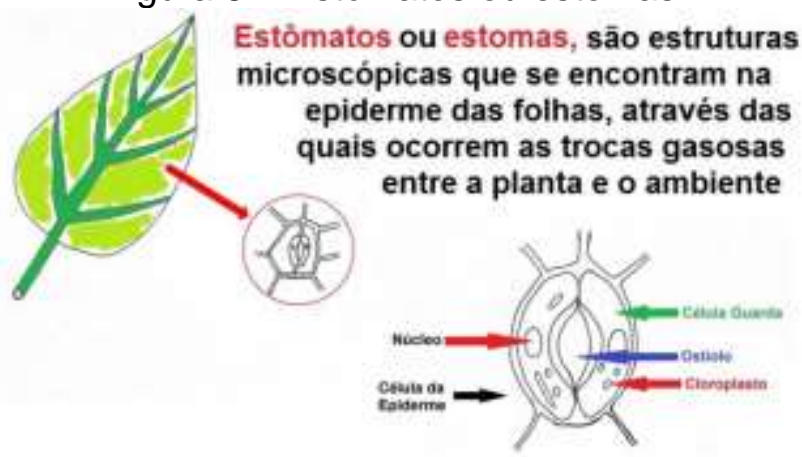

Fonte: "site" Instituto de Biologia UNESP, disponível em $<$ https://www2.ibb.unesp.br/nadi/Museu3_identidade/Museu3_identidad e_funcoes/Documentos/Museu3_funcoes_fotossintese.htm> (figura adaptada).

Figura 9 - As trocas gasosas que ocorrem nos estômatos:

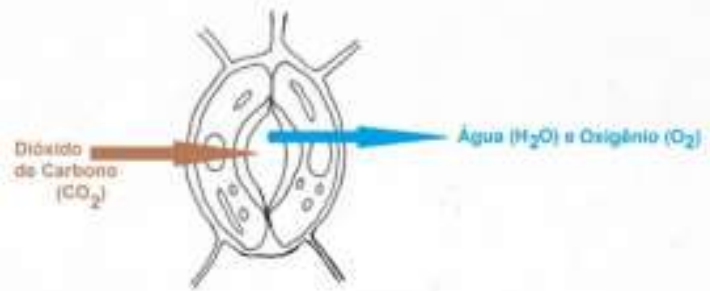

Fonte: "Blogspot" página "Ronald Biologia" disponível em $<$ http://ronaldbiologia.blogspot.com/2015/09/estomato.html> adaptada).

(figura 
As folhas além de desempenharem papeis relativos a Fotossíntese e Respiração, onde ocorre a troca de gases com o Ambiente, também tem a função de devolverem água ao ambiente através do processo de Transpiração:

A figura 10, a seguir elencada demonstra as trocas gasosas realizadas pelas plantas, através dos estômatos nas folhas:

Figura 10 - As trocas gasosas que ocorrem nas plantas:

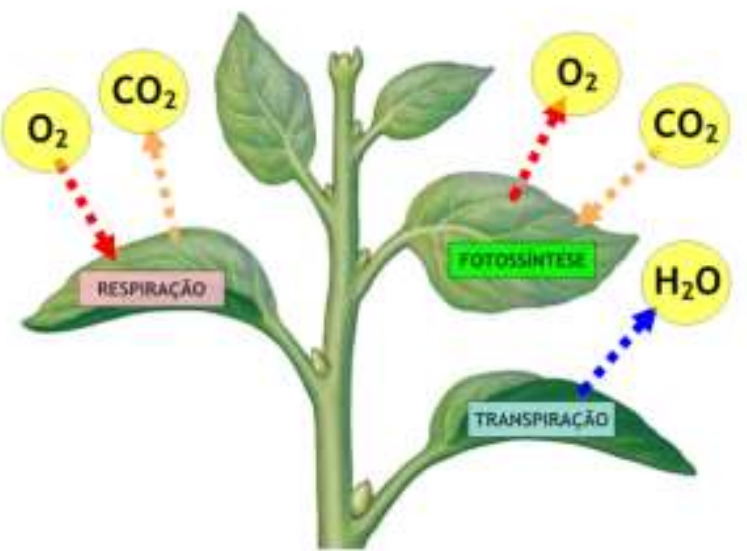

Fonte: PETRIN. Disponível em < https://www.estudopratico.com.br/transpiracao-vegetal-cuticular-eestomatica/>, acesso em 20 de abril de 2019.

\section{5 - Os tipos de corpos d'água:}

Os corpos d'água são classificados de acordo com o movimento ou não de suas águas.

Os corpos d'agua, que possuem "água parada", "sem movimento", ou seja sem troca constante de águas como os Lagos e lagoas, são chamados de "Ecossistemas Lênticos". 
Já os corpos d'agua que possuem "água em movimento", ou seja, água em intensa troca entre os ambientes aquático e terrestre, são chamados de "Ecossistemas Lóticos", esses tipos de ecossistemas envolvem as nascentes, os córregos, os riachos e rios.

As figuras 11 e 12 à seguir demonstram bem esses dois tipos de Ecossistemas, a Figura 11, demonstra os chamados "Ecossistemas Lênticos" (ecossistemas que possuem água parada, como os lagos, as lagoas) já a Figura 12, demonstra os chamados "Ecossistemas Lóticos" (que possuem água "em movimento", como as nascentes, os córregos, os riachos, os rios):

Figura 11 - Ecossistemas Lênticos:

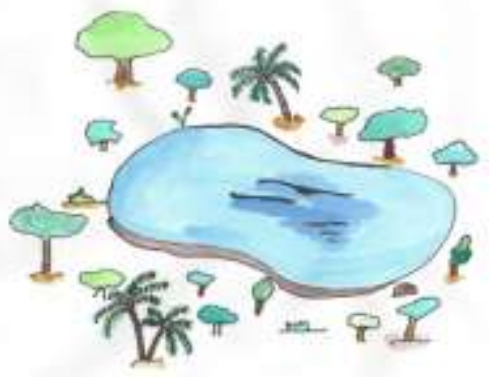

Ecossistemas Lênticos :

São ambientes aquáticos de àgua parada.

Exemplos: Lagos, Lagoas.
Figura 12 - Ecossistemas Lóticos:

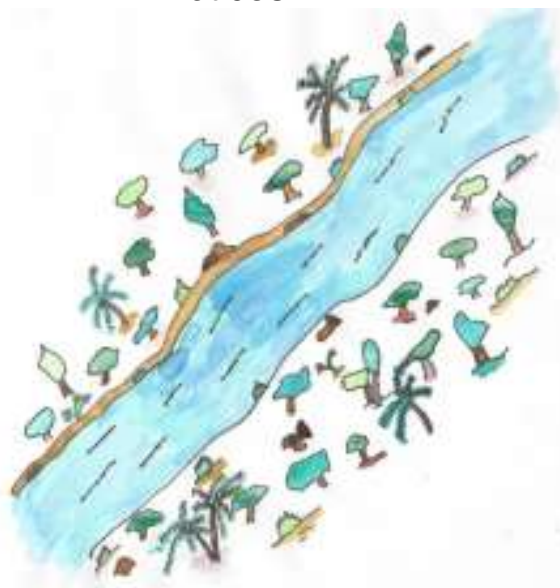

Ecossistemas Lóticos :

São ambientes aquáticos que possuem água em movimento.

Exemplos: Nascentes, Córregos, Riachos, Rios.

Fonte: Desenhos feitos pelo Autor. 


\section{6 - Proteger as Nascentes, Córregos Rios é um dever de todos:}

Figura 13 - O Plantio de árvores ajuda a preservar os mananciais e garantir a oferta de água para as futuras gerações:

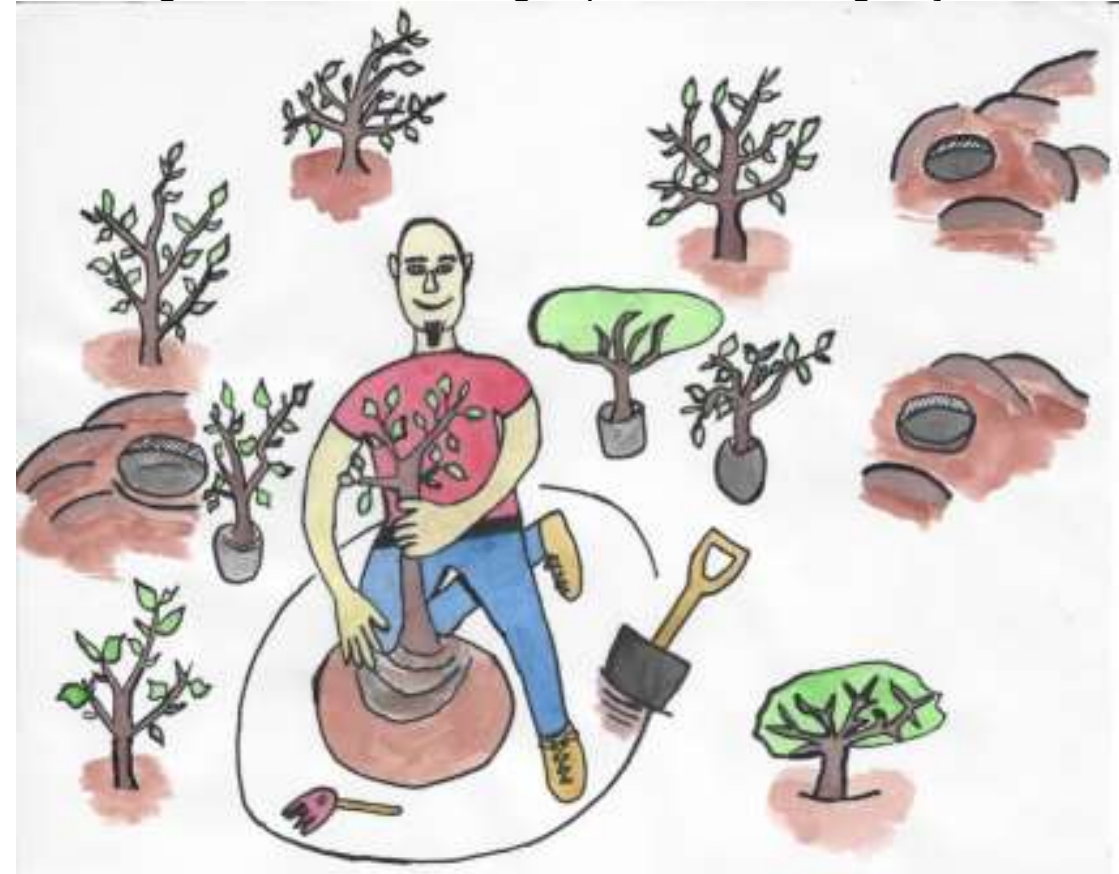

Fonte: Desenho feito pelo Autor.

Uma das principais formas de se proteger as nascentes, córregos, riachos e rios é através do plantio de árvores nativas próximas a estes locais, conforme demonstrado anteriormente, na Figura 13.

Porém antes de realizar o plantio de árvores deve ser realizado um estudo ambiental a respeito da área a qual se deseja reflorestar como também das árvores nativas existentes na região para que seja evitado com isso a introdução no local de novas 
espécies, principalmente espécies conhecidas como "invasoras" (que não são nativas daquele local) e podem colocar em risco no caso da multiplicação dessas espécies o equilíbrio de todo o Ecossistema existente no local e na região, haja vista que as espécies invasoras, podem acabar dominando o antigo local em que foram implantadas, vencendo de forma desigual competições naturais relativas ao desenvolvimento de árvores, o que acaba por vezes "sufocando" o crescimento de muitas espécies nativas, em relação a busca da luz solar para o desenvolvimento da planta, disseminação de sementes, que na maioria das vezes no tocante a espécies invasoras acaba sendo mais facilitada face as espécies não serem nativas daquele local, a preocupante mudança de hábitos alimentares na fauna existente, prejudicando os hábitos alimentares dos animais.

\section{7 - O tamanho da APP (Área de Preservação Permanente) que deve ser deixado ao redor de nascentes, córregos, riachos, rios e "lagos"*:}

Quanto as chamadas APP's, que são áreas de preservação permanente, ou seja, áreas contendo a mata ciliar que devem ser deixadas "intocadas", ou seja, nessas áreas próximas de nascentes, córregos, riachos, rios e "lagos"* não poderá ocorrer o desmatamento da mata ciliar, sob pena de ser aplicada uma rigorosa multa ambiental, além da exigência do replantio com espécies nativas.

\section{Observação:}

* Quanto aos lagos existem situações específicas que são aplicadas, inclusive no que se refere a lagos artificiais, inclusive os que não dependem do barramento ou represamento de cursos d'água naturais.

Quem define o tamanho da área de preservação permanente que deve ser deixada próxima dos corpos d'água é a 
Lei no 12.651 , de 25 de maio de 2012, em seu artigo $4^{\circ}$, que assim define:

\section{LEI № 12.651, DE 25 DE MAIO DE 2012.}

Dispõe sobre a proteção da vegetação nativa; altera as Leis $\mathrm{n}$ os 6.938 , de 31 de agosto de 1981, 9.393, de 19 de dezembro de 1996, e 11.428, de 22 de dezembro de 2006; revoga as Leis nos 4.771 , de 15 de setembro de 1965 , e 7.754, de 14 de abril de 1989, e a Medida Provisória № 2.166-67, de 24 de agosto de 2001; e dá outras providências.

\section{CAPÍTULO II}

\section{DAS ÁREAS DE PRESERVAÇÃO PERMANENTE}

\section{Seção I}

\section{Da Delimitação das Áreas de Preservação Permanente}

Art. 4 - Considera-se Área de Preservação Permanente, em zonas rurais ou urbanas, para os efeitos desta Lei:

I - as faixas marginais de qualquer curso d'água natural perene e intermitente, excluídos os efêmeros, desde a borda da calha do leito regular, em largura mínima de:

(Incluído pela Lei $n^{\circ}$ 12.727, de 2012).

a) 30 (trinta) metros, para os cursos d'água de menos de 10 (dez) metros de largura;

b) 50 (cinquenta) metros, para os cursos d'água que tenham de 10 (dez) a 50 (cinquenta) metros de largura; 
c) 100 (cem) metros, para os cursos d'água que tenham de 50 (cinquenta) a 200 (duzentos) metros de largura;

d) 200 (duzentos) metros, para os cursos d'água que tenham de 200 (duzentos) a 600 (seiscentos) metros de largura;

e) 500 (quinhentos) metros, para os cursos d'água que tenham largura superior a 600 (seiscentos) metros;

II - as áreas no entorno dos lagos e lagoas naturais, em faixa com largura mínima de:

a) 100 (cem) metros, em zonas rurais, exceto para o corpo d'água com até 20 (vinte) hectares de superfície, cuja faixa marginal será de 50 (cinquenta) metros;

b) 30 (trinta) metros, em zonas urbanas;

III - as áreas no entorno dos reservatórios d'água artificiais, decorrentes de barramento ou represamento de cursos d'água naturais, na faixa definida na licença ambiental do empreendimento; (Incluído pela Lei oㅜ 12.727, de 2012).

IV - as áreas no entorno das nascentes e dos olhos d'água perenes, qualquer que seja sua situação topográfica, no raio mínimo de 50 (cinquenta) metros; Lei ํo 12.727, de 2012).

$\mathrm{V}$ - as encostas ou partes destas com declividade superior a $45^{\circ}$, equivalente a $100 \%$ (cem por cento) na linha de maior declive;

$\mathrm{VI}$ - as restingas, como fixadoras de dunas ou estabilizadoras de mangues;

VII - os manguezais, em toda a sua extensão; 
VIII - as bordas dos tabuleiros ou chapadas, até a linha de ruptura do relevo, em faixa nunca inferior a 100 (cem) metros em projeções horizontais;

IX - no topo de morros, montes, montanhas e serras, com altura mínima de 100 (cem) metros e inclinação média maior que $25^{\circ}$, as áreas delimitadas a partir da curva de nível correspondente a 2/3 (dois terços) da altura mínima da elevação sempre em relação à base, sendo está definida pelo plano horizontal determinado por planície ou espelho d'água adjacente ou, nos relevos ondulados, pela cota do ponto de sela mais próximo da elevação;

$X$ - as áreas em altitude superior a 1.800 (mil e oitocentos) metros, qualquer que seja a vegetação;

$X I$ - em veredas, a faixa marginal, em projeção horizontal, com largura mínima de 50 (cinquenta) metros, a partir do espaço permanentemente brejoso e encharcado. dada pela Lei no 12.727, de 2012).

$\S 1$ - Não será exigida Área de Preservação Permanente no entorno de reservatórios artificiais de água que não decorram de barramento ou represamento de cursos d'água naturais. (Redação dada pela Lei no 12.727 , de 2012). de 2012).

$\S 2^{2}$ - (Revogado).

(Redação dada pela Lei no 12.727 ,

§ 3 - (VETADO).

§ 4 Nas acumulações naturais ou artificiais de água com superfície inferior a 1 (um) hectare, fica dispensada a reserva da faixa de proteção prevista nos incisos II e III do caput, vedada nova supressão de áreas de vegetação nativa, salvo autorização do órgão ambiental competente do Sistema Nacional do Meio 
Ambiente - Sisnama.

2012).

$\S 5$ - É admitido, para a pequena propriedade ou posse rural familiar, de que trata o inciso $V$ do art. 3o desta Lei, o plantio de culturas temporárias e sazonais de vazante de ciclo curto na faixa de terra que fica exposta no período de vazante dos rios ou lagos, desde que não implique supressão de novas áreas de vegetação nativa, seja conservada a qualidade da água e do solo e seja protegida a fauna silvestre.

A Figura 14, a seguir, demonstra através de desenhos, conforme a Lei Ambiental em vigor (artigo 4을 da Lei no 12.651, de 25 de maio de 2012), os tamanhos mínimos, referentes as matas ciliares que devem ser mantidas em relação ao tamanho do corpo d'água (o tamanho dos córregos, riachos e rios). 
Figura 14 - Tamanhos mínimos referentes a matas ciliares que devem ser mantidas próximos a corpos d'água (córregos, riachos e rios):

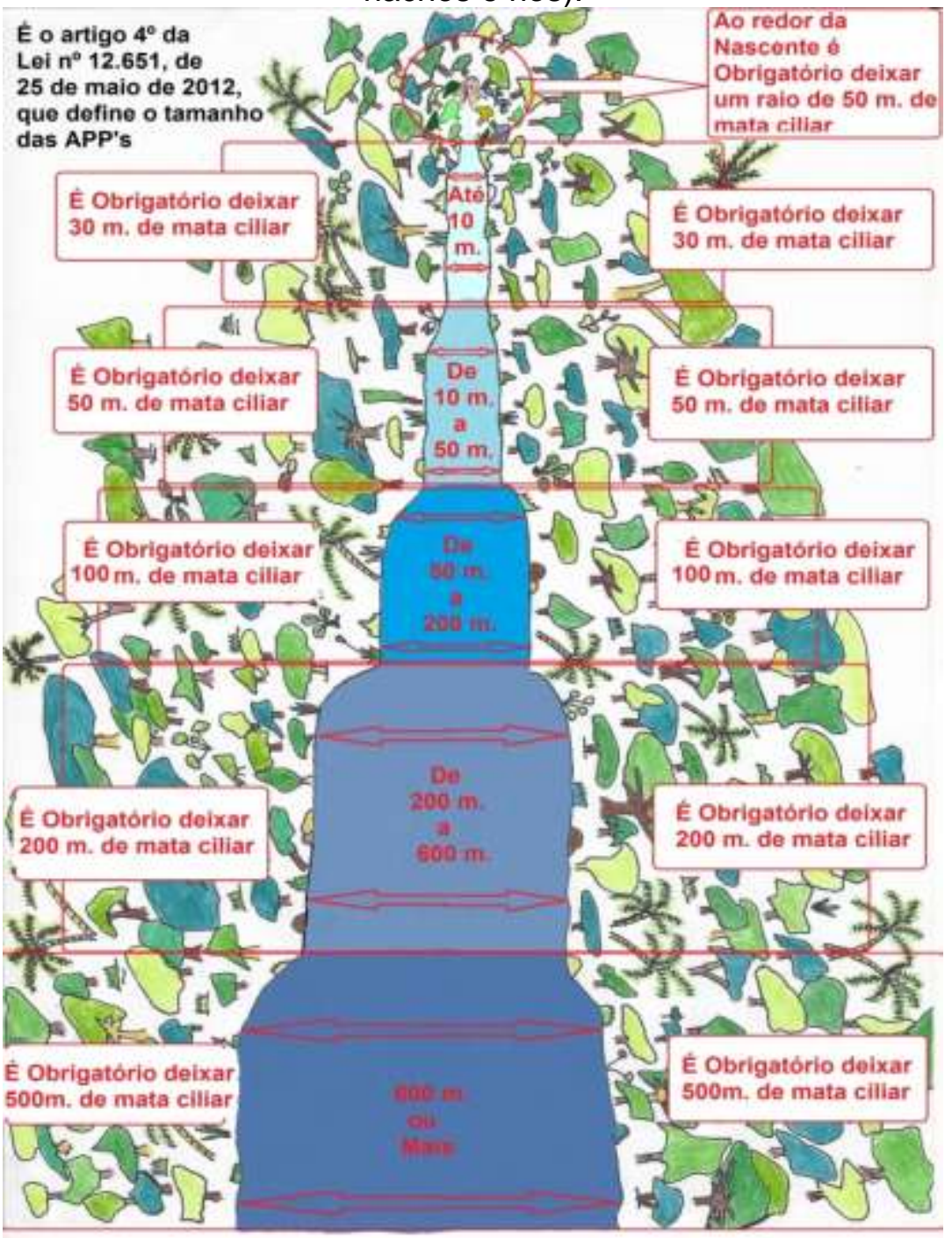

Fonte da Imagem: site "Inteliagro" Disponível em $<$ http://inteliagro.com.br/quanto-deve-medir-uma-app-area-de-preservacaopermanente-de-um-rio/>, acesso em 20 de abril de 2019. (figura adaptada). 
Quanto ao tema, interessante também o artigo quinto da Lei no 12.651, de 25 de maio de 2012, que trata sobre os reservatórios artificiais destinados a geração de energia elétrica ou abastecimento público

Art. $5^{\circ} \mathrm{Na}$ implantação de reservatório d'água artificial destinado a geração de energia ou abastecimento público, é obrigatória a aquisição, desapropriação ou instituição de servidão administrativa pelo empreendedor das Áreas de Preservação Permanente criadas em seu entorno, conforme estabelecido no licenciamento ambiental, observando-se a faixa mínima de 30 (trinta) metros e máxima de 100 (cem) metros em área rural, e a faixa mínima de 15 (quinze) metros e máxima de 30 (trinta) metros em área urbana. 2012). 
A Figura 15, também demonstra através de desenhos, conforme a Lei Ambiental em vigor (artigo 5o da Lei oㅜ 12.651, de 25 de maio de 2012), os tamanhos mínimos, referentes as matas ciliares que devem ser mantidas em relação ao tamanho do corpo d'água (o tamanho de lagos e reservatórios naturais e artificiais).

Figura 15 - Tamanhos mínimos referentes a matas ciliares que devem ser mantidas próximos a corpos d'água (lagos e reservatórios naturais e artificiais):

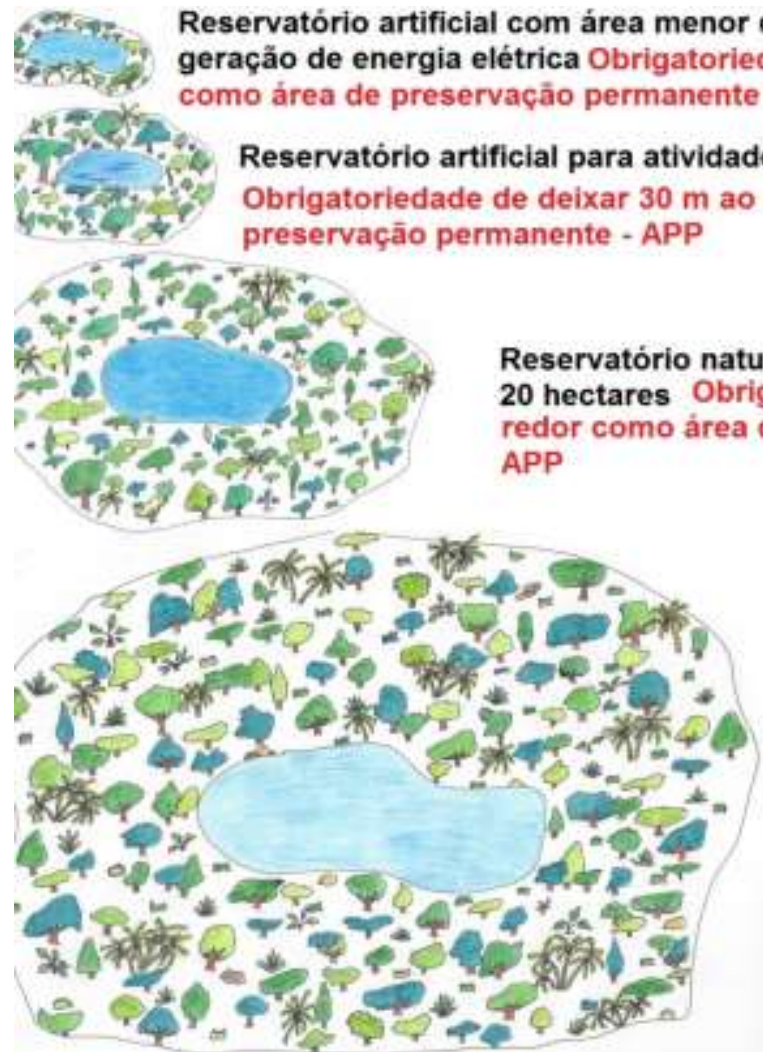

Reservatório artificial com 5 hectares utilizado para abstecimento público

Obrigatoriedade de deixar $100 \mathrm{~m}$ ao redor como área de preservaçāo permanente - APP

Fonte da Imagem: Site "inteliagro" Disponível em $<$ http://inteliagro.com.br/quanto-deve-medir-uma-app-area-depreservacao-permanente-de-um-rio/>, acesso em 20 de abril de 2019. (imagem adaptada). 


\section{8 - Outras maneiras de cuidar de nascentes e outros corpos d'água:}

Outras maneiras é cuidar para que não sejam jogados em nascentes e outros corpos d'água, lixo, materiais orgânicos e outros materiais poluentes.

A Figura 16, abaixo, demonstra a prática indevida de jogar lixo, em locais impróprios o que causa um grave aumento na poluição tanto do solo quanto dos corpos d'água, impactando a natureza e prejudicando todo o meio ambiente, além de estar praticando um crime ambiental (artigo 54, da Lei no 9.605, de 12 de fevereiro de 1998), sujeito a uma punição.

Figura 16 - Jogando lixo em local impróprio, causando graves danos ambientais:

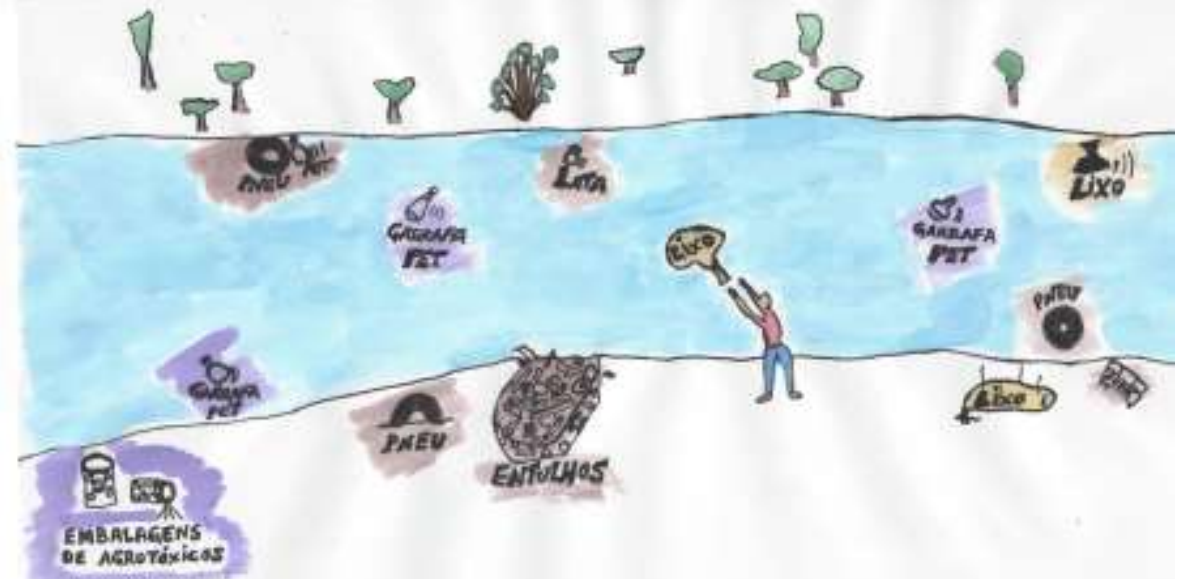

Fonte: Desenho feito pelo Autor.

A Figura 16 acima, representa a ação devastadora do homem (ação antrópica) referente a poluição ambiental. No desenho pode-se verificar que além do lixo que é jogado no rio, foram jogados também alguns materiais que apresentam perigo 
a todas as espécies como os agrotóxicos (defensivos agrícolas) bem como vários outros objetos que podem e devem ser reciclados, sendo que dessa forma além de proteger o meio ambiente podem gerar renda com a venda e o reaproveitamento dos materiais recicláveis colaborando dessa maneira com toda a sustentabilidade.

\section{9 - O Tempo de Degradação dos Materiais:}

Todos os materiais tem um tempo de vida útil na Natureza, após esse tempo, os materiais começam a se degradar (estragar, deteriorar, degenerar-se), onde o material deixa de existir.

Todos os materiais, possuem elementos químicos formando as estruturas que os constituem (Estrutura da Matéria), onde com o passar do tempo, ocorrem reações químicas que esses materiais acabam sofrendo, inclusive quando estão expostos, em contato direto com a natureza, sofrendo a ação da mesma, o que pode acelerar ainda mais essa degradação dos materiais (como as mudanças de tempo (tempo seco, tempo chuvoso), as variações de temperatura, etc...).

Em virtude disso, foram realizados então, alguns estudos relacionados a esse tempo de vida útil dos materiais que varia em relação de um material para outro.

De acordo com alguns estudos que foram realizados o tempo de degradação referente aos materiais na Natureza foi definido conforme a Figura 17 a seguir: 
Figura 17 - Tempo de degradação dos materiais:

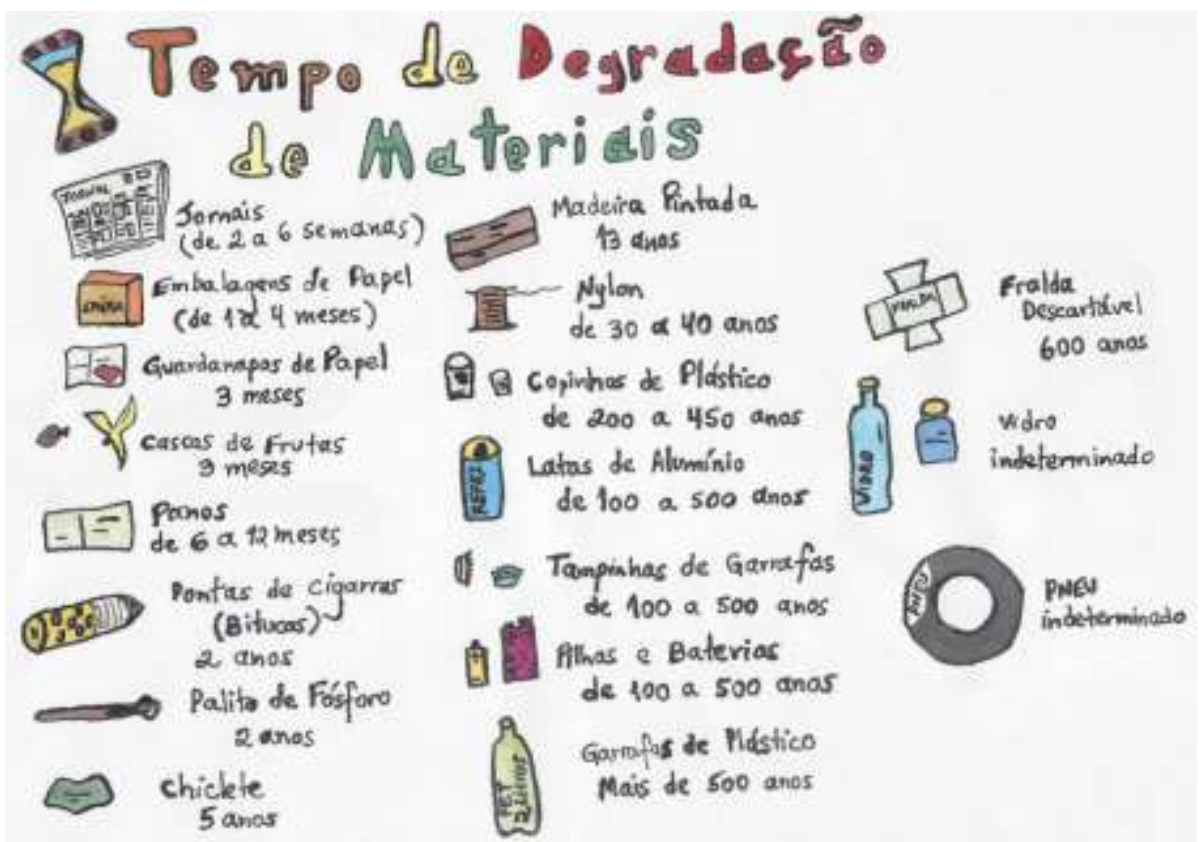

Fonte da Imagem: (Grippi 2001) disponível em $<$ http://www.fec.unicamp.br/ crsfec/tempo_degrada.html> acesso em 19 de abril de 2019. (figura adaptada).

\section{0 - A Reciclagem de Materiais:}

Quando se trata de reciclagem de materiais existem vários pontos de coletas, onde os materiais são separados de acordo com o seu tipo e características.

Foram definidas, através da resolução Conama (Conselho Nacional do Meio Ambiente) № 275, de 25 de abril de 2001, algumas cores referentes a reciclagem dos materiais, as principais são: 
Recipientes de coleta de reciclagem na Cor Amarela para os metais;

Recipientes de coleta de reciclagem na Cor Verde para os vidros;

Recipientes de coleta de reciclagem na Cor Azul para os papéis;

Recipientes de coleta de reciclagem na Cor Vermelha para os plásticos;

Recipientes de coleta de reciclagem na Cor Marrom para os orgânicos;

A Figura 18, demonstra alguns recipientes com as suas respectivas cores de acordo com o tipo de material a ser recebido, utilizados na coleta de materiais reciclados.

Figura 18 - recipientes mais comuns utilizados na coleta de materiais reciclados:

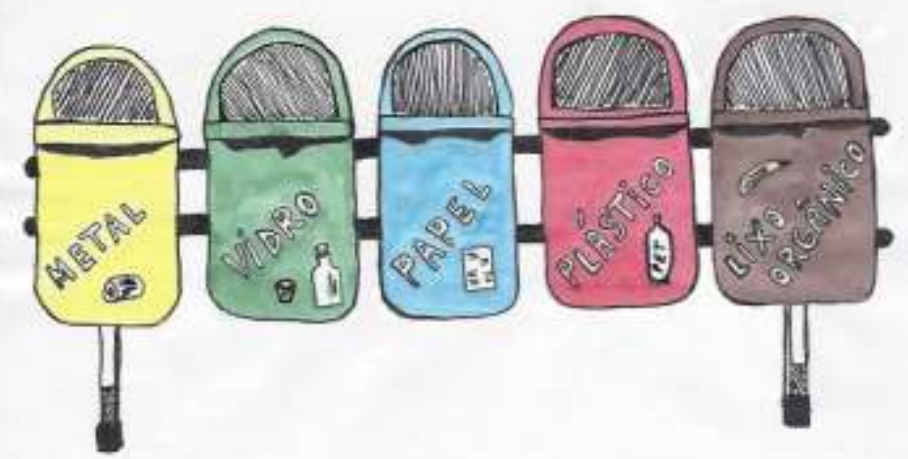

Fonte: Desenho feito pelo Autor. 
As demais cores de identificação usadas nos recipientes destinados a coleta de materiais:

\section{Azul = papel/papelão}

Vermelho $=$ plástico

Verde $=$ vidro

Amarelo = metal

Preto $=$ madeira

Laranja = Materiais perigosos ou contaminados;

Branco = Ambulatórios ou serviços de saúde;

Roxo $=$ materiais radioativos;

Marrom = materiais orgânicos como restos de alimentos;

Cinzar $=$ resíduos não recicláveis ou misturados ou contaminado, não passível de separação.

A Figura 19 a seguir, demonstra as demais cores que são utilizadas como identificação nos recipientes destinados a coleta de materiais, conforme a resolução Conama (Conselho Nacional do Meio Ambiente) nํ2ㄴ, de 25 de abril de 2001: 
Figura 19 - recipientes destinados a coleta de materiais, com diferentes "cores", cores essas, que são utilizadas para facilitar a identificação do tipo de material que é coletado, conforme a resolução Conama (Conselho Nacional do Meio Ambiente) ํㅜ 275, de 25 de abril de 2001:
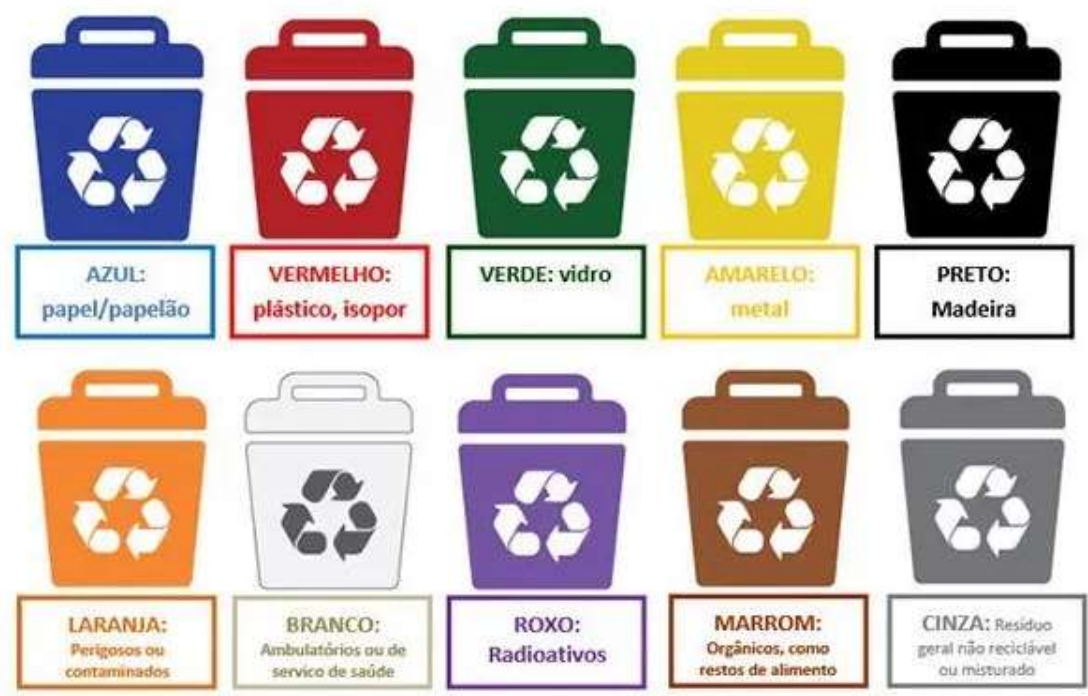

Fonte da Imagem: "site" lar plásticoshttps://www.larplasticos.com.br/conheca-as-cores-das-lixeirasde-coleta-seletiva/.

\section{1 - O papel dos bioindicadores para aferir a qualidade da água em corpos d'água:}

$\mathrm{Na}$ natureza existem os chamados "bioindicadores" os quais como o próprio nome já diz, são indicadores biológicos da qualidade da água.

Os "bioindicadores" vão desde insetos a seres microscópicos, cuja a presença de determinadas espécies, bem 
como a sua quantidade existente, servem para aferir a qualidade da água existente nas nascentes, córregos, riachos, rios e lagos. Qualidade esta que pode variar desde ótima, média ou regular e ruim ou péssima.

A Figura 20, demonstra o desenho de alguns insetos, classificados como "bioindicadores" da qualidade da água, cuja a presença de algumas espécies desses insetos facilitam a identificação da qualidade da água existe no corpo d'água.

Figura 20 - "bioindicadores" (algumas espécies de insetos) que facilitam a identificação da qualidade da água nos corpos d'água:

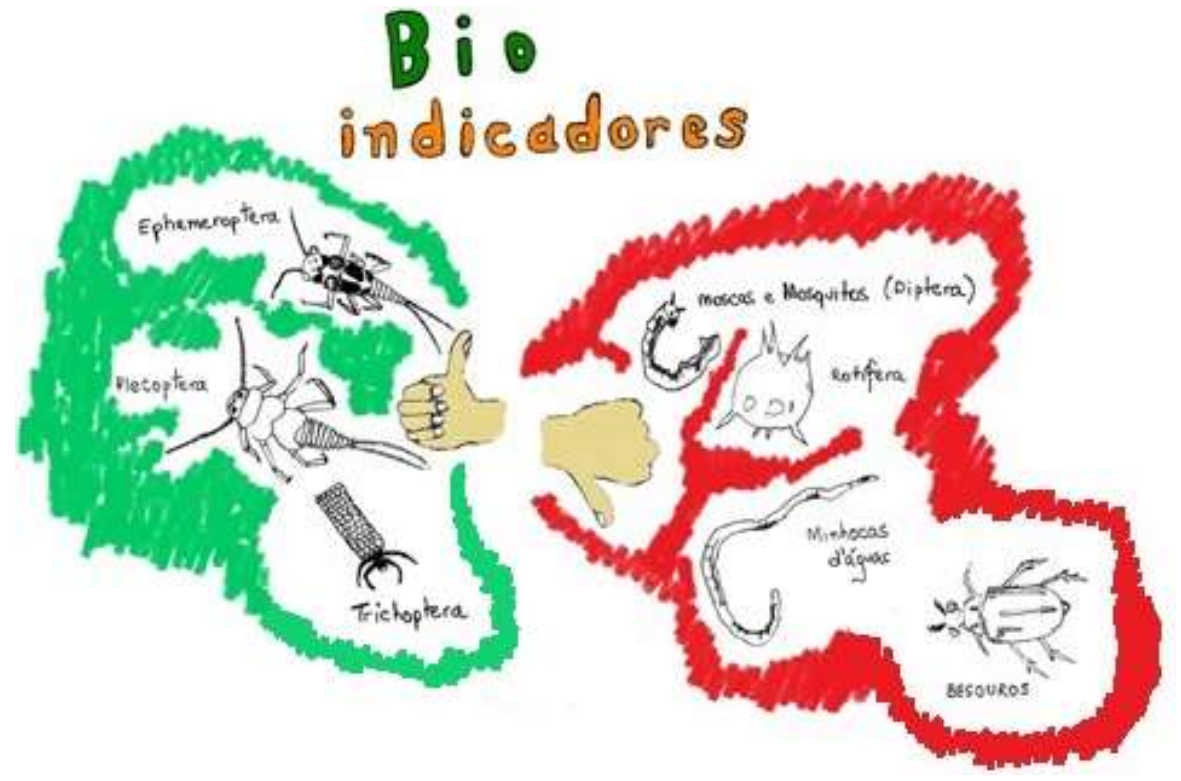

Fonte: CALLISTO, Marcos et al, Bioindicadores de qualidade de água, (cartilha, 19 p. produzida pela Universidade Federal de Minas Gerais) figura adaptada. 


\section{1 - Bioindicadores de Ótima Qualidade de Água:}

A presença dos "bioindicadores" representados nas imagens à seguir, em corpos d'água, indica uma Qualidade de Água de Nível Ótimo.

As Figuras 21, 22, 23, 24 e 25 trazem os desenhos de alguns insetos considerados bioindicadores cuja a presença dos mesmos nos corpos d'água indicam uma ótima qualidade de água, inclusive a EMBRAPA (Empresa Brasileira de Pesquisa Agropecuária), a qual é a autora e produziu os desenhos referenciados, atribuiu um "score" (uma graduação de "pontos") para cada espécie de insetos que são encontrados no corpo d'água, graduação de "scores" (de pontos) esta, que ajuda na classificação da qualidade da água do corpo d'água, a ser analisado:

Figura 21 - Inseto pertencente a Ordem "Megaloptera", bioindicador de uma ótima qualidade de água :

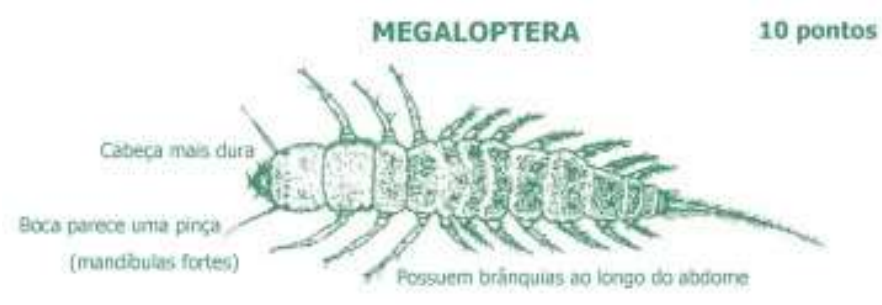

Geralmente s5o enccotrados em agua de boa e media qualidade

(Famila Corydalicae)

Fonte: Disponível em <https://www.embrapa.br/contandociencia/agua/-/asset_publisher/EljijRSeHvoC/content/bioindicadoresde-qualidade-de-agua/1355746? inheritRedirect=false > acesso em 19 de abril de 2019. 
Figura 22 - Inseto pertencente a Ordem "Plecoptera", bioindicador de uma ótima qualidade de água :

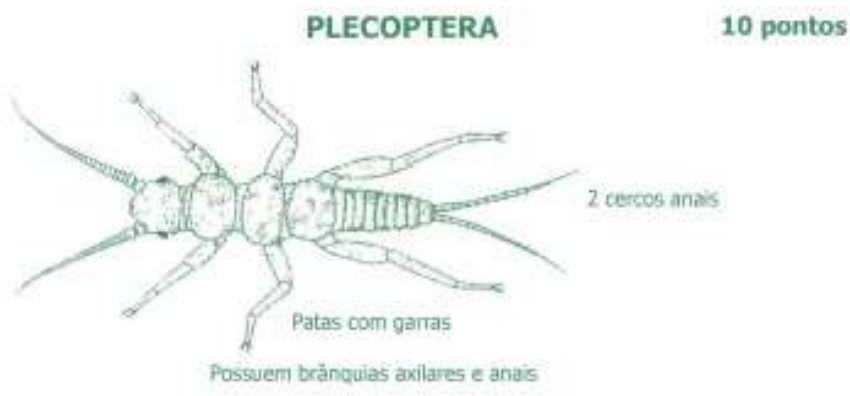

Geraimerte sào encontrados em águas de boa qualidade

Fonte: Disponível em <https://www.embrapa.br/contandociencia/agua/-/asset_publisher/EljjNRSeHvoC/content/bioindicadoresde-qualidade-de-agua/1355746?inheritRedirect=false > acesso em 19 de abril de 2019.

Figura 23 - Inseto pertencente a Ordem "Ephemeroptera", bioindicador de uma ótima qualidade de água :

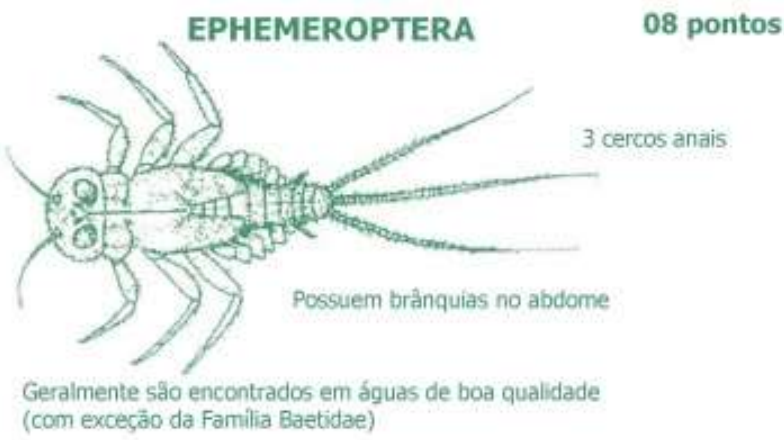

Fonte: Disponível em <https://www.embrapa.br/contandociencia/agua/-/asset_publisher/EljjNRSeHvoC/content/bioindicadoresde-qualidade-de-agua/1355746? inheritRedirect=false $>$ acesso em 19 de abril de 2019. 
Figura 24 - Inseto pertencente a Ordem "Lepidoptera", bioindicador de uma ótima qualidade de água :

\section{LEPIDOPTERA 08 pontos}

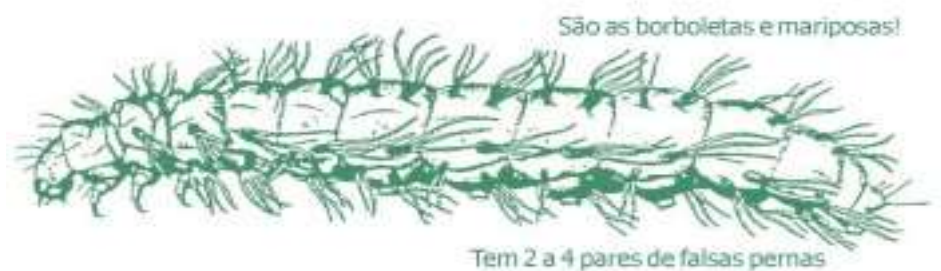

Escondem-se embaixo de pedras e plantas aquáticas

Só um grupo se desenvolve na àgua: Familia Pyralidae

Geraimente sào encontrados em água de boa qualidade

Fonte: Disponível em <https://www.embrapa.br/contandociencia/agua/-/asset_publisher/EljiNRSeHvoC/content/bioindicadoresde-qualidade-de-agua/1355746?inheritRedirect=false > acesso em 19 de abril de 2019.

Figura 25 - Inseto pertencente a Ordem "Trichoptera", bioindicador de uma ótima qualidade de água :

TRICHOPTERA

08 pontos

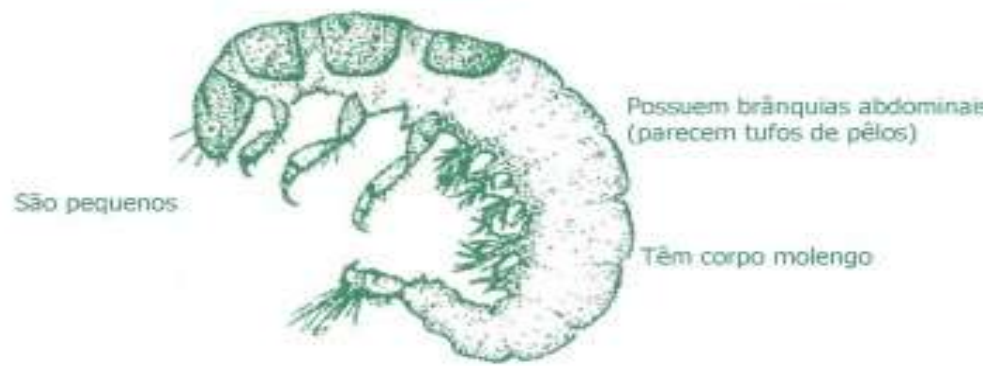

Podem ser encontrados dentro de casinhas (feitas por eles) de grăos de areá, gravetos, folhas e pequenas pedras

Geralmente sào encontrados em àgua de boa qualidade, mas também aparecem ent Gguas mais ou menos poluidas

Fonte: Disponível em <https://www.embrapa.br/contandociencia/agua/-/asset_publisher/EljiNRSeHvoC/content/bioindicadoresde-qualidade-de-agua/1355746? inheritRedirect=false $>$ acesso em 19 de abril de 2019. 


\section{2 - Bioindicadores de Qualidade Média ou Regular de Água:}

As Figuras 26, 27 e 28, a seguir elencadas, caracterizam o desenho de alguns insetos considerados "bioindicadores", cuja a presença dos mesmos nos corpos d'agua indicam uma Qualidade de Água de Nível Médio:

Figura 26 - Inseto pertencente a Ordem "Odonata", Sub ordem "Anysoptera" bioindicador de uma qualidade de água média ou regular:

\section{ODONATA (Sub ordem Anysoptera) 06 pontos}

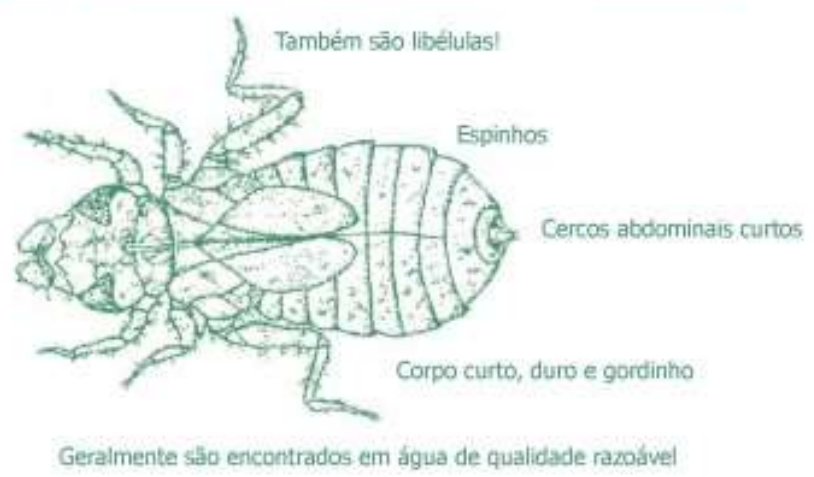

Fonte: Disponível em <https://www.embrapa.br/contandociencia/agua/-/asset_publisher/EljjNRSeHvoC/content/bioindicadoresde-qualidade-de-agua/1355746? inheritRedirect=false $>$ acesso em 19 de abril de 2019. 
Figura 27 - Inseto pertencente a Ordem "Odonata", Sub ordem "Zygoptera" bioindicador de uma qualidade de água média ou regular:

ODONATA (Sub ordem Zygoptera)

06 pontos

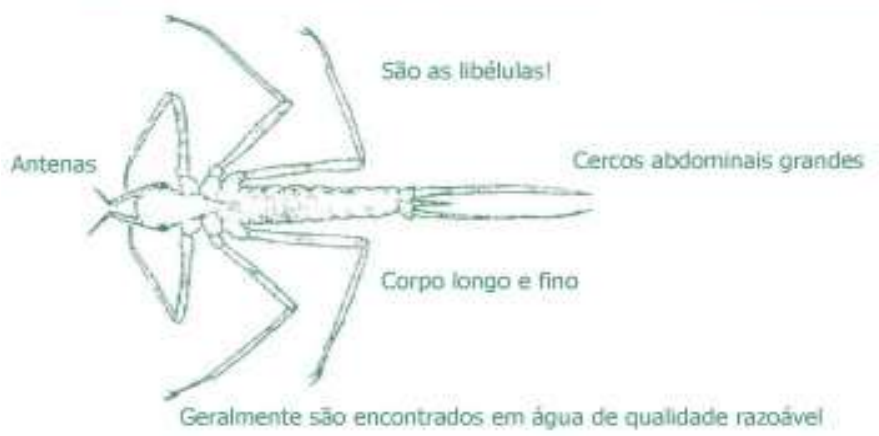

Fonte: Disponível em <https://www.embrapa.br/contandociencia/agua/-/asset_publisher/EljjNRSeHvoC/content/bioindicadoresde-qualidade-de-agua/1355746? inheritRedirect=false $>$ acesso em 19 de abril de 2019.

Figura 28 - Inseto pertencente a Ordem "Hemiptera", bioindicador de uma qualidade de água média ou regular:

HEMIPTERA

04 pontos

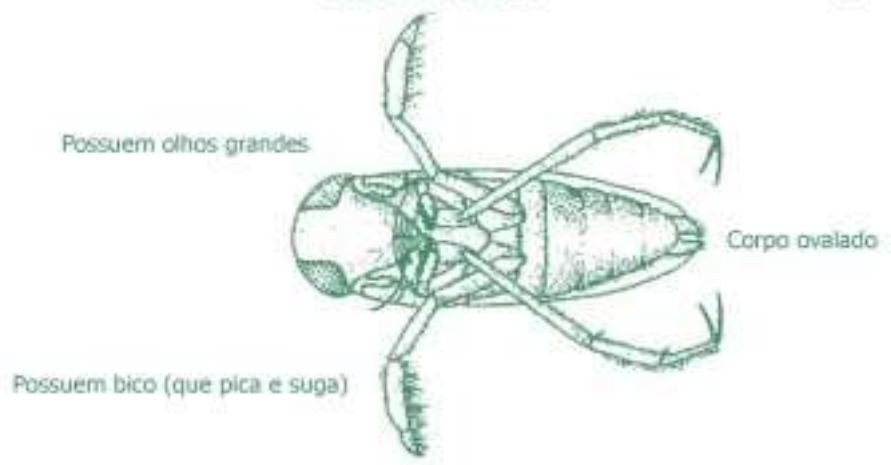

Geralmente săo encontrados em àgua de qualidade média a ruim

Fonte: Disponível em <https://www.embrapa.br/contandociencia/agua/-/asset_publisher/EljiNRSeHvoC/content/bioindicadoresde-qualidade-de-agua/1355746? inheritRedirect=false > acesso em 19 de abril de 2019. 


\section{3 - Bioindicadores de Qualidade Péssima ou Ruim de Água:}

As Figuras 29, 30, 31, 32, 33, 34, 35 e 36 caracterizam o desenho de alguns insetos $e$ animais considerados "bioindicadores", cuja a presença dos mesmos nos corpos d'agua indicam uma Qualidade de Água de Nível Péssimo ou Ruim:

Figura 29 - Inseto pertencente a Ordem "Coleoptera", bioindicador de uma qualidade de água péssima ou ruim:

\section{COLEOPTERA (Lana) 04 pontos}

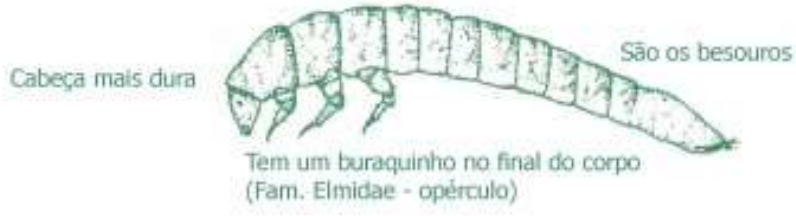

\section{COLEOPTERA (Adulto) 04 pontos}

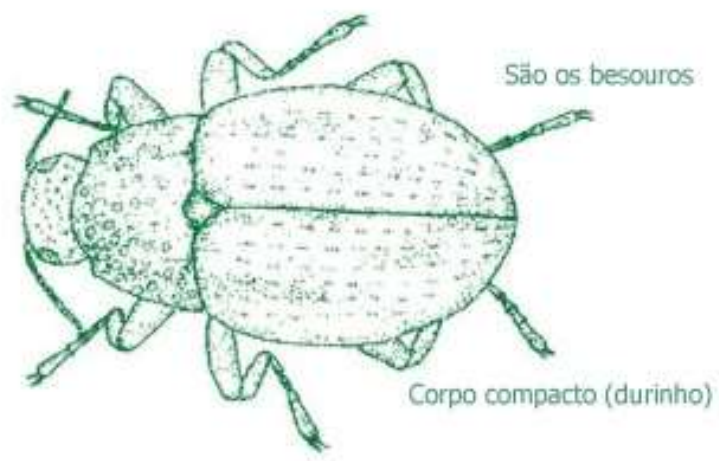

Geralmente sāo encontrados em água de qualidade ruim

Fonte: Disponível em <https://www.embrapa.br/contandociencia/agua/-/asset_publisher/EljjNRSeHvoC/content/bioindicadoresde-qualidade-de-agua/1355746?inheritRedirect=false $>$ acesso em 19 de abril de 2019. 
Figura 30 - Inseto pertencente a Ordem "Hemiptera", bioindicador de uma qualidade de água péssima ou ruim:

HEMIPTERA

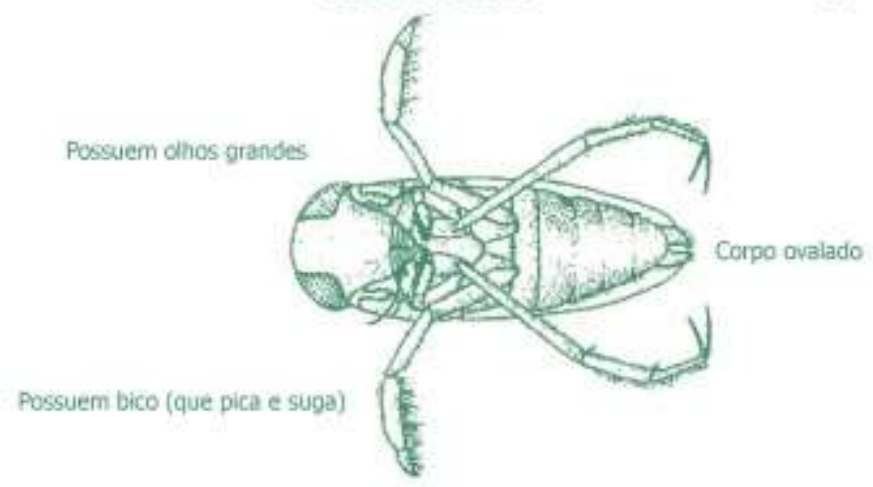

Geraimente săo encontrados emi àgua de qualidade media a ruim
04 pontos

Fonte: Disponível em <https://www.embrapa.br/contandociencia/agua/-/asset_publisher/EljiNRSeHvoC/content/bioindicadoresde-qualidade-de-agua/1355746? inheritRedirect=false > acesso em 19 de abril de 2019.

Figura 31 - Inseto pertencente a Ordem "Diptera", bioindicador de uma qualidade de água péssima ou ruim:

\section{DIPTERA Simulidae $\quad 02$ pontos}

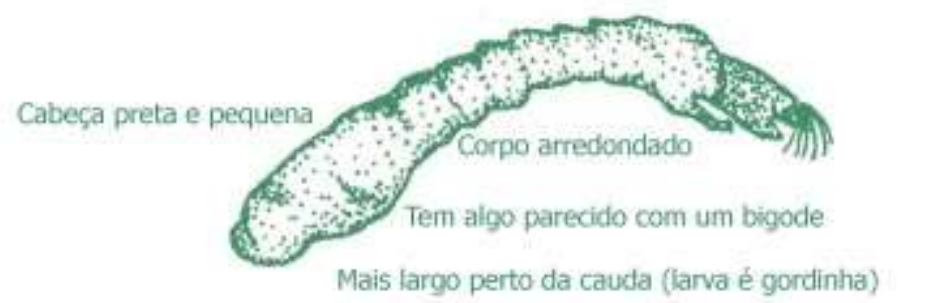

Geralmente săo encontrados em água de qualidade muito ruim

Fonte: Disponível em <https://www.embrapa.br/contandociencia/agua/-/asset_publisher/EljjNRSeHvoC/content/bioindicadoresde-qualidade-de-agua/1355746?inheritRedirect=false $>$ acesso em 19 de abril de 2019. 
Figura 32 - Inseto pertencente a Ordem "Diptera", Família "Tipulidae", bioindicador de uma qualidade de água péssima ou ruim:

\section{DIPTERA Familia Tipulidae}

02 pontos

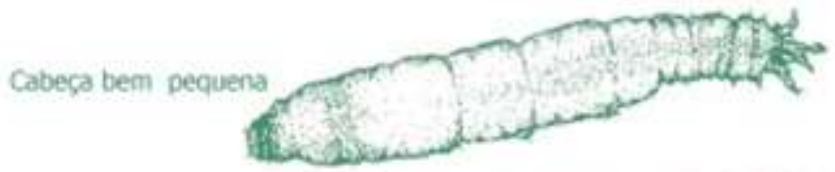

Tentáculos sensitivos na extremidade do abodome

\section{Geralmente sto encontrados em água de qualichade multo ruim}

Fonte: Disponível em <https://www.embrapa.br/contandociencia/agua/-/asset_publisher/EljjNRSeHvoC/content/bioindicadoresde-qualidade-de-agua/1355746? inheritRedirect=false $>$ acesso em 19 de abril de 2019.

Figura 33 - Inseto pertencente a Ordem "Diptera", bioindicador de uma qualidade de água péssima ou ruim:

DIPTERA Chiromidae

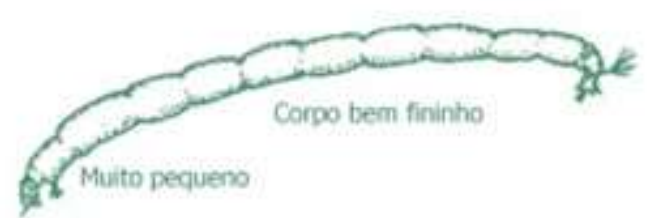

Parece possuir minúsculas patas, mas nâo șjo! É um óngäa resplratório (sif́o)

Pode ser branco, cinzento, rosa ou vermelho

\section{Geralmente shlo encontrados em doua de qualidade muito ruim}

Fonte: Disponível em <https://www.embrapa.br/contandociencia/agua/-/asset_publisher/EljjNRSeHvoC/content/bioindicadoresde-qualidade-de-agua/1355746? inheritRedirect=false > acesso em 19 de abril de 2019. 
Figura 34 - "sanguessuga", pertencente ao Filo "Annelida", bioindicador de uma qualidade de água péssima ou ruim:

HIRUDINEA 02 pontos

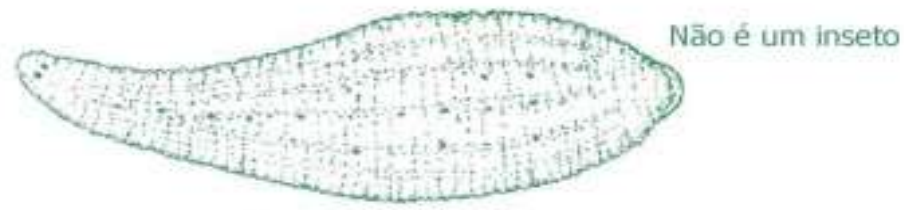

Corpo limoso e mole

Pequena ventosa no abdome, usada para sugar o sangue

São grandes; são as sanguessugas

Geralmente são encontrados em água de qualidade muito ruim

Fonte: Disponível em <https://www.embrapa.br/contandociencia/agua/-/asset_publisher/EljiNRSeHvoC/content/bioindicadoresde-qualidade-de-agua/1355746? inheritRedirect=false $>$ acesso em 19 de abril de 2019.

Figura 35 - "Molusco", pertencente ao Filo "Mollusca", bioindicador de uma qualidade de água péssima ou ruim:

MOLLUSCA

02 pontos
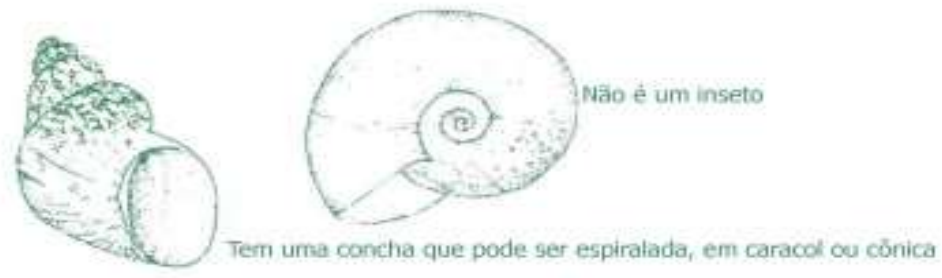

Existem pequenos, médios e grandes

Geralmente sāo encontradas em àgua de qualidade muito rum

Fonte: Disponível em <https://www.embrapa.br/contandociencia/agua/-/asset_publisher/EljiNRSeHvoC/content/bioindicadoresde-qualidade-de-agua/1355746? inheritRedirect=false > acesso em 19 de abril de 2019. 
Figura 36 - Animal "Oligochaeta", ao Filo "Annelida", bioindicador de uma qualidade de água péssima ou ruim:

\section{OLIGOCHAETA 02 pontos}

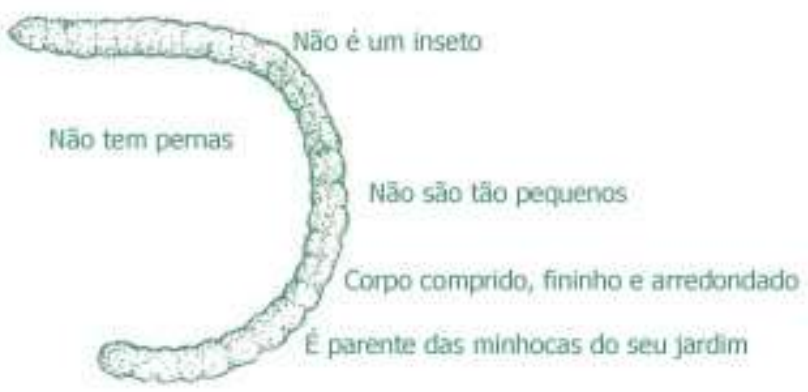

Geralmente sâo encontrados em àgua de qualidade muito ruim

Fonte: Disponível em <https://www.embrapa.br/contandociencia/agua/-/asset_publisher/EljjNRSeHvoC/content/bioindicadoresde-qualidade-de-agua/1355746? inheritRedirect=false $>$ acesso em 19 de abril de 2019. 


\section{2 - Transdisciplinaridade envolvendo temas ambientais:}

O cantor Guilherme Arantes, em sua lindíssima música "Planeta Água" afirma: "_Terra! Planeta Água"

Água que nasce na fonte serena do mundo

E que abre um profundo grotão

Água que faz inocente riacho

E deságua na corrente do ribeirão

Águas escuras dos rios

Que levam a fertilidade ao sertão

Águas que banham aldeias

E matam a sede da população

Águas que caem das pedras

No véu das cascatas, ronco de trovão

E depois dormem tranquilas

No leito dos lagos

No leito dos lagos

Água dos igarapés

Onde lara, a mãe d'água

É misteriosa canção

Água que o sol evapora

Pro céu vai embora

Virar nuvens de algodão

Gotas de água da chuva

Alegre arco-íris sobre a plantação

Gotas de água da chuva

Tão tristes, são lágrimas na inundação

Águas que movem moinhos

São as mesmas águas que encharcam o chão

E sempre voltam humildes

Pro fundo da terra

Pro fundo da terra 


\section{Terra! Planeta Água}

Terra! Planeta Água

Terra! Planeta Água

Água que nasce na fonte serena do mundo

E que abre um profundo grotão

Água que faz inocente riacho

E deságua na corrente do ribeirão

Águas escuras dos rios

Que levam a fertilidade ao sertão

Águas que banham aldeias

E matam a sede da população

Águas que movem moinhos

São as mesmas águas que encharcam o chão

E sempre voltam humildes

Pro fundo da terra

Pro fundo da terra

Terra! Planeta Água

Terra! Planeta Água

Terra! Planeta Água

Terra! Planeta Água

Terra! Planeta Água

Terra! Planeta Água 


\section{1- Atividades para a fixação do aprendizado:}

(atividade elaborada para ser trabalhada "interdisciplinarmente")

1 - Ao observar a belíssima música de autoria do grande cantor e compositor de Música Popular Brasileira, Guilherme Arantes, intitulada "Planeta Água", procure o significado de algumas palavras presentes na música:
1 - Fonte:
4 - Cascata:
2 - Grotão:
5 - Igarapé;
3 - Fertilidade:
6 - Moinho:

2 - Guilherme Arantes, na $3^{\underline{a}}$ estrofe de sua música:
"Água dos igarapés
Onde lara, a mãe d'água
É misteriosa canção"

fala sobre a figura de "lara a mãe d'água", pesquise essa figura que é descrita no folclore brasileiro, quem é, o que representa e a região que essa figura aparece.

3 - Em certo trecho da música, o cantor afirma em sua canção:

$$
\begin{gathered}
\text { “Água que o sol evapora } \\
\text { Pro céu vai embora } \\
\text { Virar nuvens de algodão" }
\end{gathered}
$$

observando o ciclo da água apresentado anteriormente, explique esse fenômeno físico.

4 - Em outro trecho da música, o cantor faz menção ao "arcoíris" explique, como ocorre o arco-íris ?

5 - Explique a diferença existente entre uma nascente, um riacho e um ribeirão e um rio . 
6 - Quais são os principais fatores que causam inundações em cidades e quais as sugestões para evitá-las ?

7 - Qual a importância do plantio de árvores para o meio ambiente?

8 - Vista do espaço nosso planeta Terra, é um ponto azul, por quê?

9 - A água potável está cada vez mais escassa no mundo, pesquise a quantidade, em porcentagem de água potável que está disponível no mundo.

10 - Verifique a quantidade de água que é utilizada na agricultura, na indústria, na recreação e para o consumo humano e .diga onde é utilizada mais a água?

11 - Diga quais maneiras existentes em residências que podem ser empregadas para o uso racional da água, quanto para o reaproveitamento da água.

12 - O que são cisternas?

13 - O que é o chamado "Aquífero Guarani" ? Por quais Estados o Aquífero Guarani passa ? e o que são os chamados pontos de recarga de um aquífero e como ele pode ser preservado?

14- Pesquise porque o óleo de cozinha (comumente conhecido como óleo de soja) deve ser recolhido adequadamente e não pode ser jogado diretamente no ralo da pia. O que ocorre ?

15 - Porque devemos utilizar produtos, (como o detergente) "biodegradáveis" ? Diga o que ocorrerá com um rio, se for utilizado anteriormente um detergente não "bio-degradável" ? Qual é a ação nociva do mesmo neste corpo d'água ? 
16 - Porque os esgotos devem ser tratados antes de serem jogados no rios ? Porque uma grande mortandade de peixes é consequência do despejo de esgoto num rio ?

17 - Pesquise sobre o rio Tamisa, que banha as cidades inglesas de Oxford e Londres e diga como era o rio antigamente com a poluição e como foi realizado o processo de despoluição deste rio e os benefícios que foram trazidos com a despoluição ?

18 - Pesquise sobre os chamados emissários submarinos de esgoto, existentes em cidades litorâneas, o que são ? Verifique se é necessário fazer algum tratamento com o esgoto antes do envio no emissário e caso seja, como é realizado esse tratamento ?

19 - Diga o que é uma hidrovia ? cite o nome de algumas hidrovias existentes e diga qual é a importância da mesma.

\section{Caça Palavras de Educação Ambiental}

No caça palavras de Educação Ambiental, procure e marque, as seguintes palavras:

$$
\begin{aligned}
& \text { sustentabilidade - terra - caatinga - bentônico } \\
& \text { folhas - sistema lêntico - cerrado - rios } \\
& \text { água - sistema lótico - Amazônia - reserva legal } \\
& \text { - natureza - árvore - consciência - pantanal } \\
& \text { fonte d'agua - bentônico - proteção - córrego } \\
& \text { proteção ambiental - bioma - estômato }
\end{aligned}
$$$$
\text { reserva ecológica - vida - mata atlântica - anfíbios }
$$ 
OBWIUFYDMNNRBJAJAJRUUIIIIIEEEEHOJEIUYTET QPQQVBNSISTEMALÊNTICOOIUEEEEVIVERUYTRT AADQDEFQWEERTTYIIAYYYEIUUURRCASAYTQRY AMEQQSISTEMA LÓTICOOIUIUUYRRREERRPUEGU OPUMUTRQRESTÔMATOYTRESKKQEWDDDIRLIXOI IIIAESYTSKKETNECSANTRESUUURWQQQQ OEEOE YYEIUYTRRSERQGBMMMÁGUAAEREMTESTYERID OVUIIIUYTTMEGALCPEIXESWEHHAEEEI3QEIUEUA ASSIAINÔZAMAKLIUYRESERVAUYYLEGALIÇOITED ASSMTTTITREARESERVAECOLÓGICAUIITIAÃAIGOI TTTIBTQERESWRODACIDNIOIBUYRTWISIIJOIITYOL EORÉPTEISICSCCPROTEÇÃOAMBIENTALIUUU7YI PTRENNCSRUONATUREZAIUQYETNNDEVIDASUIB ATRNTKIUSTYURUYUQYEYTREWRTREFREREIIIOA NFRAGNITAACUIEIOPOGALYTRIOIIUTCÓRREGOET TKGEOOIYANFÍBIOSILIÇBTREWQOOIUYTWQERDIN AGFMATAATLÂNTICAELPUUETIURFOLHASREWNE NRAILICATAMYTOUTUYTEAUYFONTED'ÀGUAITERT ARMOJUHHDGUNYUPODARRECAIRTERRAWNMFIS LTOREJVNBDKIJGERRÉEOÁRVORETERFWYTREIIU TTIIERQIIRIOSIIOIONDFEREOOBENTÔNICOTREGGS WBIITOTNEMATSEROLFERTRWCONSCIÊNCIAUTEI 


\section{3 - Entidades de credibilidade voltadas a Proteção do Meio Ambiente e dos Animais:}

Esta cartilha trás como indicações de confiança, respeito e credibilidade às seguintes entidades que lutam pela proteção do meio ambiente, das florestas e dos animais:

Entre eles estão o "Greenpeace", conforme a Figura 37, trás o símbolo desta importante organização independente sem fins lucrativos.

Figura 37 - Símbolo com as letras características do "Greenpeace":

\section{GREENPEAC}

Fonte da Imagem: "Site" "Greenpeace", Imagem disponível em $<w w w$.greenpeace.org $>$.

Também o WWF (World Wide Fund for Nature) "Fundo Mundial para a Natureza", que é uma organização apartidária e sem fins lucrativos, representada na Figura 38 abaixo:

Figura 38 - Símbolo, que trás como animal representante da organização o "panda", com as respectivas letras "WWF":

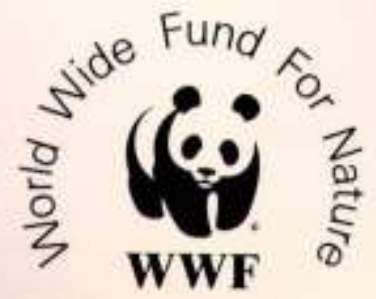

Fonte da Imagem: "Site" "ScholarshipsAds", Imagem disponível em < https://www.scholarshipsads.com/wwf-professional-developmentgrants-switzerland-2017/>. 
Outra importante organização de proteção ambiental, sem fins lucrativos, relacionada a conservação e preservação da vida marinha é a "Sea Shepherd".

Figura 39 - Símbolo da organização sem fins lucrativos "Sea Shepherd", que luta pela preservação e conservação da vida marinha em todo mundo.

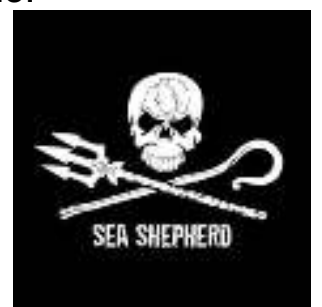

Fonte da Imagem: "Site" "Sea Sheperd", Imagem disponível em < https://seashepherd.org.br/issb/>.

Uma outra importante organização de proteção ambiental, é a "Fundação Cousteau", que foi criada pelo documentarista de vida selvagem marinha o francês Jacques-Yves Cousteau (19101997).

Figura 40 - Símbolo da "Fundação Cousteau", que luta pela preservação e conservação ambiental:

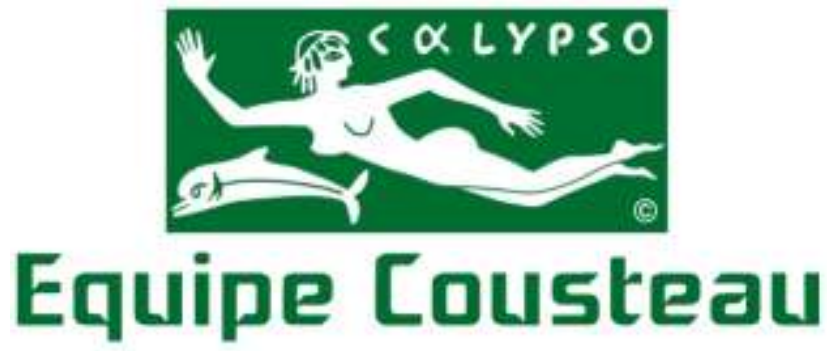

Fonte da Imagem: "Site" "Free vectors", Imagem disponível em < https://all-free-download.com/freevector/download/calypso_equipe_cousteau_133570_download.html> 
Outra importante organização de proteção ambiental, é a "Fundação SOS Mata Atlântica", que tem como característica a proteção e preservação ambientais referente a campanhas de reflorestamento e proteção da fauna nativa.

Figura 41 - Símbolo da "Fundação SOS Mata Atlântica":

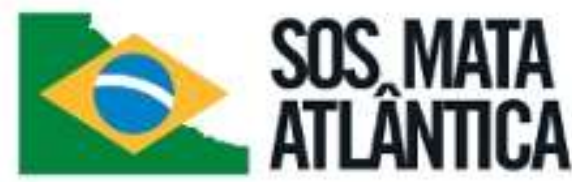

Fonte da Imagem: "site" "SOS Mata Atlântica", disponível em: $<$ https://www.sosma.org.br/noticias/licenciamento-ambiental-o-brasilnao-esta-refem/>

Afim de se levar o acesso referente a Educação Ambiental a todos como uma forma de sensibilização referente a proteção do meio ambiente do qual todos dependemos para a sobrevivência de nós mesmos, de nossos filhos e das futuras gerações, a presente cartilha de educação não pode ser comercializada. 


\section{4 - Referências:}

A importância do reflorestamento nas margens e nascentes dos rios. Disponível em <e>, acesso em 19 de abril de 2019.

Bioindicadores,

Disponível

em

<https://www.embrapa.br/contando-ciencia/agua/-

/asset_publisher/EljjNRSeHvoC/content/bioindicadores-dequalidade-de-agua/1355746? inheritRedirect=false $>$ acesso em 19 de abril de 2019.

CALLISTO, Marcos; BARBOSA, Francisco A. R.; RIETZLER, Arnola C.; BARBOSA, Paulina M. Maia; FERREIRA, Rosa Maria. Bioindicadores de qualidade de água, Minas Gerais: Universidade Federal de Minas Gerais, UFMG, Instituto de Ciências Biológicas, Departamento de Biologia Geral, Laboratório Limnologia/Ecologia Bentos. Cartilha. 19 p.

Espécies Exóticas Invasoras: Disponível em <http://www.mma.gov.br/biodiversidade/conservacao-deespecies/especies-exoticas-invasoras.html>, acesso em 20 de abril de 2019.

Espécies Exóticas Invasoras. Disponível em $<$ https://www.oeco.org.br/dicionario-ambiental/28434-o-que-euma-especie-exotica-e-uma-exotica-invasora/>, acesso em 20 de abril de 2019.

\section{Hidatódios:}

BIANCHI, Sandra. Tecidos vegetais ou histologia, Slide, Disponível em <https://slideplayer.com.br/slide/11130653/> acesso em 19 de abril de 2019. 
Hidatódios,

Slide

Disponível

em

<https://deskgram.net/explore/tags/guta\%C3\%A7\%C3\%A3 o>, acesso em 20 de abril de 2019.

MAGOSSI, Luiz Roberto; BONACELLA, Paulo Henrique. Poluição das águas. São Paulo: Editora Moderna, 1996. 56p.

Monitoramento da qualidade da água em rios e reservatórios. Brasília: Agência Nacional de Águas, 2019. Curso EaD de capacitação, 40 horas. Disponível em <https://capacitacao.ead.unesp.br/index.php/temas/65hidrologia-e-qualidade-da-agua/146-monitoramento-daqualidade-da-agua-em-rios-e-reservatorios $>$ acesso em 01 de março de 2019.

O caminho das águas. Brasília: Agência Nacional de Águas, 2019. Curso EaD de capacitação, 30 horas. Disponível em < https://capacitacao.ead.unesp.br/index.php/temas/71-educacaocapacitacao/108-caminho-das-aguas > acesso em 01 de fevereiro de 2019.

PETRIN, Natalia. Transpiração vegetal. Artigo publicado na Internet em 20/04/2015, atualizado em 21/04/2015, Disponível em $<$ https://www.estudopratico.com.br/transpiracao-vegetalcuticular-e-estomatica/>, acesso em 20 de abril de 2019.

PRIMACK, Richard. B.; RODRIGUES, Efrain. Biologia da conservação. Londrina: E. Rodrigues, 2001.

Relação entre as árvores e a qualidade das águas. Disponível em <https://www.juntospelaagua.com.br/2016/12/08/relacaoarvore-e-agua/>, acesso em 19 de abril de 2019.

Resolução Conama no 275, de 25 de abril de 2001, que estabelece o código de cores para os diferentes tipos de resíduos, 
a ser adotado na identificação de coletores e transportadores, bem como nas campanhas informativas para a coleta seletiva.

Respiração e Transpiração nos vegetais: Disponível em < https://escolakids.uol.com.br/ciencias/respiracao-e-transpiracaonos-vegetais.htm >, acesso em 20 de abril de 2019.

RODRIGUES, Ricardo Ribeiro; FILHO, Hermógenes de Freitas Leitão. Matas ciliares: conservação e recuperação. 2를 Edção e $2^{a}$ Reimpressão. São Paulo: Editora Universidade de São Paulo, Fapesp, 2009.

SAUVAIN, Philip. Rios e vales. Traduzido do Título Original "Rivers and valleys" por Antivan Guimarães Mendes. São Paulo: Editora Scipione, 1998.

"site" "SOS Mata Atlântica", disponível em: $<$ https://www.sosma.org.br/noticias/licenciamento-ambiental-obrasil-nao-esta-refem/>

Tamanho das Áreas de Preservação Permanentes APP's Disponível em <http://inteliagro.com.br/quanto-deve-medir-umaapp-area-de-preservacao-permanente-de-um-rio/>, acesso em 20 de abril de 2019.

TAUK-TORNISIELO, Sâmia Maria; GOBBI, Nivar; FOWLER, Harold Gordon. Análise ambiental: uma visão multidisciplinar. $2^{2}$ Edição revisada e ampliada, São Paulo: Editora da UNESP, 1995.

Tempo de Degradação de Materiais, Disponível em $<$ http://www.fec.unicamp.br/ crsfec/tempo degrada.html> acesso em 19 de abril de 2019. 
TEIXEIRA, Cristianny Villela; SANTOS, Devanir Garcia dos; ENGEL, Diana Wahrendorff; HESSEN, Érica de Castro; CARVALHO, Flavio Herminio de, CARDOSO, Herbert Eugênio de Araujo; MAZZOLA, Marcelo; COSTA, Marcelo Pires da; LIBÂNIO, Paulo Augusto C.; GENERINO, Regina Coeli Montenegro; MELO, Vivyanne Graça de; PALANIAPPAN, Meena; GLEICK, Peter H.; ALLEN, Lucy; COHEN, Michael J.; CHRISTIAN-SMITH, Juliet; SMITH, Courtney. Cuidando das águas - soluções para melhorar a qualidade dos recursos hídricos. Agência Nacional de Águas; Programa das Nações Unidas para o Meio Ambiente. Brasília: ANA, 2011.

TUCCI, Carlos Eduardo Morelli. Hidrologia: ciência e aplicação. 1ํㅡㄹ Edição, São Paulo: EDUSP - Editora Universidade de São Paulo, 1993. 